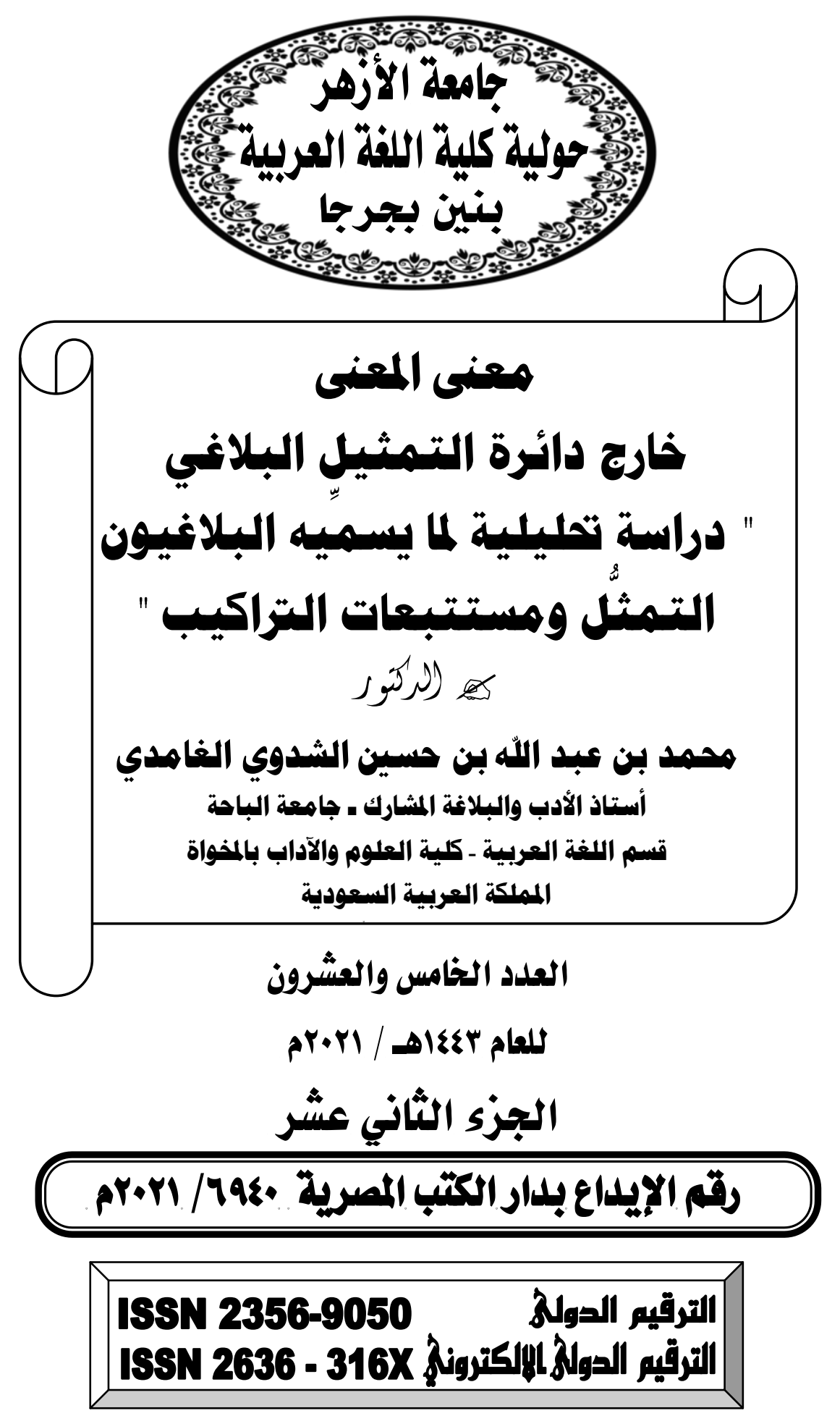


معنى المعنى خارج دائرة التمثيل البلاغي

( دراسة تحليلية لما يسقيّيه البلاغيون التمثئل ومستتبعات التزاكيب )

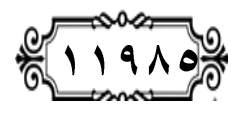

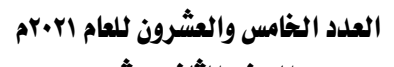

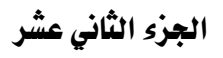

\section{بـ بـ}

\section{همنى المعنى خارج دائرة التمثيل البلاغي}

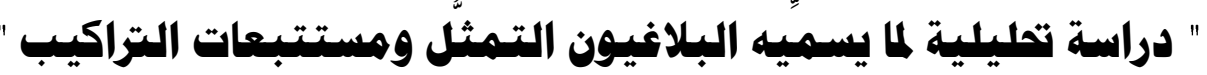

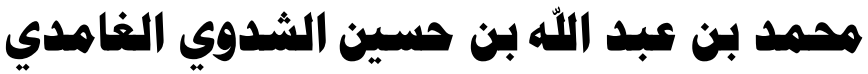

قسم الأدب والبلاغة ـ جاهعة الباحة ـ قسم اللغة العربية ـ كلية العلوم والآداب بالمخواة ـ المملكة العربية السعودية

m.3.algh@gmail.com : البريد الإلكتروني

טतil|

من الخطأ أن نرفض الالالة الحرفية للشعر لنقرض عليه دلالات نتوهمها ؛ لندخله

في دائرة التمثيل البلاغي أو معنى المعنى في باب المجاز ات والكنايات . فالالالة الحرفية للشعر قد تحمل وراعها معاني بعيدة ، أو قريبة أوسع من المجازات والكنايات ، ولا ضير أن تكون وراعها بمسافات أبعد ، أو أن تكون في باب مستتبعات التراكيب ، أو ما يسميه البلاغيون " التمثلّ " ، ويقوم هذا الباب الجليل من ون البلاغة العزبية على انتزاع الثعر من دوائر السياق ، ونفض بعض دلالاته ، و إصباغ دلالات جديدة عليه ، والخروج بالمعاني إلى مساحات أوسع وفضاءات أشمل مما هي عليه في التمثيل البلاغي مهن والتمثُّ يقوم على نفض بعض دلالات الشعر ، وإصباغ دلالات جديدة عليه حيث يتم إهمال الالالات المرادة وجعل ذللك كله إثارات يتولا عنها هاجس" جديا لم يتولا

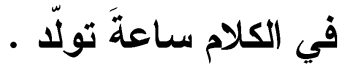

ومن جهة أخرى قد نجد التفرُع من المعنى الحرفي إلى المعنى التمثيلي ، وبهذا تكون العملية تبادلية عكسية بين التمثلّ ومستتبعات التر اكيب والتمثيل ، وهذه العملية تولِّ دينامية دلالية تجعل من النص الشعري نصلّا تفاعليَّا بكل ما تعنيه الكلمة من معنى

الكلمات الافتاحية : التمثُّل ، مستثبعات التراكيب ، معنى المعنى ، دائرة التمثيل البلاغي . - الاغيل

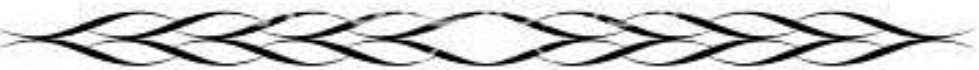


The meaning of meaning outside the circle of rhetorical representation An Analytical Study of What

Rhetoricians Call Representation

Mohammed Abdullah Hussain Alshadwi Alghamdi

Associate Professor of Arabic and Rhetoric at Albaha University Department of the Arabic language Almakhwah College of Sciences and Arts , Kingdom Saudi Arabia.

Email: m.3.algh@gmail.com

Abstract

It is a mistake to reject the literal connotation of poetry to impose upon it connotations that we delude. Let us put it in the circle of rhetorical representation or the meaning of meaning in the section of metaphors and metaphors.

On the other hand, we may find the branching from the literal meaning to the representational meaning, and in this way the reciprocal process is reversed between assimilation and representation, and this process generates a semantic dynamic that makes the poetic text an interactive text in the full sense of the word.

Keywords: Representation, the implications of structures, the meaning of the meaning, the circle of rhetorical representation. 
ביن

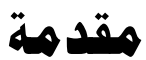

الحمد لله رب العالمين ، والصلاة والسلام على سيد المرسلين ، وإمام المثقين ، سيدنا محمد وعلى آله وأصحابه ومن سار على هديه إلـى يــوم

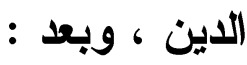

جاعت هذه الار اسة بعنوان : معنى المعنى خارج دائرة التمثيل البلاغي

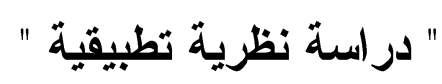
وفيها :

أهـميسة الإوضوع : نظرًا لما يظنه بعض الدارســين والمهتمـين بالشعر العربي من أن المعنى الحرفي للشعر أو ما بسميه البلاغيون بالتمثٌّ

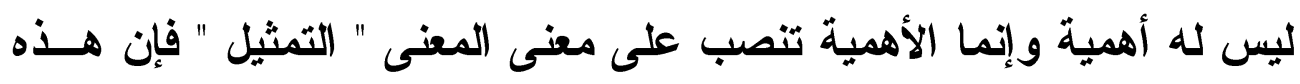
الار اسة ستبحث في التمثل في الثعر وهو بــاب أوســع مــن المجــاز ات والكنايات ، وهو باب الإثار ات التي قد تكون قريبة وقد تكون بعيدة ، ويقوم

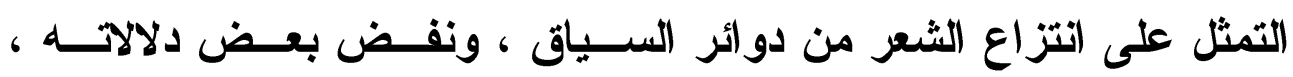

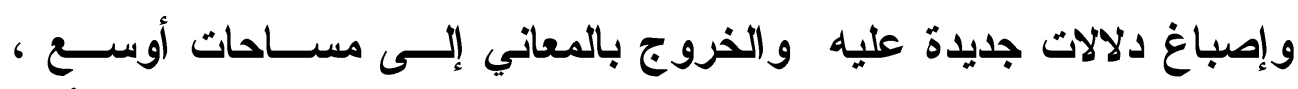

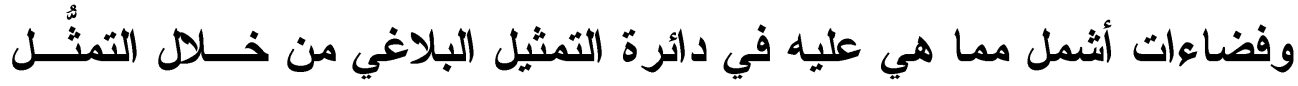
ومستتبعات التر اكيب . م

• أسبـاب اختيار الموضهوع : الرغبة في كثف باب بلاغـي جميـلـ يسمى التمثُّ ومستتبعات التر اكيب وهو باب جليل لا يقل أهمية في البلاغــة العربية عن باب التمثيل البلاغي 
•) هدف البحث : يهدف هذا البحث إلى دراسة ما يسميه البلاغيون

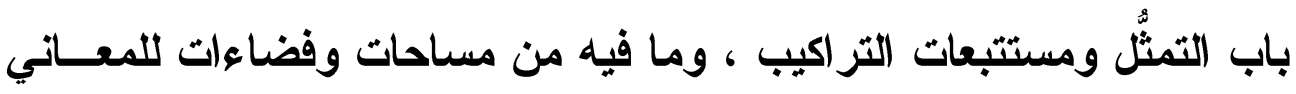

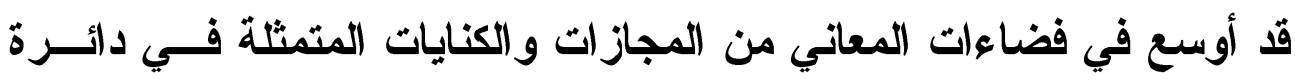

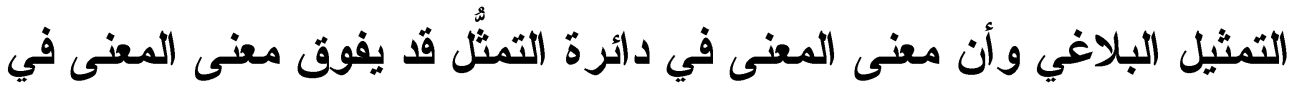
دائرة التمثيل البلاغي المعروف .

• منهج البحث : اعتمدت الدراسة على المنهج النظري التطبيقي

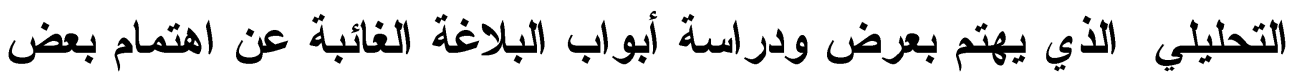

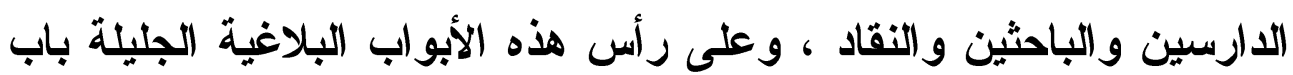

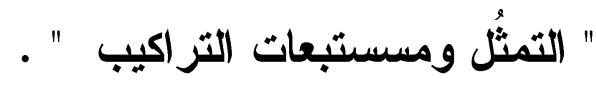

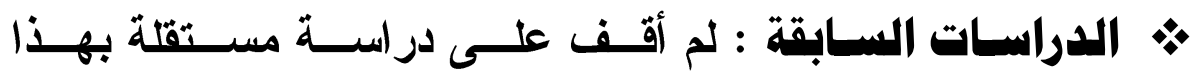
الموضوع، وإنما وققت على بعض الإثدارات من بعض الباحثين مثل :

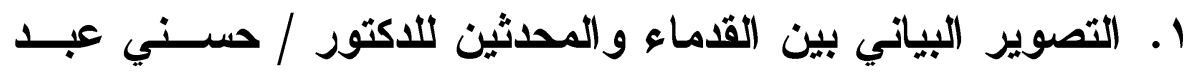
الجليل يوسف .طبعة : دار الآفاق العربية بالقاهرة ( د ، ت ) . r. ب. مفاهيم نقدية ، رينيه ويلك ، الكويت ، عالم المعرفــة ، مطــابع

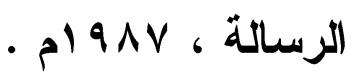

r. قراعة في الأدب القديم ، لثيخ البلاغيين محمـــ أبــي موسـى ،

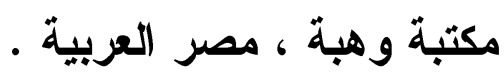

؛. التحرير والتنوير (تفسير (ابن عاثشور ) ، الدار التونسية للنشـر ،

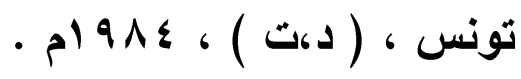

\section{0}




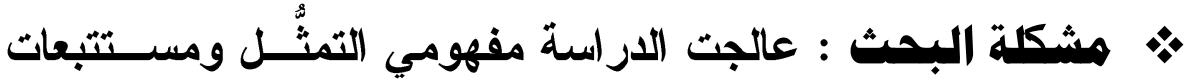

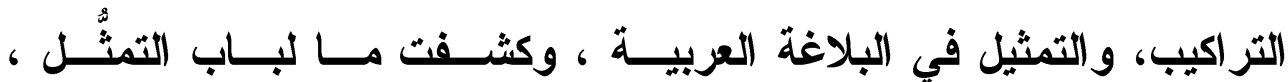
ومستتبعات التر اكيب من فضاءات واسعة تفوق فضـــاءات دوائـــر التمثيــل البلاغي، وإثبات تآزر دائرتي التمثل والتمثيل في تكوين المعاني وتصويرها.

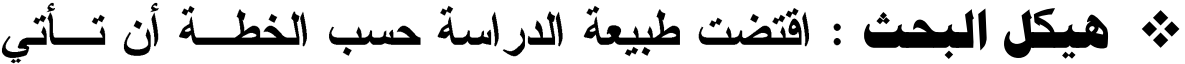
على مبحثين المبحث الأول منهما تناول : الشعر بين الحدث والحديث وفيه : محاولة للإجابة عن بعض التساؤلات مثل : هل الشعر حدث أو حــديث ؟ وهل الشعر يجب أن يطابث الواقع أو أنه حالة خاصة مخالفة له ؟ مـــا هــو باب دائرة التمثُّ ؟ وما هو باب دائرة التمثيل ؟ وما الفرق بينهما ؟ وأيهمـــا أوسع ، وأكثر توليدًا للالالات الجديدة للمعاني والخروج بها إلـى مســاحات أوسع ، وفضاءعات أشمل ؛

والمبحث الثـاني : التصوير بين دائرتي التمثُّل اللغــوي ، ودائـرة التمثيل البلاغي ، وفيه تحاول الدراسة الإجابة عن أسئلة من أهمها : لماذا

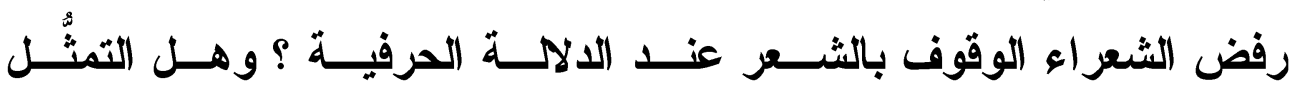
ومستتبعات التر اكيب تدخل في باب التصوير عند البلاغيين ؟ و هـل يمكـن لائرتي التمثل ومستتبعات التراكيب ، والتمثيل البلاغـي أن يتقاطعــا فـي

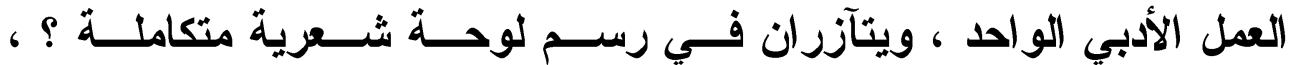
وتسبقهما مقدمة ، وتليهما خاتمة تحوي أهم النتائج والتوصيات . 


\section{المبحث الأول}

\section{الثمر بين المدث والعديثث .}

في هذا المبحث تحاول الاراسة أن تجيب عن أسئلة مهمة من أبرزها :

$$
\text { - - ما هو الخطاب الأدبي ؟ الثعر حدث أو حديث ؟ }
$$

- هل الثعر يجب أن يطابق الواقع أو أنه حالة خاصة مخالفة ؟

$$
\text { - ما المقصود بالتصوير عند علماء اللغة و البلاغة ؟ }
$$

- ما المقصود بكلٍٍ من : التمثُّل ومستتبعات التزر اكيب ، والتمثيل

$$
\text { في البلاغة العربية ؟ }
$$

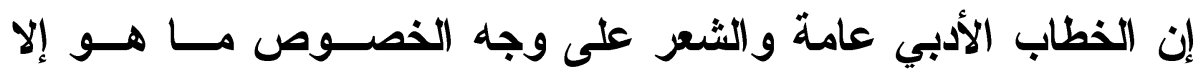

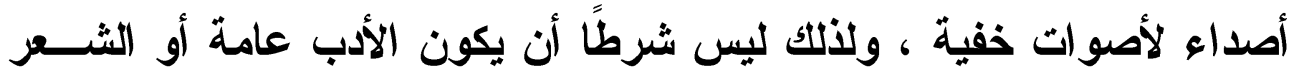

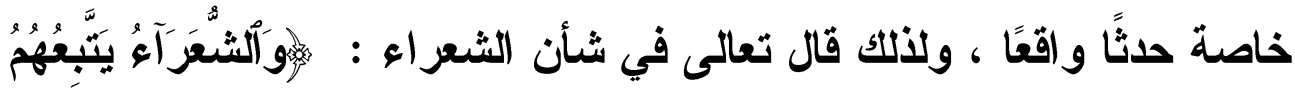

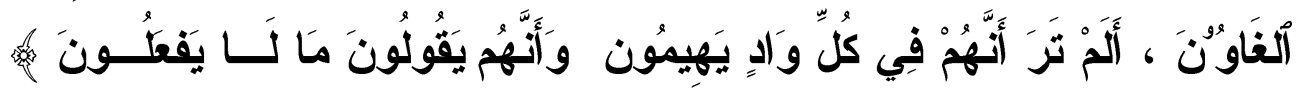

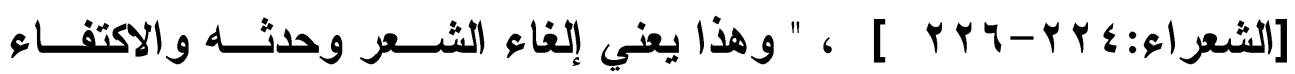

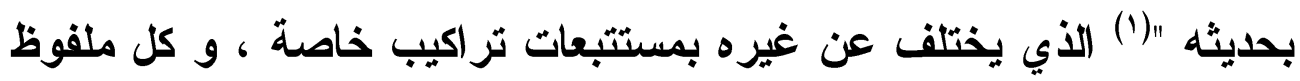

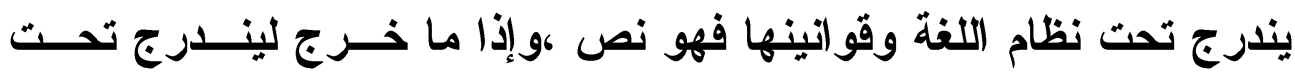
السياقات الاجتماعية سمي خطابا فالخطاب إذن يضـــلع بمهـــة توصـيل

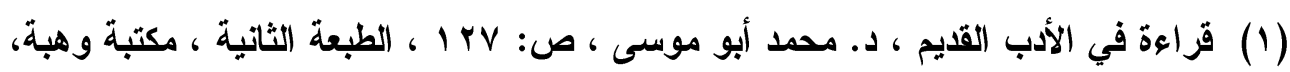

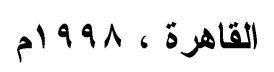


معنى المعنى خارج دائرة التمثيل البلاغي

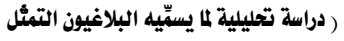

ومستتبعات التراكيب )

رسالة، ومن ثم فهو مغمور في الأيديولوجيا ، ومبالغ في خرق النظام بحثا • عن المرجع

إن الخطاب الأدبي من طبيعته، بل من شروط أدبيته ان يجعل الأثثياء المألوفة تبدو وكأنها غير مألوفة . الادي من طيفة

إن الخطاب في التعريف البلاغي العام هو "مجموعة من الجمل منطوقة

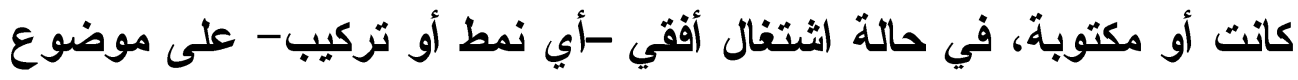

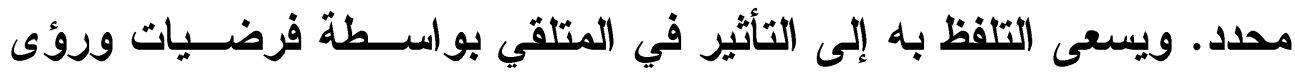
وأحاسيس، مما يتطلب مبلئيا ديمومة في إنتاجه وتلقيــه وتماســـا داخليــا

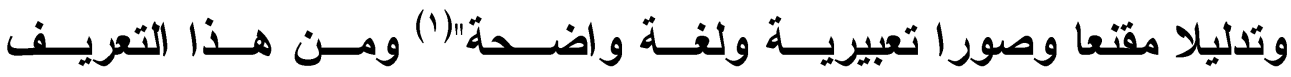

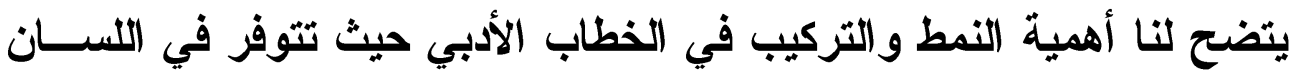

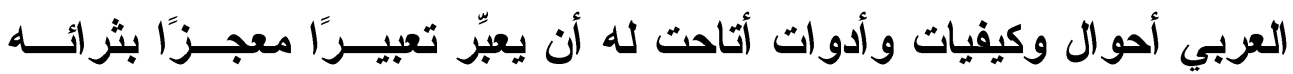

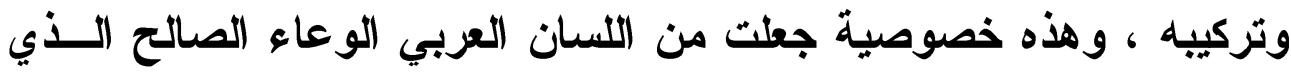
يحمل بلاغة القرآن المعزز المتعلقة بهذه الأحــوال و الكيفيـات والأدوات ،

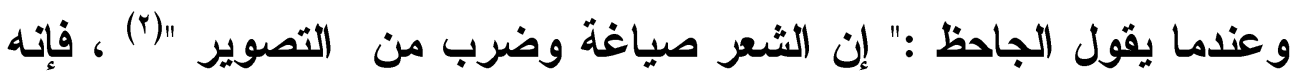
لا يقصد صياغة الألفاظ ، و إنما صياغة الأفكار والخواطر و المشــاعر ، وأن

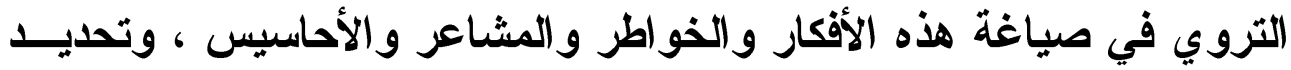

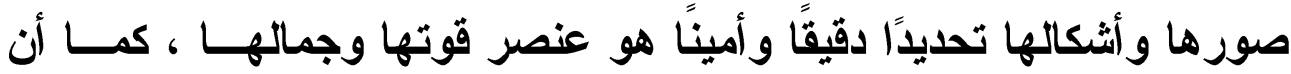
التصوير في كلام الجاحظ وغيره من العلماء القدماء لا يعني تصوير التشبيه

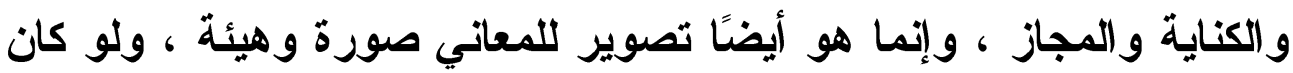

(1) النص الأدبي من الإتتاج إلى التلقي، رشيد بنداو ، أطروحة بكلية الآداب ظهـر المهـراز

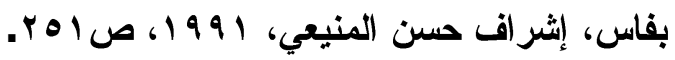

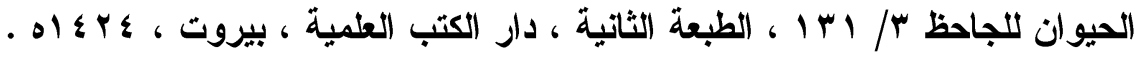

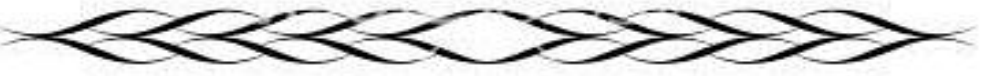




\section{الترقير الدولخ 2356-9050

ذللك بطريق الحقيقة والواقع لأن " الأي ينهض في الحقيقة بتصوير المعنـى وتثكيله هو الهيئات والأحوال و الكيفيات"(1').

وبهذا يكون معنى التصوير عند الجاحظ ومن جاء بعده من العلمــاء إنما هو " ولآدا التصرف الأكي والواعي في الكيفيات والأحــوال والعلاقـات هي التي تجري في الأدب ، وتبعث فيه الحياة والرحابة والثراء ، وهي التي

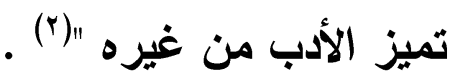

إن الخصائص والكيفيات ، ودر اسة مستتبعات التر اكيب فـي الخطــاب الأدبي تؤدي وظائفها في الإبانة ، وإن تذوق الخطاب الأدبي وتحليالـهـ مــن خلال تلاك المسستبعات والتراكيب في سياقها الفسـيح يعيــدنا إلــى جــادة الصواب فيما كان عليه علماؤنا و أدباؤنا في تحليـلـل وتــذوق النصــوص الأدبية.

إن هذا المنهج التحليلي الأي غقل عنه كثير من نقاد العصر الحديث بقصد أو غير قصد - يعينتا على الاهتداء بأحوال اللسان وطر ائـق الأداء ، وفتح نوافذ خفية تحدد لنا بواعث القول الأدبي ومثيرات المعاناة فيه ، كمــا أن دراسة علاقات المعاني ، وطريقة تكوينها ، وبيان الروابط التـي بـين الجزئيات المكونة للنص الأدبي هي الأقرب إلى طبيعة العمل الفتي ، ويتبـع ذلتك دراسة أحوال المعاني الجزئية وتركيبها ، كما أن تلك العلاقات والروابط هي التي تربط بين أجزاء النص الأدبي ، وإقامة بنائه الفني البديع ، وهـــه الار اسة تركز على دراسة الخطاب الأدبي وتحليله بعيدًا شيئًا ما عن الدوائر

$$
\begin{aligned}
& \text { (1) قراءة في الأدب القديم ، ص : بr } \\
& \text { السابق ، ص : r r r }
\end{aligned}
$$

\section{0}


معنى المعنى خارج دائرة التمثيل البلاغي

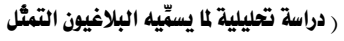
ومستتبعات التراكيب )

البلاغية الأكية لمعنى المعنى " التمثيل " حيث ستكثف الدراسة أن هناكل بابًا

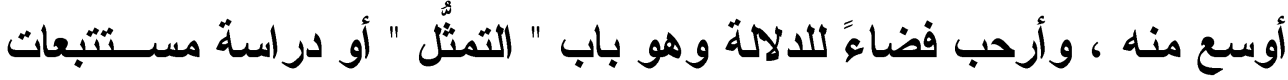

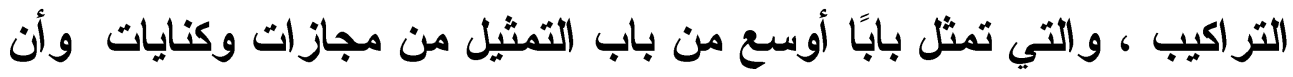

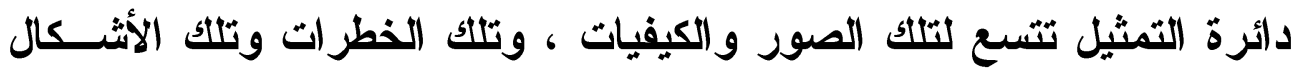

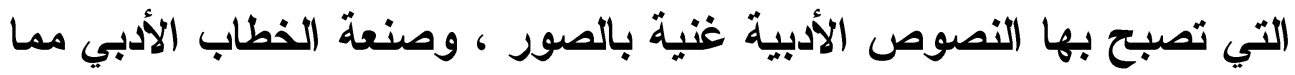

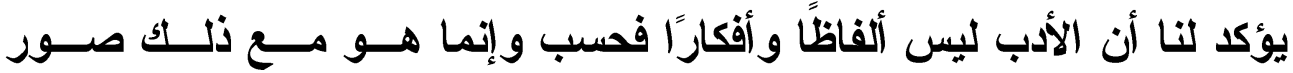

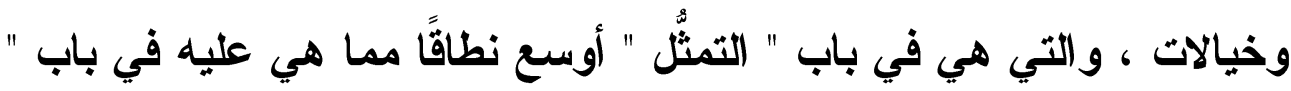

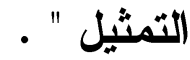

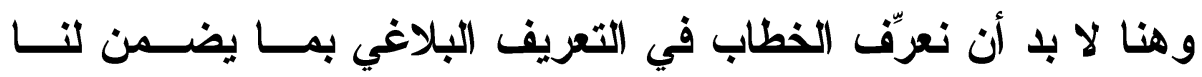
تضافر بابي التمثل والتمثيل وضرورة دراستهما جنبًا إلى جنب إذا أردنا فعلاً

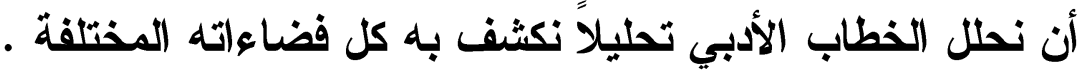
إن الخطاب في التعريف البلاغي العام هو "مجموعة من الجمل منطوقة

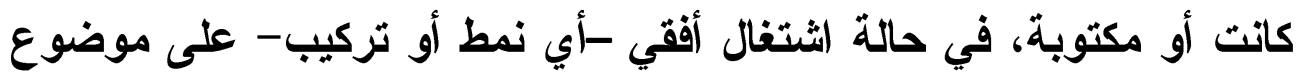

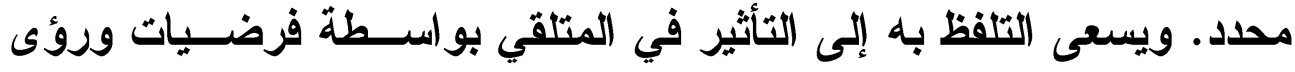

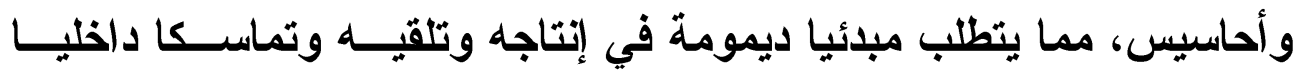
وتدليلا مقنعا وصور ا تعبيرية ولغة و واضحة." (') ولا غرابة فإجراء تحليل الخطاب مشروع مغر لكثير مـن الدارسـين

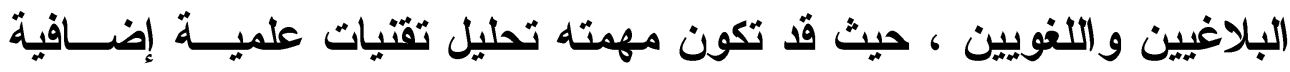

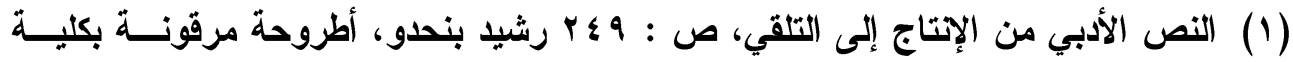

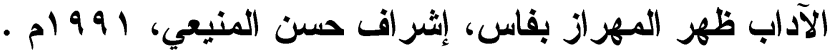

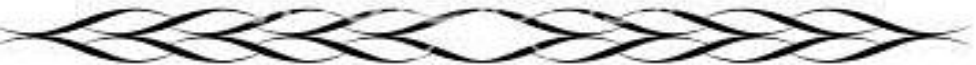


تتيح للمحلل اللغوي أو البلاغي تحصيل نتائج شكلية لها قابليــة اسـتعمال موسع مفيد في مجالات غير لغوية أيضًا.

ولا بـ لمحلل هذا المستوى من التـاول اللغوي للخطاب مـن التــزود

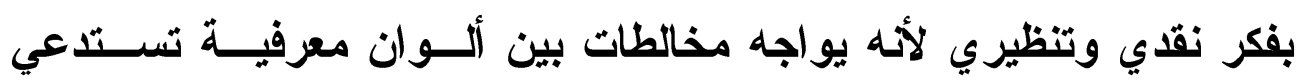

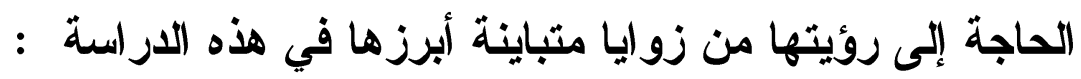

• من زاوية الخطاب "المحضر" باعتباره نقطــة انتثـــار مركزيـــة لأن تعدده الدلالي يجعل مداولته مكمن صعوبات يتعذر التحكم فيه.

$$
\text { • من زاويته كمعطى كمعرفي- إدراكي شمولي. }
$$

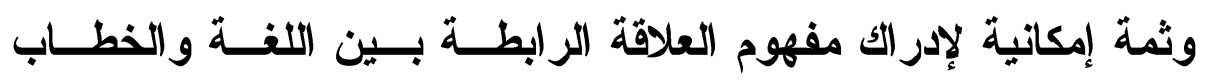

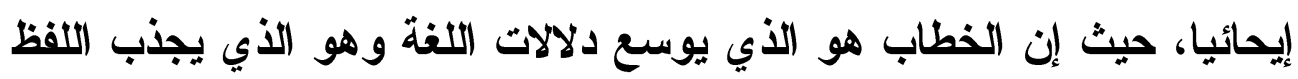

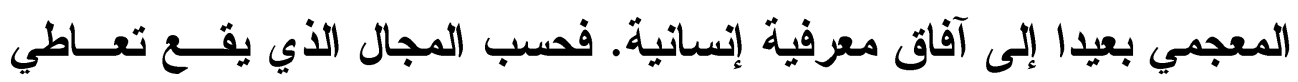

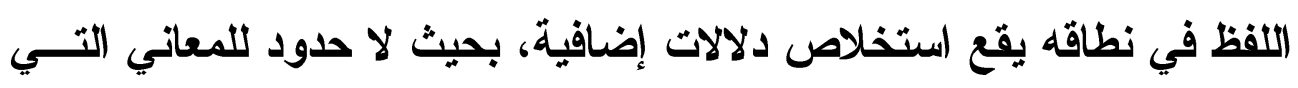
يمكن للفظ تأديتها فاللفظ يكون محاصر ا باستعمالين هما : • استعمال تقريزي : مقيد بمعنى واحد ثابت (دلالته الأساسية) ويمثـل الوضع الحيادي للغة.

• استعمال إيحائي : مفتوح يؤدي إلى إنتاج دلالات ملحقة ، وفضاءات

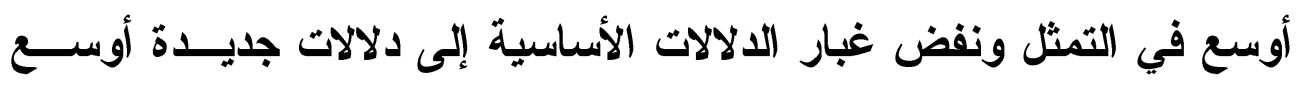
وأرحب مما هو عليه الحال في دائرة التمثيل .

وهنا تجدر الإشارة إلى مصطلح "المحاكاة " الأي عالج موقـف الأدب

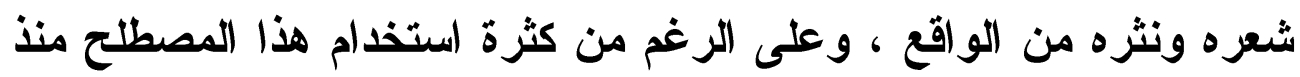

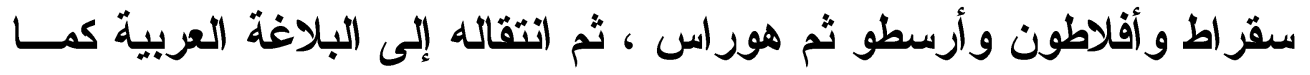


هو الحال عند حازم القرطاجني الذي يرى أن المحاكاة في الثعر " متصورة بحسن هيئة تأليف الكلام ، أو قوة صدقه ، أو قوة شهرته ، وكل ذلك يتأكد

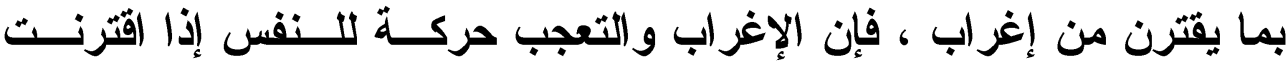

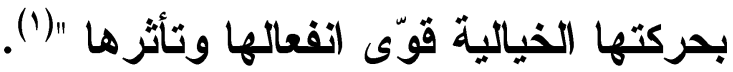

فهذا الحسن البصري في خطبه ومواعظه يتمثل بقول الثاعر(†):

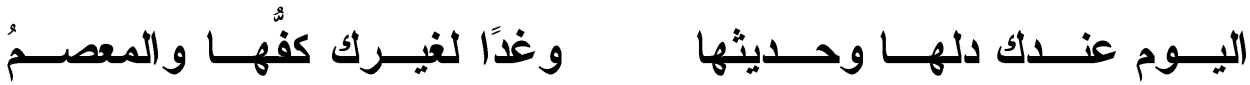
والبيت السابق كما لا يخفي قيل في النساء ، ولكن الحسن البصـــــي نفض عنه غبار الدالات الأصلية ، وألبسه بالتمثل دلالات جديدة حيث نقــل

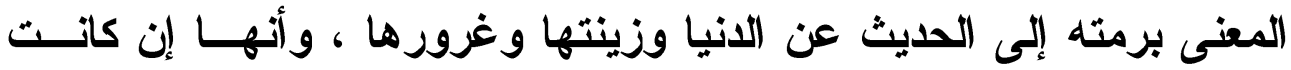

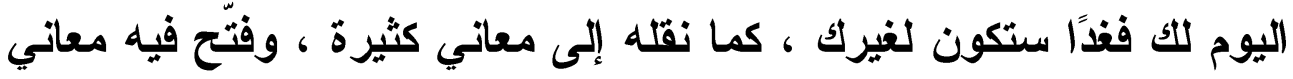

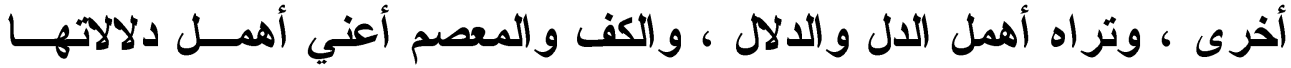

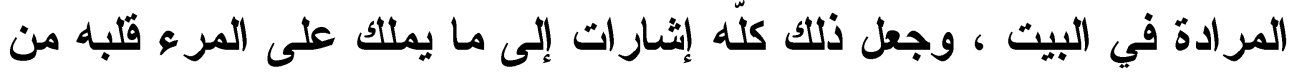
دنيا أو جاه أو مال أو ولد أو ما شئت من هاجس لم يتولد في الكلام ســاعة

وبهذا تكون المحاكاة في باب التمثيل مصطلحًا يحمل أفهــارًا جديــدة " وغالبًا ما يفسر مفهوم المحاكاة في تاريخ النقد الأدبي على أنه مرادف للنقل

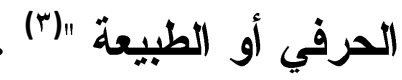

(1) تقريب منهاج البلغاء وسر اج الأدباء ، ص: .1-1 ، ، تحقيق : محمد أبو موسى ، مكتبة

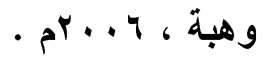

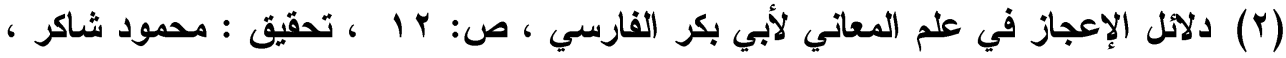

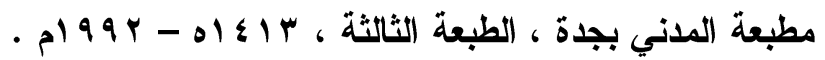

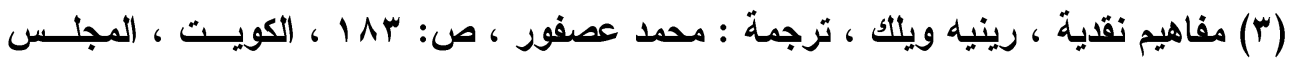

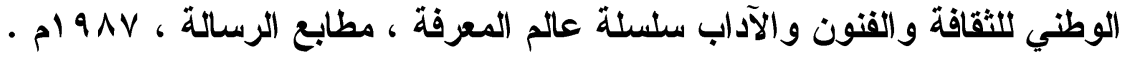


وبالنظر إلى النقد العربي نجد أن الفلاسفة العرب قـــ جمعـوا بــين مصطلحين هما : المحاكاة والتخييل . أما المحاكاة فقد عرفناها ، وأما التخيــل فهــو :" حضــور الأثــياء

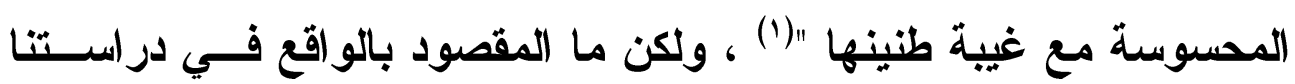
هذه

يتفق النقاد عربًا وعجمًا على أن الفن ، ومنهـ الأدب شــعره ونثــره ، والشعز على وجه الخصوص ما هو إلا محاكاة للواقع وللطبيعـة ، ولكــنهم يختلفون في طبيعة هذه المحاكاة و أساليبها .

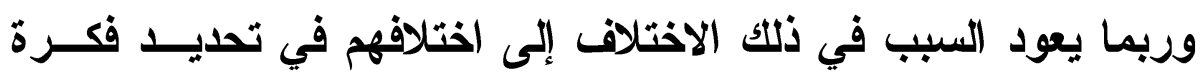

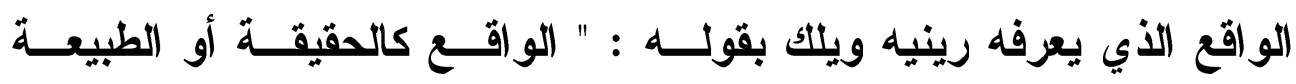
أو الحياة ، هو في الفن كما في القلسفة والاستعمال اليومي ، كلمة مشحونة

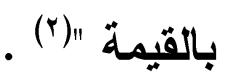

ونستتنج مما سبث أن الواقع أو الحقيقة ما هما إلا شكل مــن اثــكال

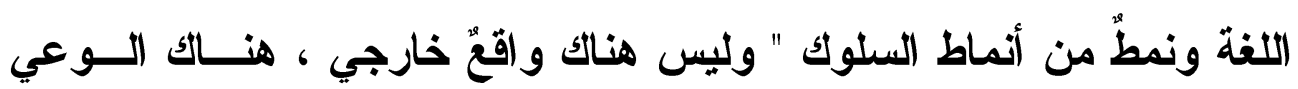
الإنساني فقط الأي يبني على الدوام عوالم جديدة "(ז) ، ومن هنا يمكن القول بأن الخيال والأدب هو مظهر للوعي الإنساني تجاه الواقع •

(1) الصورة في الثعر العربي حتى القرن الثاني الهجري دراسة في أصــولها وتطورهـا ، د.

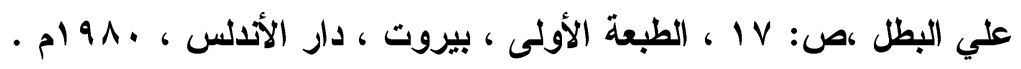

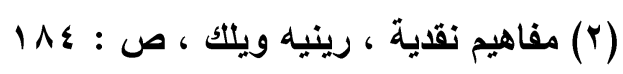

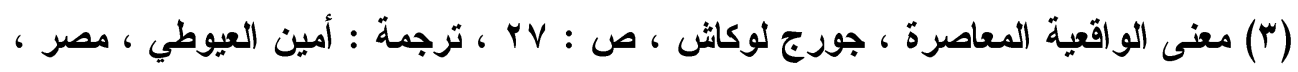

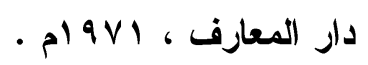


إن النص الأدبي عبارة عن تشكيلات لا نهائية من القراعة التي تقــوم عليها البنية الاجتماعية للمرحلة الزمنية عبر العصور لينتقل الـنص مسن عصر إلى عصر مفاهيم جديدة ناتجة عن القدرة الكامنة والمشــونة في اللغة ، وهذا يكمن في دائرة "التمثُّل

أما دائرة التمثيل القائمة على المجاز والاستعارة والتشبيه فإنها ليست ببعيدة عن دائرة التمثل حيث إن أنـــواع دائـــرة التمثيـل مـــن اســتعار ات وتثبيهات تصنّف أيضًا عل مدى مطابقة المجاز للاعقل والمنطــق ، وكـــلك التمييز بين المادي والمعنوي ، ويضع فيها البلاغيون فيها اعثقاد الســـامع والمتلقي مقياسًا لمطابقة الكلام للو اقع • وقد تدرك فنون التمثيل البلاغي بالحواس غير أن فرسًا كفرس امرئ القيس ، أو ناقة كناقة الأعشى لا يمكن إدراكهما إلا بالعقل والتأمل المــــمم بالو اقع رغم أنه لا يشابهه شيع منه فعندما يقول امرؤ القيس(') :

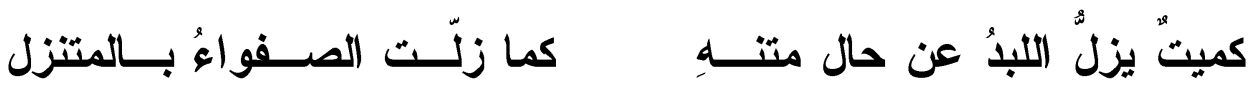

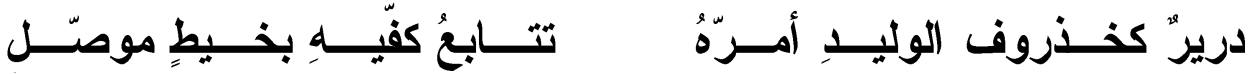

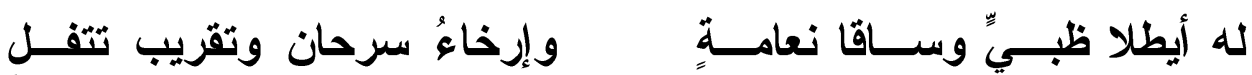
ثم يقول بعد ذلك : مئ

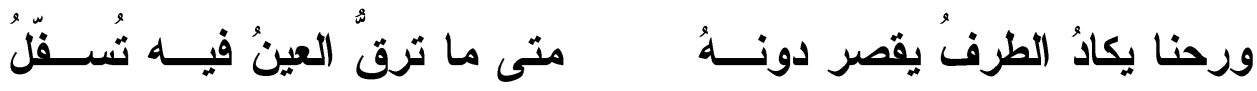
(1) ديوان امرئ القيس ، ص : צ ؛-1 ؛ ، تحقيق وشرح : حنّا فاخوري ، الطبعة الأوكسى ،

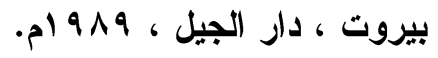


فإنه يكثف لنا أن العين عاجزة عن تأمل أوصاف فرسه ؛ لأنه فــوق

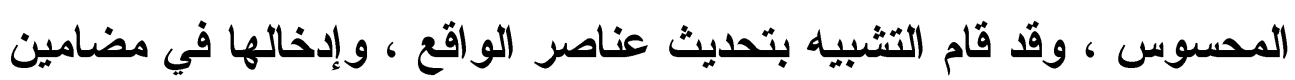
جديدة تُدرك بالعقل و التأمل .

إن الصورة الفنية في دائرة التمثيل تمثلَّل إعادة صــياغة ، أو تثــكيل

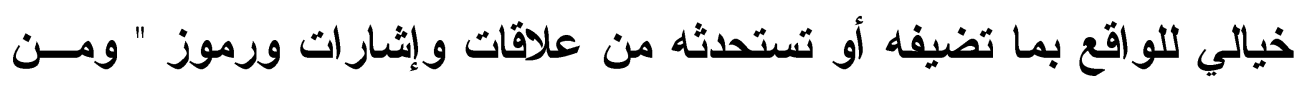

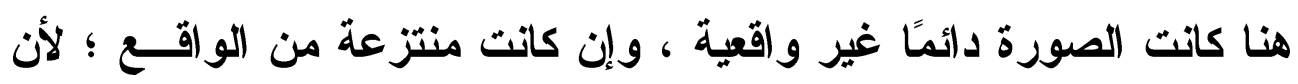

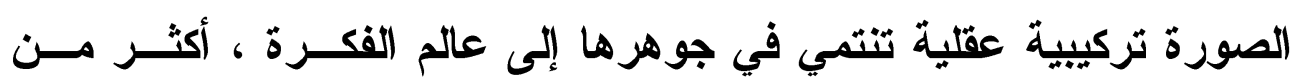
انتمائها إلى عالم الو اقع "(1) إنّ فنون دائرة التمثيل الأكية لا تبحث في الدالاة العقلية مسن حيــ

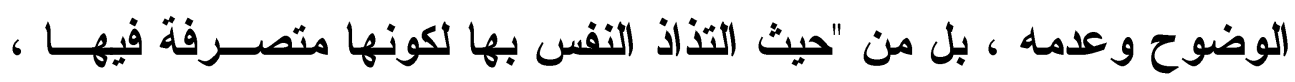

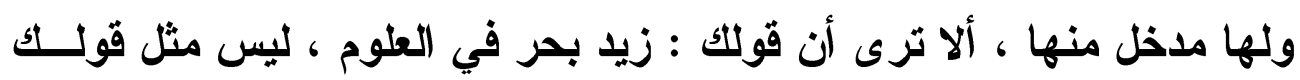

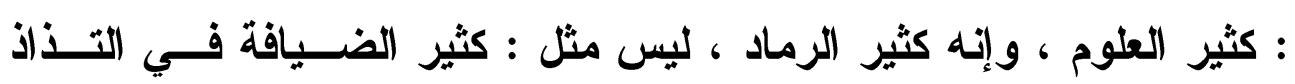

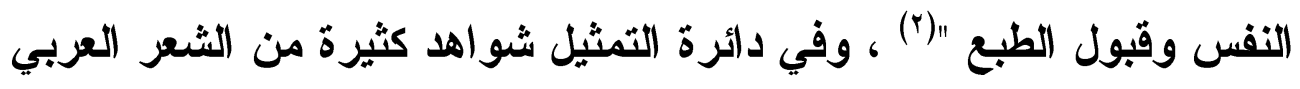

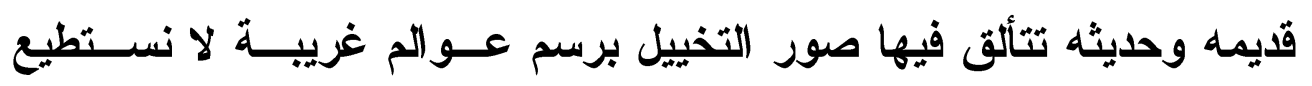

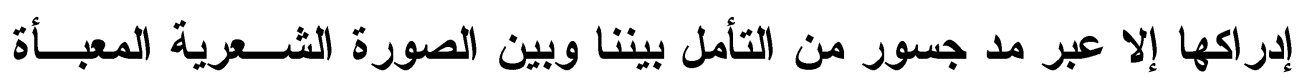

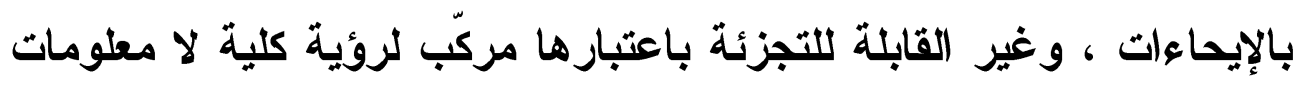

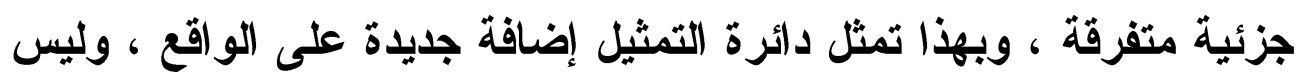

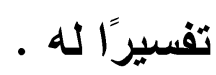

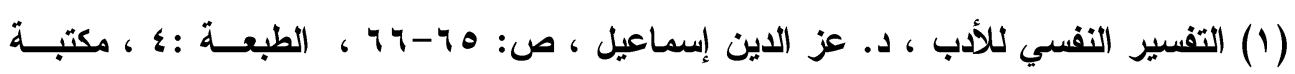

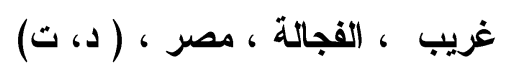

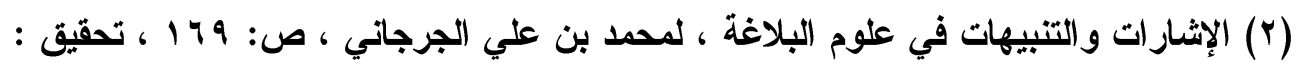

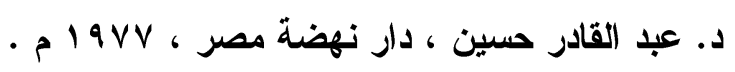


منى المعنى خارج دائرة التمثيل البلاغي

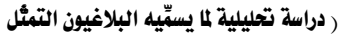

ومستتبعات التزاكيب )

أما دائرة التمثُّل فإنها تمثِّل دائرة أوسع من دائرة التمثيل على اختلاف

فنونها لو دققنا فيها النظر و التأمل .

نعم ، " التمثل بالثعر أوسع من المجــازات والكنايــات وهــو بــاب

الإثشارات التي قد تكون قريبة ، وقد تكون بعيدة ، ويقوم هذا الباب الجليـل

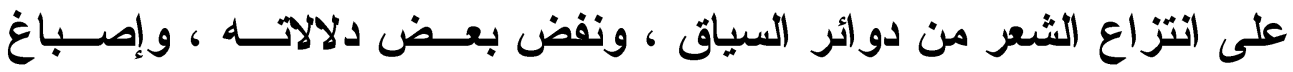

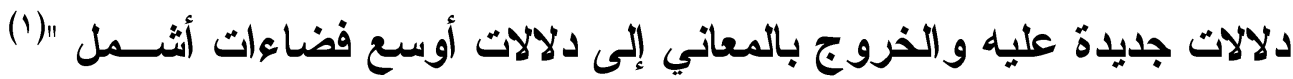

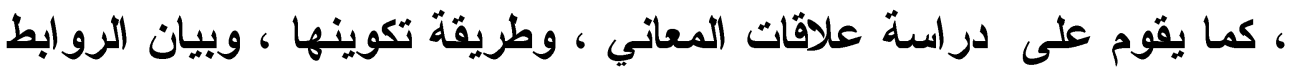

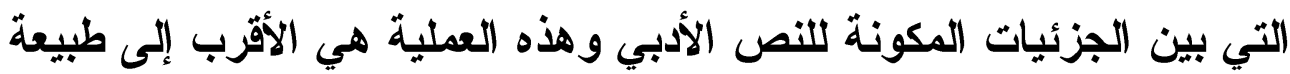

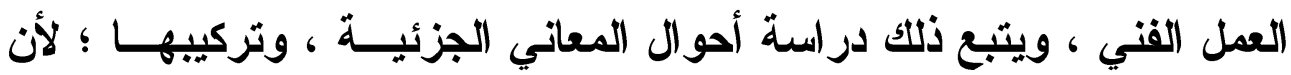
تلك العلاقات و الروابط والإثارات ، ودراسة مستتبعات التراكيب هي التـي

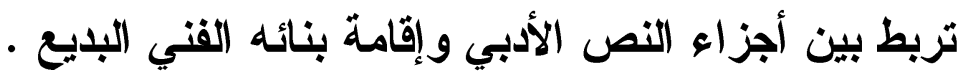
إن دائرة النمثُل وتنزيل الثعر على مضربه باب واسع في البلاغة لما للشعر من وقع في النفوس ، وسوقها إلى مكارم الأخلاق ، وتخليد المـآثر

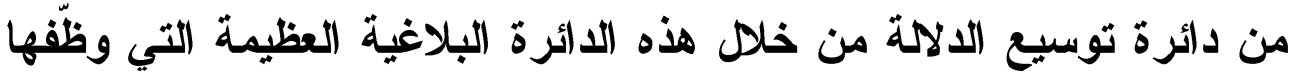

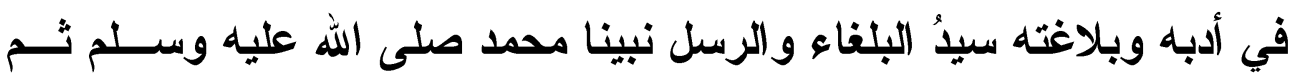
من جاء بعده من الخلفاء و العلماء والأدباء و الثعر اء الذين مارسوا بلاغــة

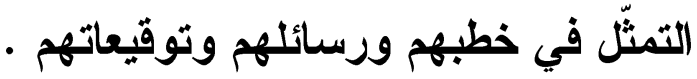

لكن التصوير عند العلماء والبلاغيين القدماء ليس تصــوير التثــبيه

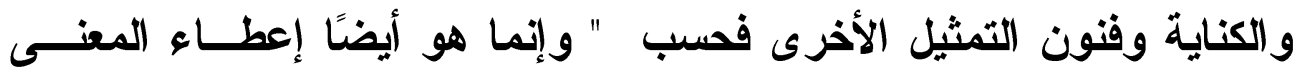

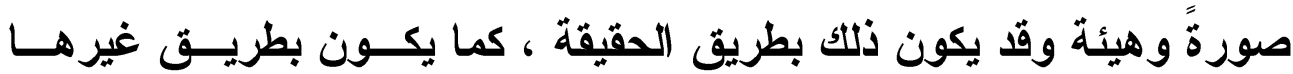

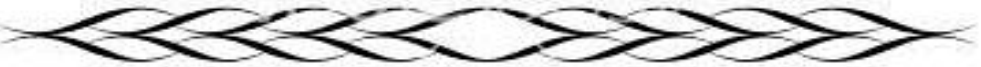




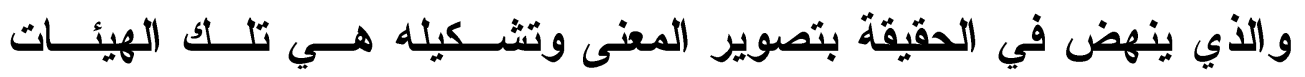

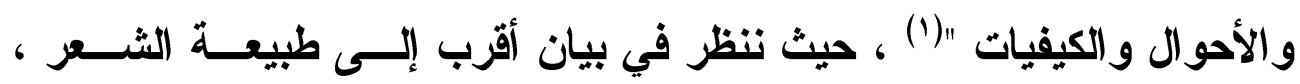

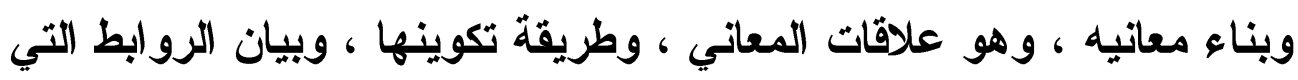

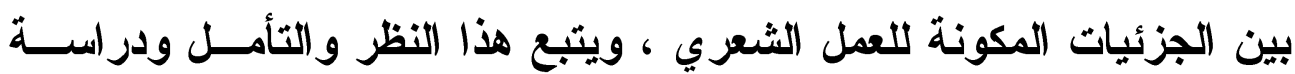

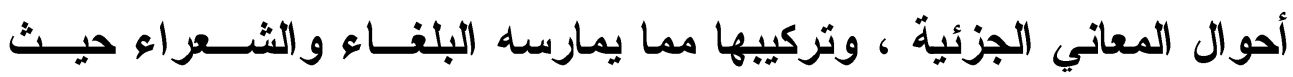

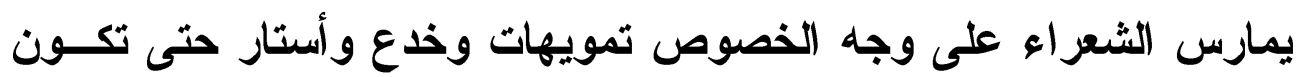

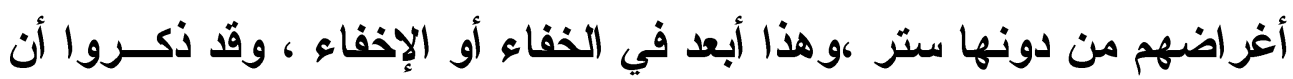

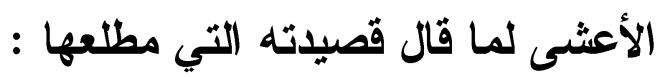

غضبى عليك فما تقول بـا لهــا

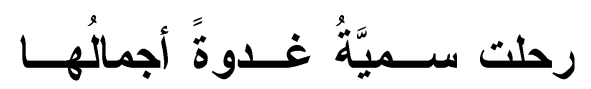
مـــالهــــا بالليـلـل زال زو الهــــا هذا النهارُ بدا لهــا مـن همّهــا

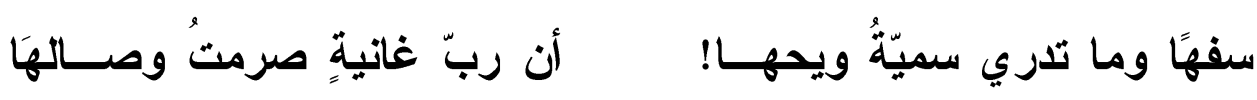

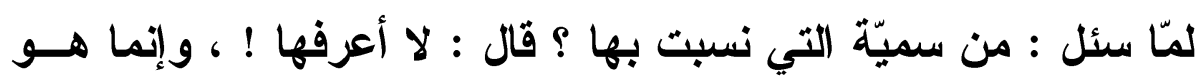

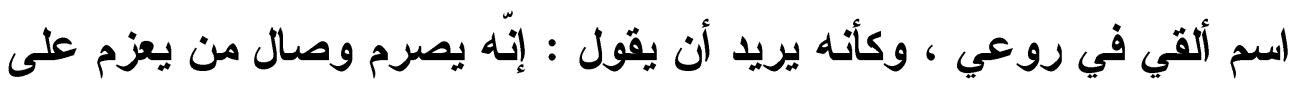

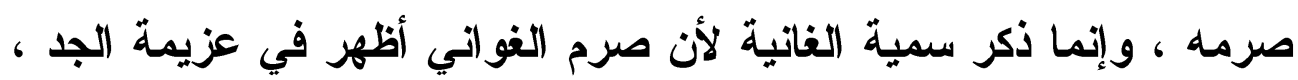

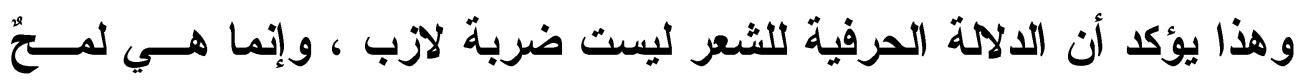

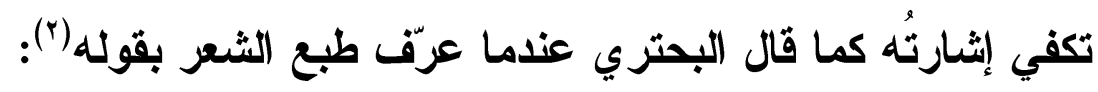

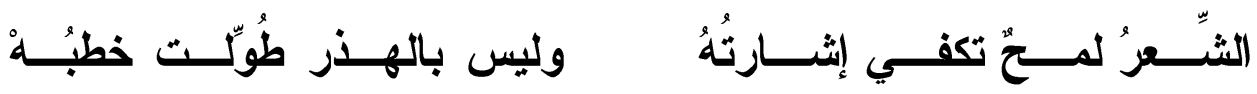

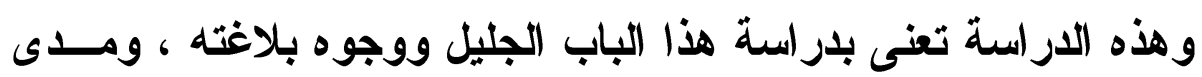

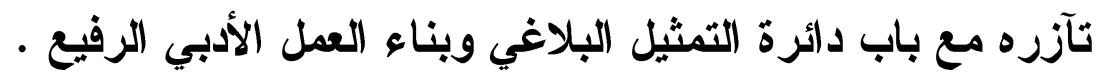

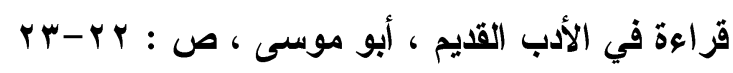

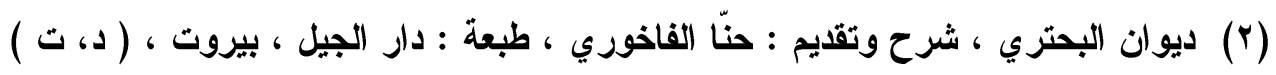


معنى المعنى خارج دائرة التمثيل البلاغي

( دراسة تحليلية لما يسمّيه البلاغيون التمثلئل

ومستتبعات التراكيب )
Q. 1 ir...

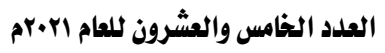

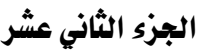

\section{البمث الثاني}

تصوير المعنى بين دائرتي التهثلُ الاغوي والتمثيل البلاغي

تحاول الدراسة في هذا المبحث الإجابة عن أسئلة من أهمهيا :

- لماذا رفض الثعر اء الوقوف بالثعر عند الدالة الحرفية ؟

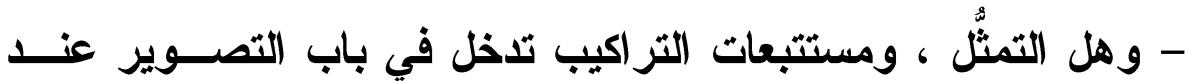

البلاغيين ؟ - إ

- و هل يمكن لائرتي التمثُّ ومستثبعات التراكيب ، و التمثيل البلاغي

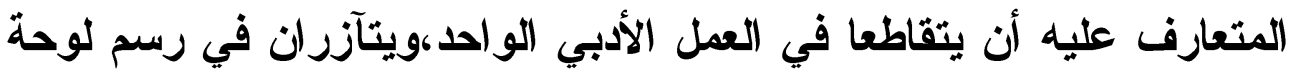

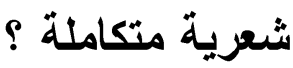

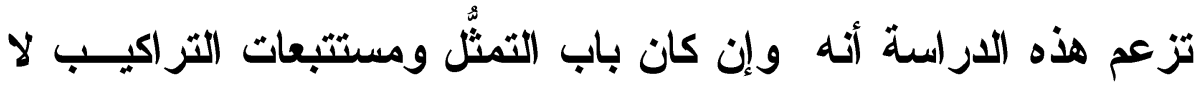

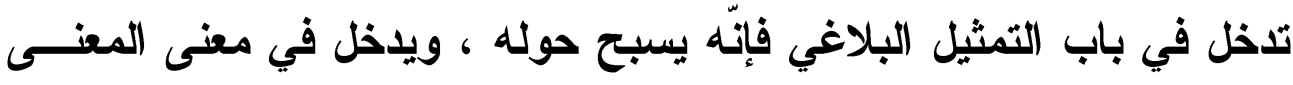

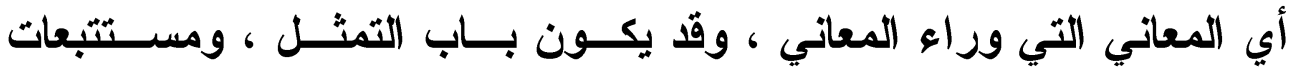

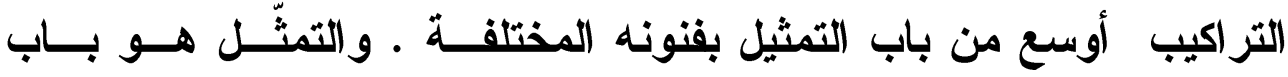

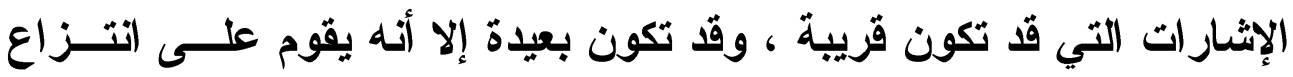

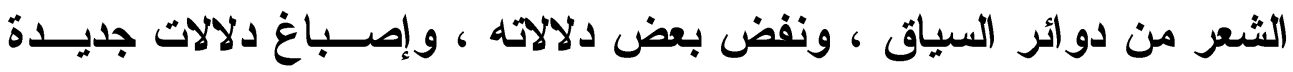

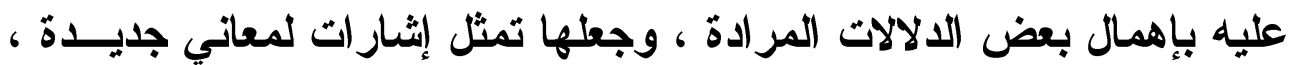

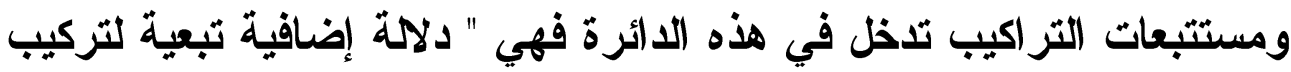

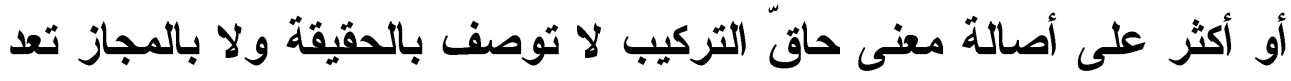

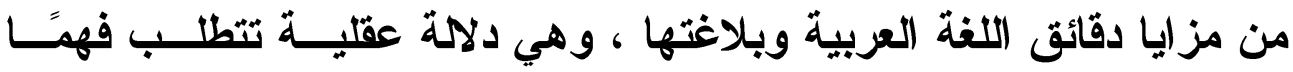

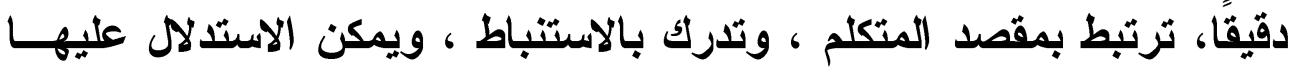
من القرائن ومن نظم الكلام "( (")

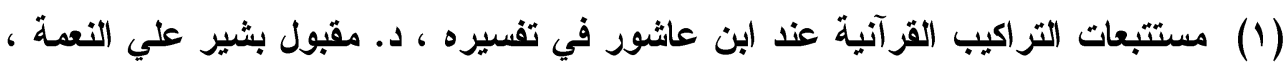

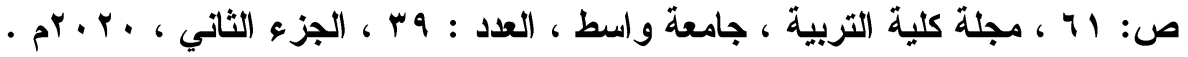

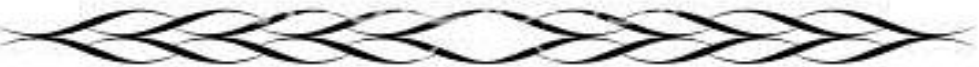


إن الثعراء يرفضون الوقوف بالثعر عند الدلالة الحرفية ، فكم مسن

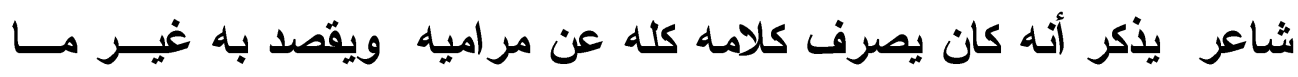

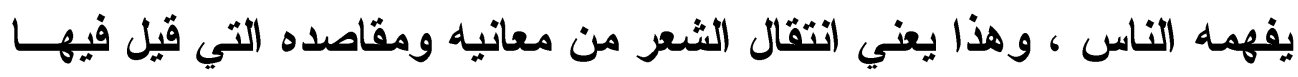

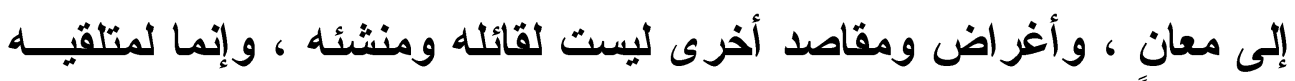

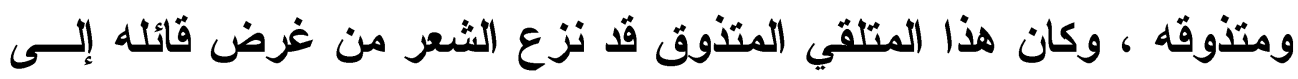

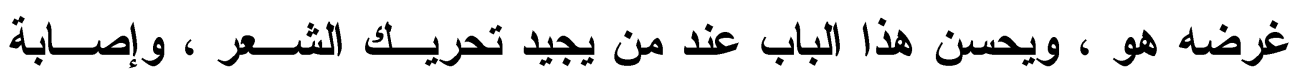

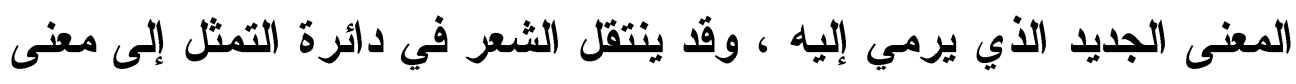

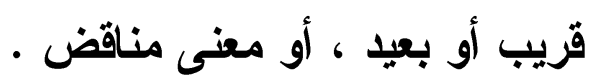

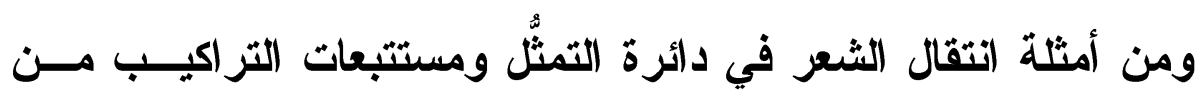
المعنى الأصلي إلى معاني ودلالات جديدة أن الخليفة المأمون أراد يومَّــا

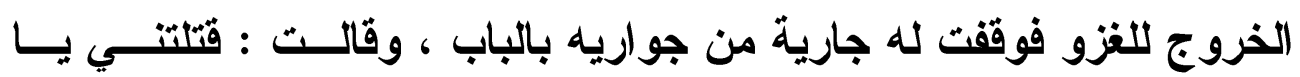

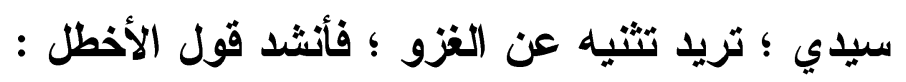
قومُ إذا حاربوا شـــوا مــآزرهم دون النساء ولو باتــت بأطهــار ثم تولّى عن الجارية وسار إلى الغزو. (1) ومن أمثلة التمثل بالثعر أيضًا تمثل الثعبي عندما مر بقوم يثتمونه

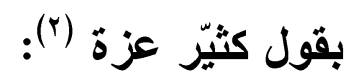

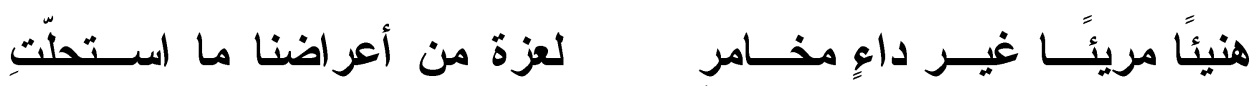

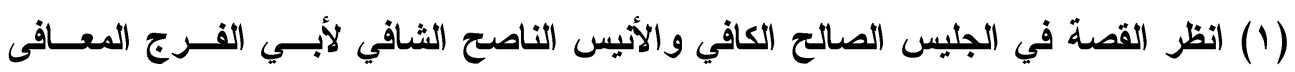

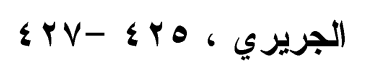

(r) أبيات الاستثهاد لابن فارس ، محمد إبراهيم الحمد ، ص : 9 ، ، مكتبة الملك فها الوطنية

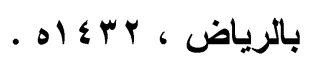


منى المعنى خارج دائرة التمثيل البلاغي ( دراسة تحليلية لما يسقيّيه البلاغيون التمثئل

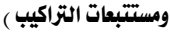

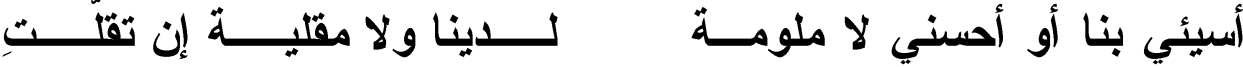

وترى الدراسة أن التمثّل في العمل الأدبي يأتي على أوجه كثيــرة ، وليس فقط وجه الاستثهاد والتمثل بالثثعر وإنما علينا أن نستفيد من المعنى

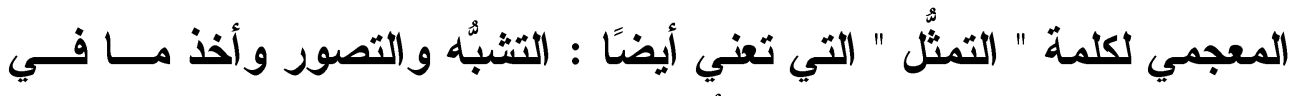

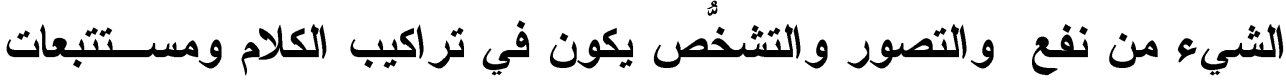
التر اكيب حيث يحاول الإسان أن يصور أحاسيسه وأفكاره ومشاعره بالتعبير

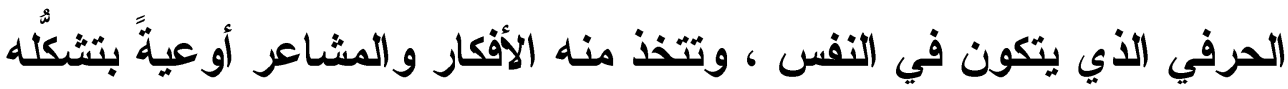
بحسب ترتيب المعاني في النفس لأن السياق النظمي للكلام هو تصوير لله ،

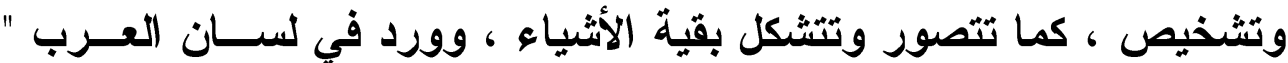

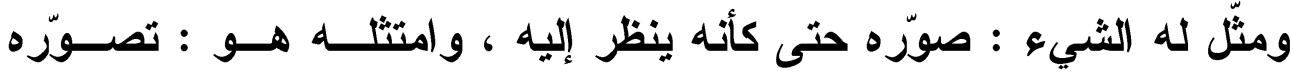

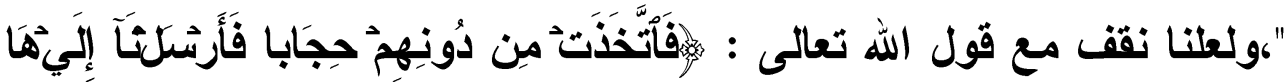

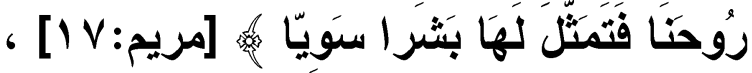

إنّ تصوُّر الملك في صورة إنسان سويٍٍ لمريم عليها الســلام ، إنمـــا جعله الله كذلك حتى لا تخاف منه ، ويكون من جنسها البشري المــألوف ،

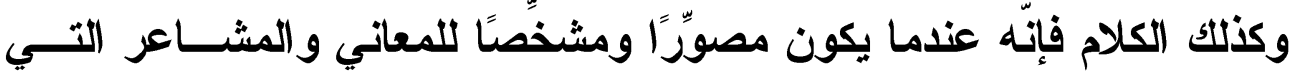

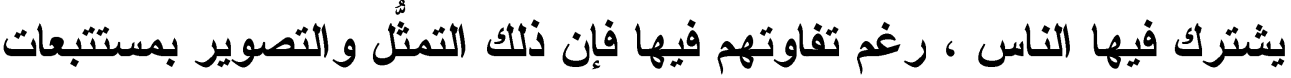

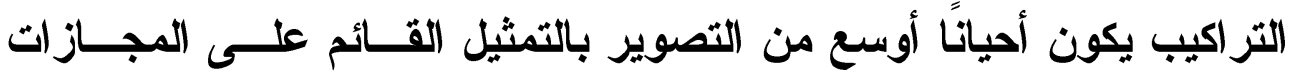

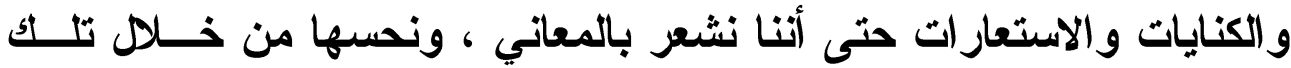
التراكيب السياقية ، " و الأي ينهض في الحقيقة بتصوير المعنى وتثكيله هي تلكك الهيئات و الأحوال و الكيفيات ... فصورة المعنى فــي قـول الخنســـاء : " الواهب المئة الهجان " ليس كصورته في قولنا : يهب المئة الهجسـان لأن صيغة الفعل تعطي صورة المعنى وكأنه يحدث في مرأى العين ، أما التعريف

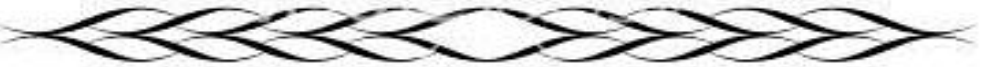


فإنه يعطي معنى آخر و أن هذا الفعل خاص به ، وهذا شيء له طبع ومذاق

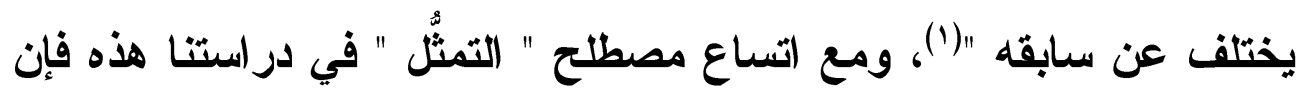

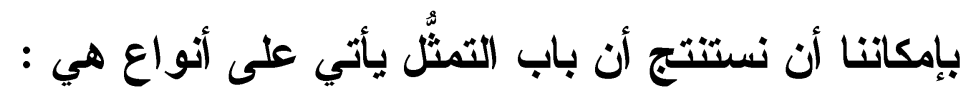

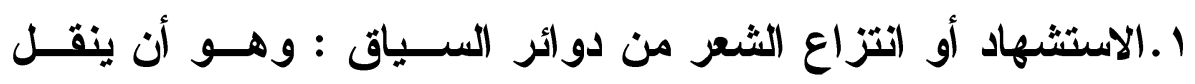

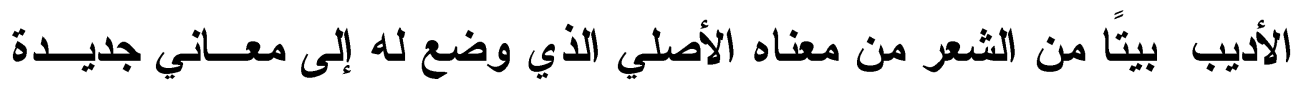

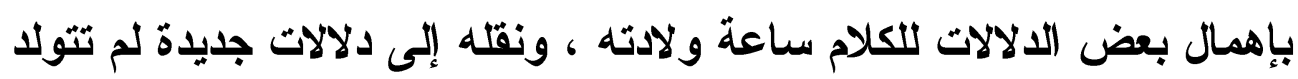

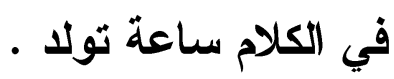
ومن الأمثلة على ذلك ما فعله الحسن البصري في قول الثشاعر : اليوم

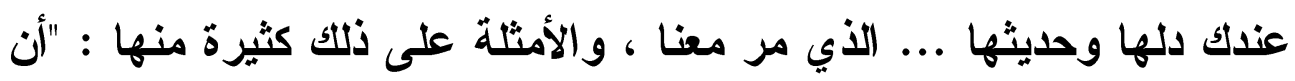

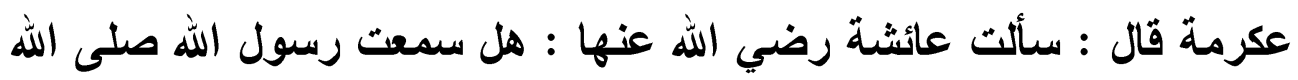

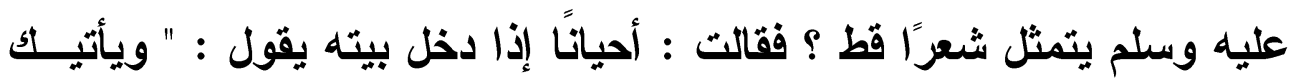

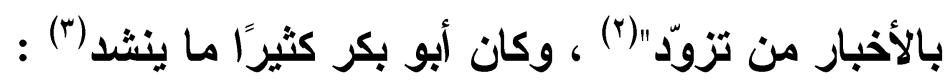

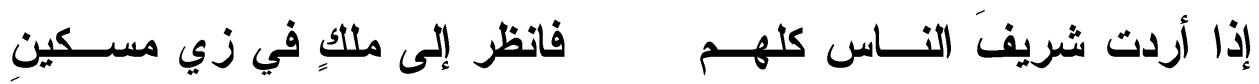

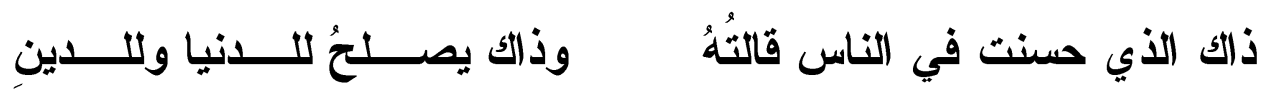
وكان عمر بن الخطاب رضي الله عنه لا يكاد يعرض له أمر إلا أنثــــ

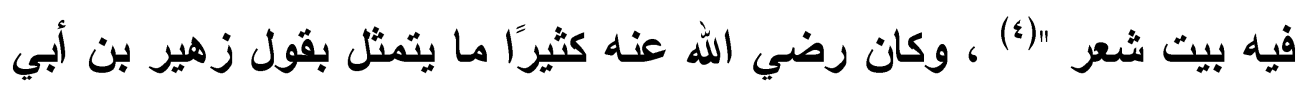
سلمى : بل

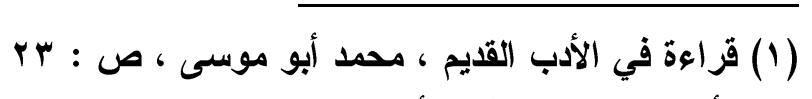

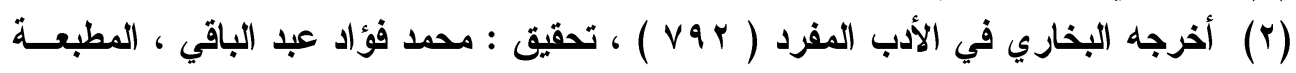
السلفية ، كV

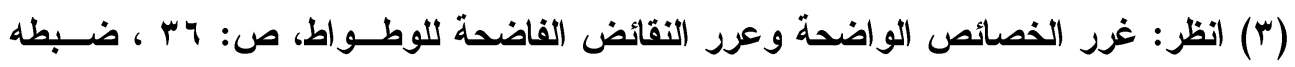

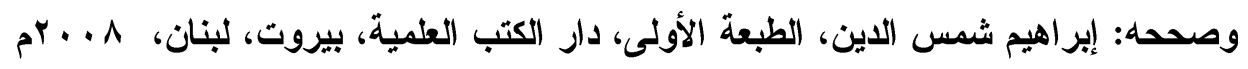

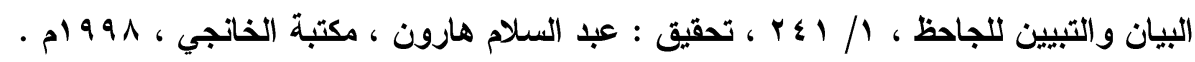


معنى المعنى خارج دائرة التمثيل البلاغي

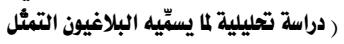
ومستتبعات التراكيب )

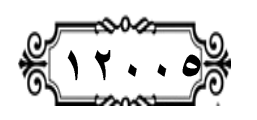

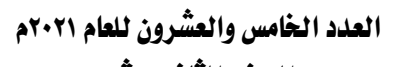
الجزء الثاني عشر المشرو

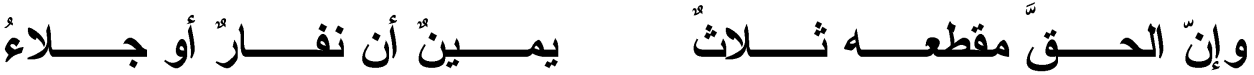
r.الاكتفاء بحديث الثعر دون حدثه : أي : رفض الوقــوف بالثــعر

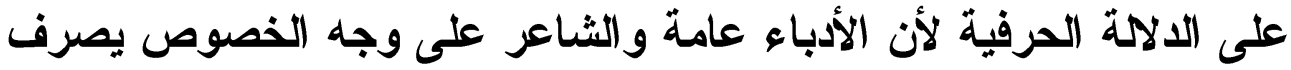

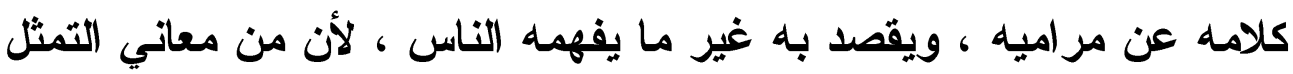

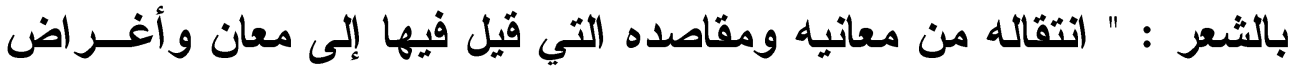

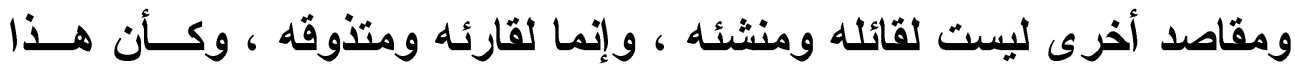

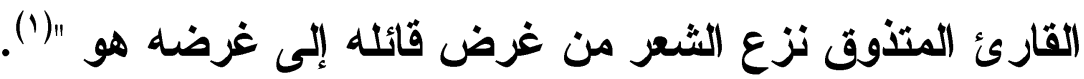
والأمثلة لذلك كثيرة منها أن أديبًا قـ ينقل قول الثـــاعر قـيس بـن

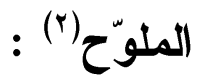

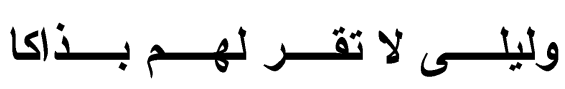

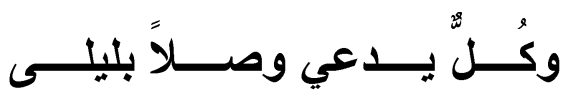

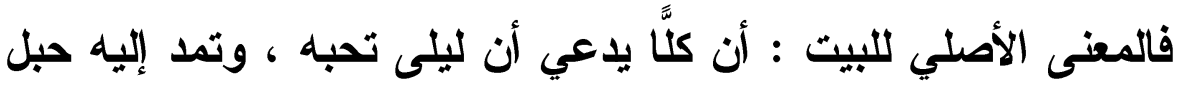

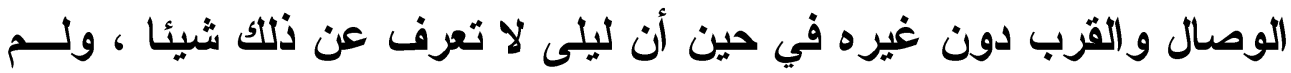

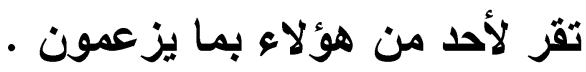

ويضرب هذا البيت مثلا لمن يدعي شيئا من غير دليل ، وكلمة شــيء

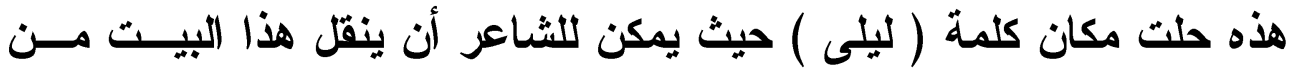

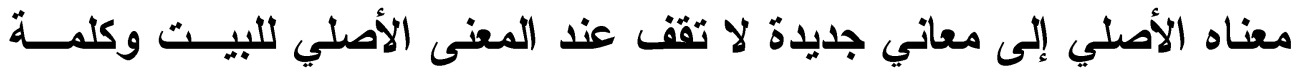
ليلى على الأخص ، ويمكنتا ذكر هذا البيت في معنى جديد ومناقض لمعنــاه

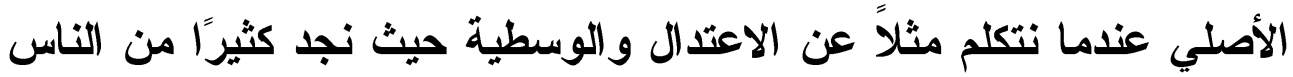

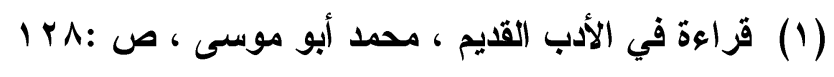

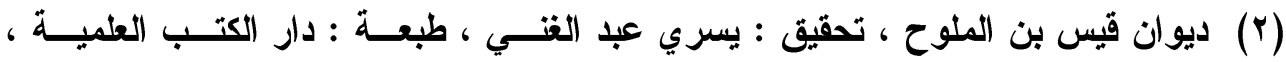




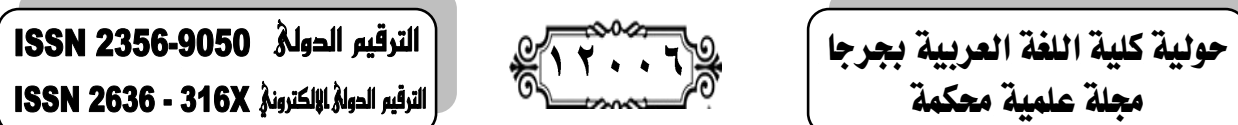

يدعي الوصل بها ، وأنه من أهلها ، وأنها نهجـهـ وحياتــه التــي يحياهــا

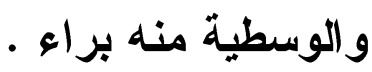

وفي قصيدة البردة لكب بن زهير رضي الله عنه نزى كيــف نقــل

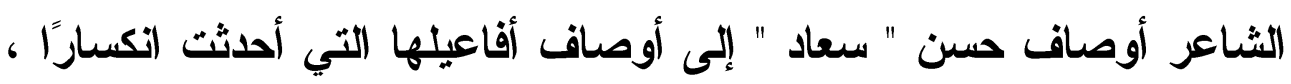

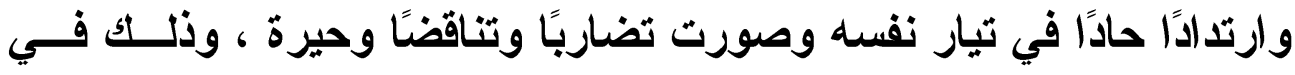
قوله : - و

أكرم بها خلة لو أنهــا صـــت موعودها أو لو أن النصح مقبول تأمل التعجب في قوله " أكرم بها ... ! " ثم تحسس النــدم والضــياع و الفقد في قوله : " لو أنها صدقت " في هذا الأسلوب يظهر مغنى التمني في

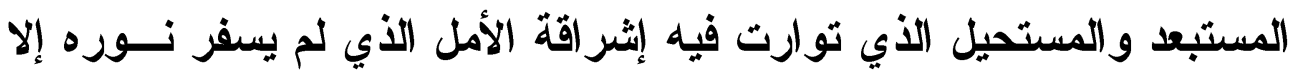
بعد عدة أبيات من القصيدة . r. التمثُل بمستتبعات التزاكيب وأثر بناء الجمل في بنــاء المعـاني : ومعنى ذلك أن التصوير للمعاني قد يحدث من ولآد التصرف الأكي والواعي

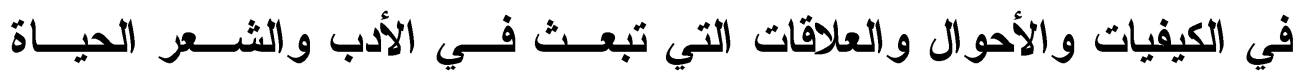

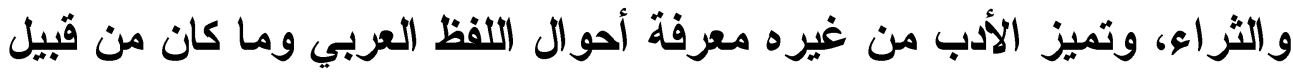

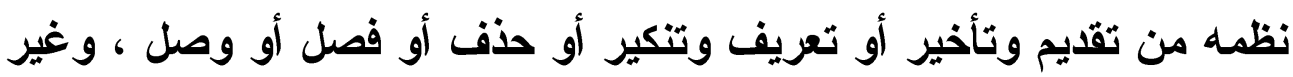

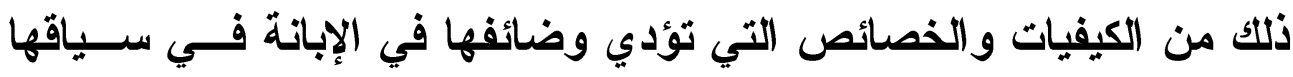
• الفسيح

إن المنهج التحليلي المهتدي بأحوال اللسان وطرائق الأداء يفتح لنــا ناقذة خفية ندرك منها مغازي الكلام الأي يرمي إليه المبدعون . 
وجدّة اللغة لا تعني استخدام كلمات جليدة بل تعني اكتساب الدلالة من خلال العلاقة داخل السياق ، ومن هنا ندرك عناية عبد القــاهر الجرجـاني بثرح دلالات الألفاظ واختلافها باختلاف مواقعها في تر اكيب الكلام "فتستخدم اللغة على مستوى فني جمالي بصــياغتها علــى ألــوان مــن التثـــيهات والاستعارات والصور الفنية ، حيث تتخذ الألفاظ والتراكيب أوضـــاعًا فنــــة

جمالية تعتمد فيها على الإيحاء غير المحدود"(')

ففي قول المتنبي) () :

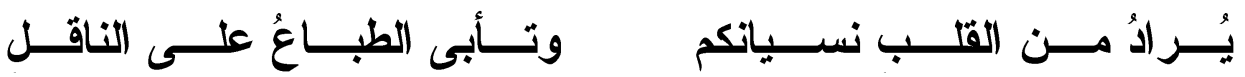

إن المعنى في بيت المتنبي له هيئة وصورة حين جعل الإباء فعـلاً

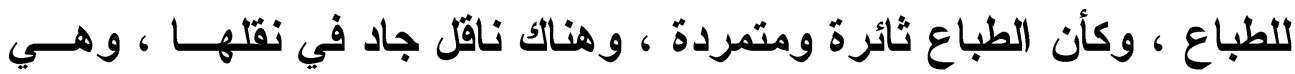
أيضًا جادة في الرفض والإباء بعناد وصلابة ، بينما نفقد هذه الصورة الحية

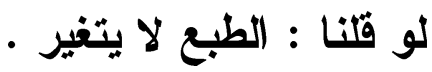

ـ. تلوين الخطاب : وهو ما يسميه بــض البلاغيـين ( الالتفــات )

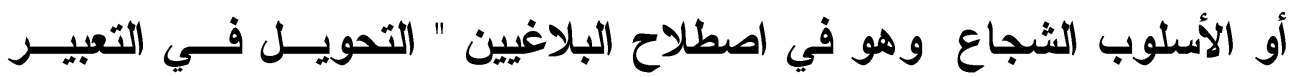

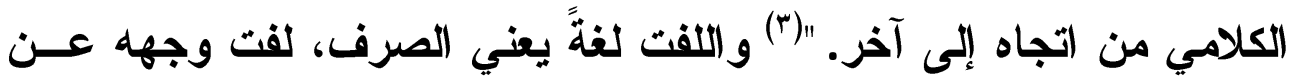

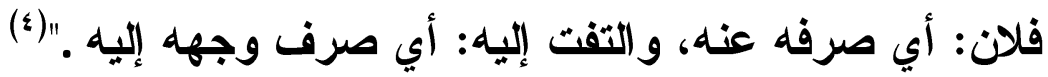

( (1) العربية والغوض ، ص: · ץ ، حلمي خليل ، دار المعرفة ، الإسكندرية ، الطبعة الأولى ، - 1911

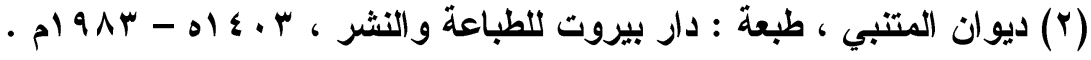

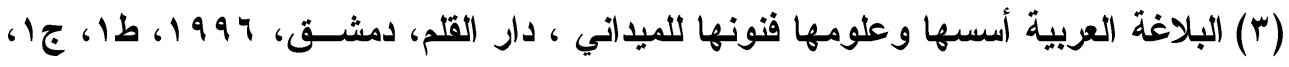
ص: لسان العرب لابن منظور ، دار الكتب العلميّة، بيروت، طا، مادة (ل، ف، ت) .

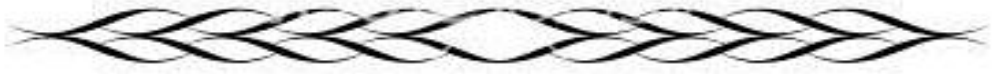




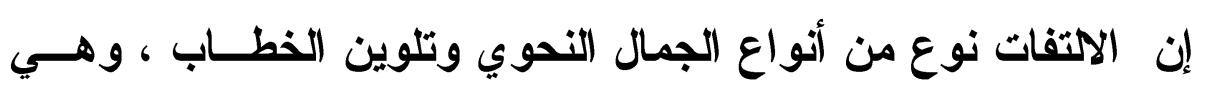

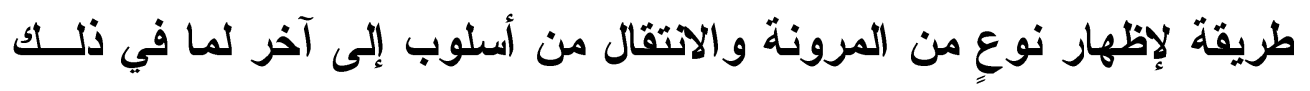

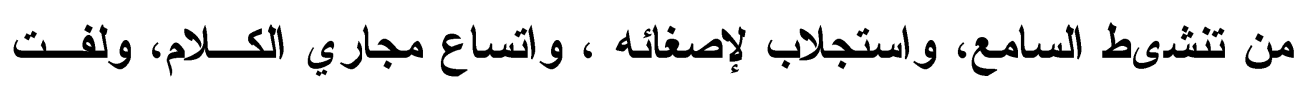

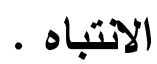

\section{وللنظر إلى تلوين الخطاب في قول كعب بن زهير(') :}

\section{والعفو عند رســول الله مــأمول}

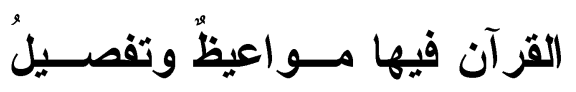

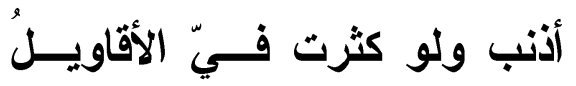

\section{نبيّــــتُ أن رســول الله أوعـدني} مهلاً هدالك الذي أعطاك نافلة الـ ألـ

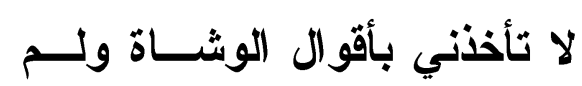

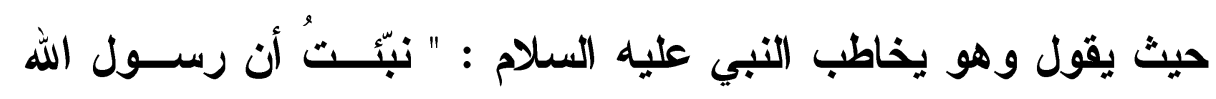

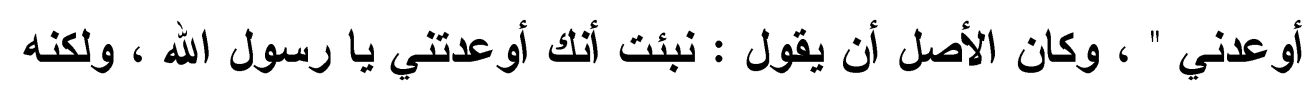

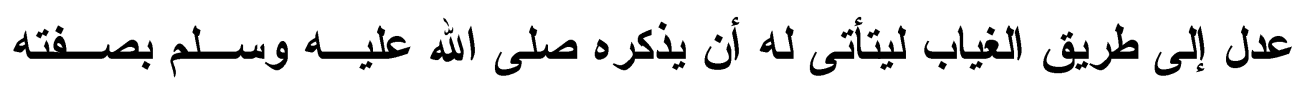

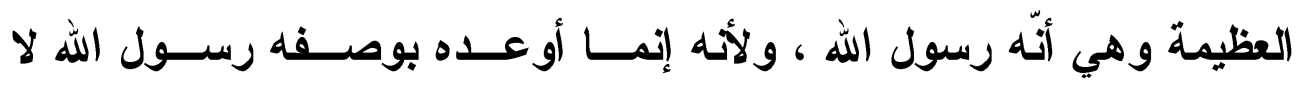

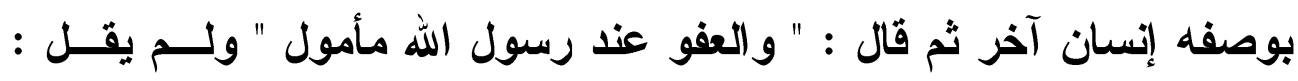

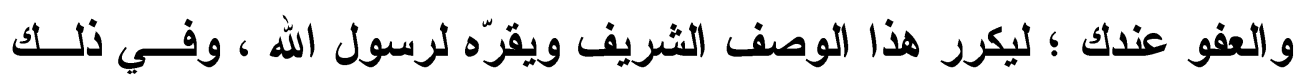

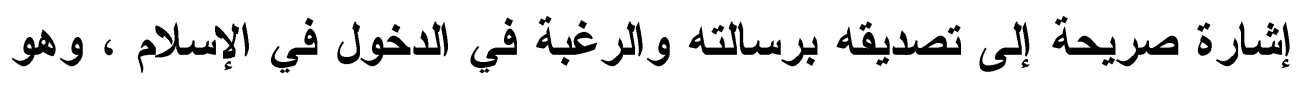

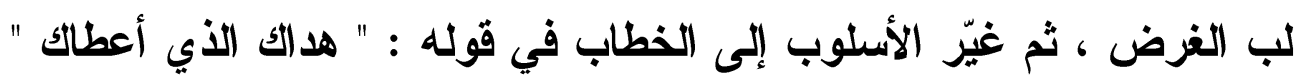

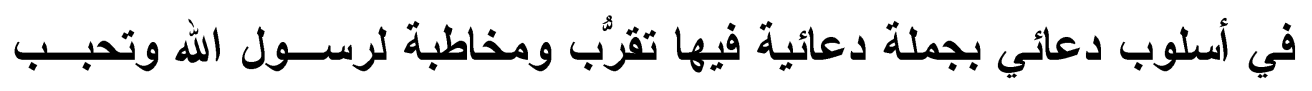

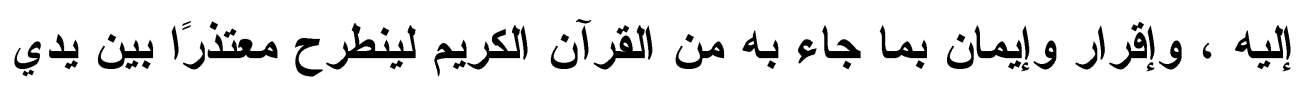

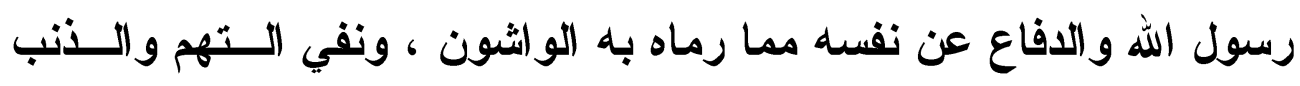

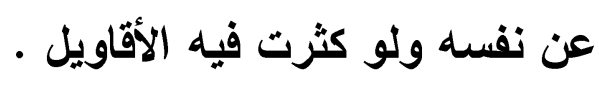

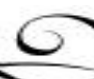


مغنى المعنى خارج دائرة التمثيل البلاغي ( دراسة تحليلية لما يسقيّيه البلاغيوز التمثئل ومستتبعات التراكيب )

لقد استطاع الثاعر أن يصور لنا حاله أمام رسول الله صلى الله عليه

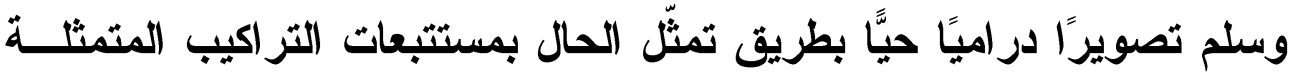
في تلوين الخطاب خارج دائرة التمثيل الأكية المتمثلة في المجاز وفنونه . و هذا يؤكد أن الثـاعر يمتاز بلغة خاصة تنظر إلى أثـــيائه بثــفافية

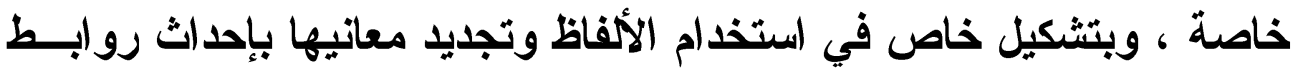

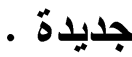

إن كل ما تقدم من تصوير فني بمستتبعات التراكيب هو ما تسعى هذه

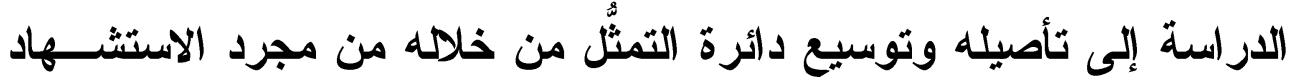
بالثعر وغيره إلى دائرة التصوير للمعاني من خلال جدّة اللفة التي لا تعني

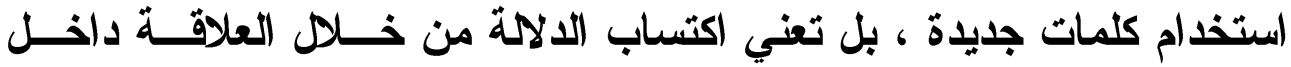

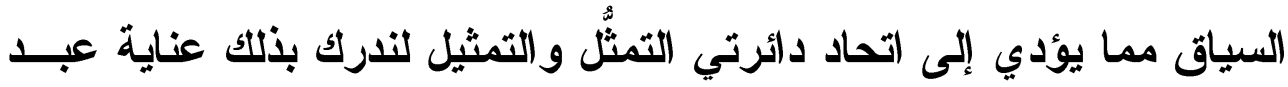

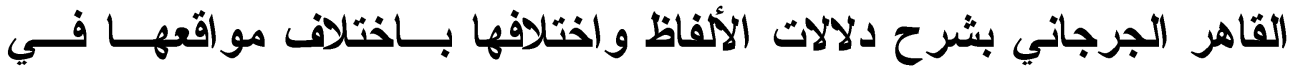

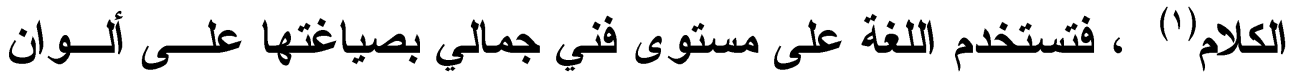
من التشبيهات والاستعارات والصور الفنية ، حيث تتخذ الألفاظ والتراكيـب

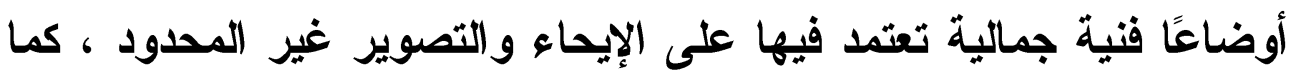

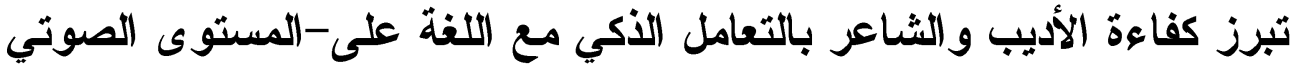
(الموسيقي) والصرفي و النحوي - في تثكيل موقفه لأن للأدب الرفيع لغته لهنه

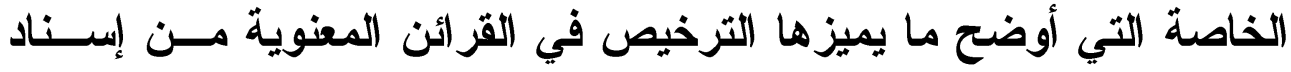

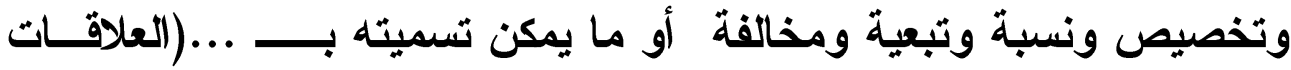

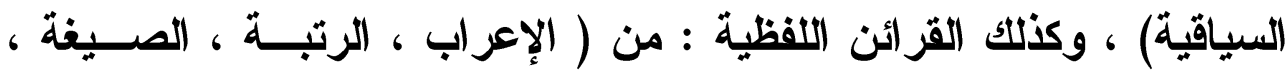
(1) دلاثل الإعجاز ، عبد القاهر الجرجاني ، تعليق محمود محمد شاكر ، ص :0 ؛ ؛ ، مطبعة دار

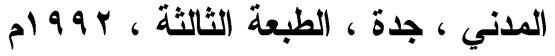

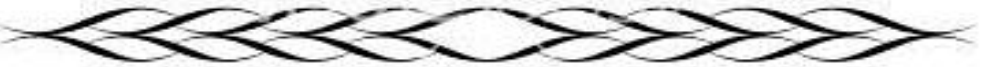


المطابقة ، الربط ، التضام الأداة ، التنغيم ) حين يكون المعنى هــو الـــي

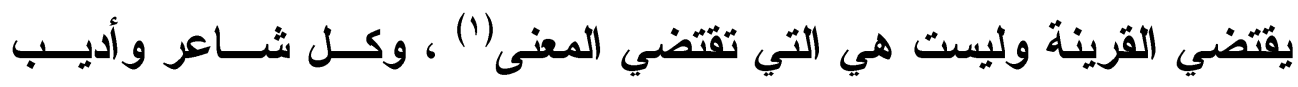

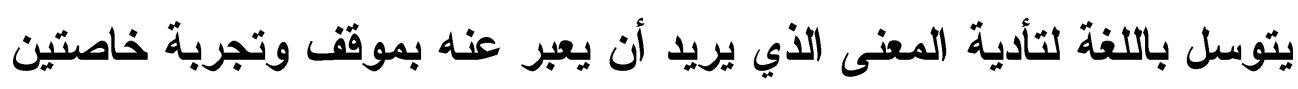

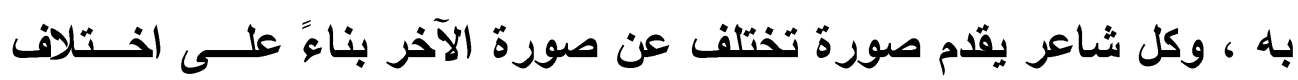
ألوان ألفاظه ، وطريقة صياغتها .

وتكتسب اللغة شعريتها " حين تقيم ترتيب علاثات جديدة بين الإنسان

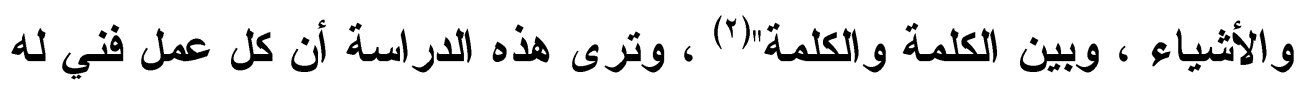

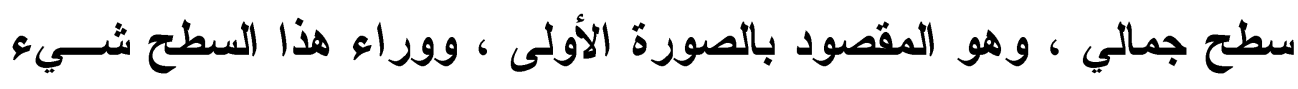

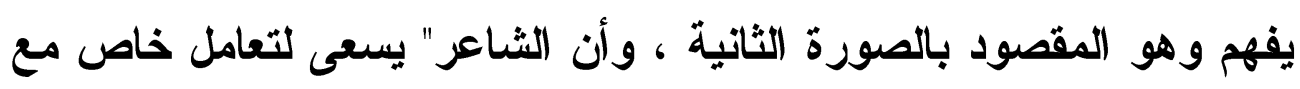

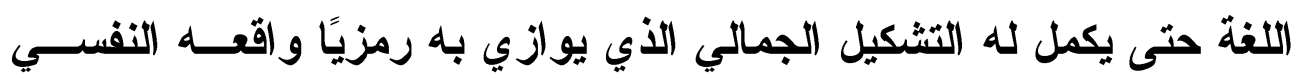

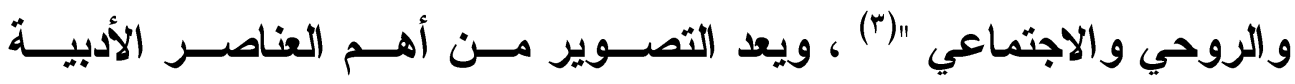

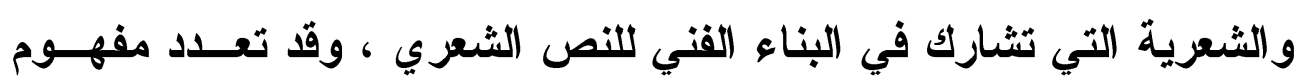

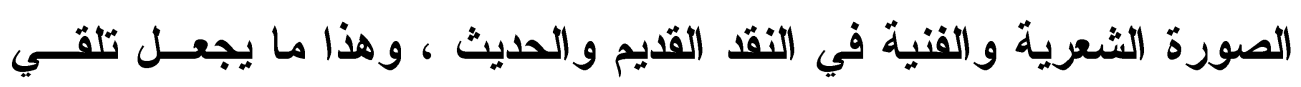

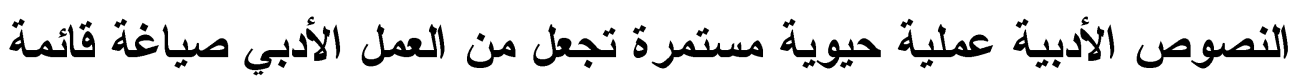

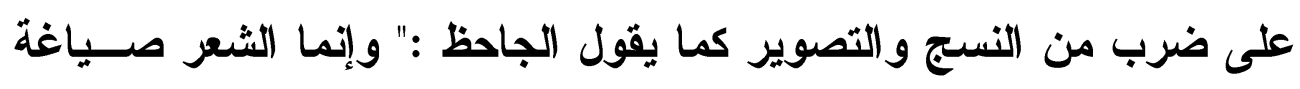

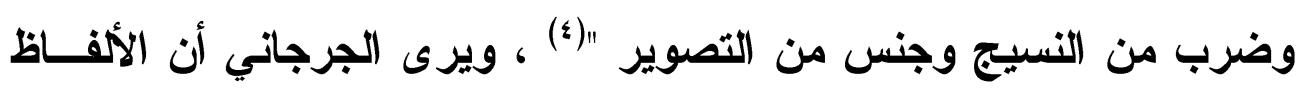

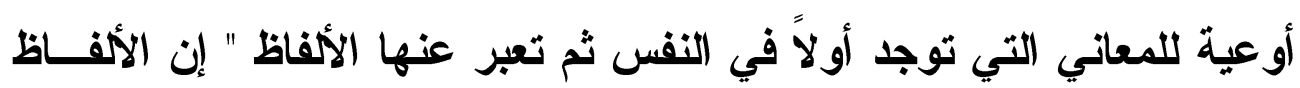

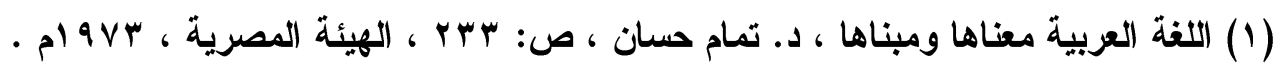

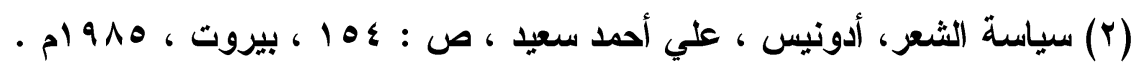

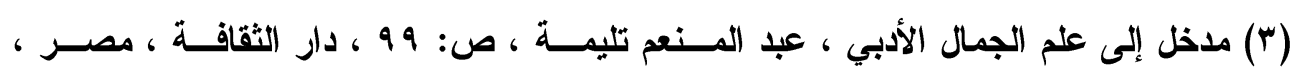
- $19 \vee \wedge$

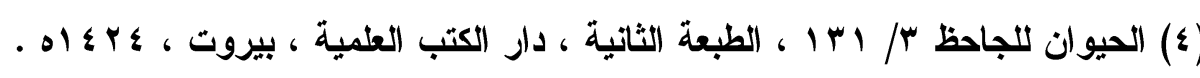


معنى المعنى خارج دائرة التمثيل البلاغي

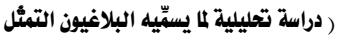

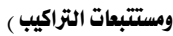

إذا كانت أوعية للمعاني فإنها لا محالة تتبع المعاني في مواقعها فإذا وجـبـ المعنى أن يكون أولاً في النفس وجب للفظ الدال عليه أن يكون مثله أولاً في

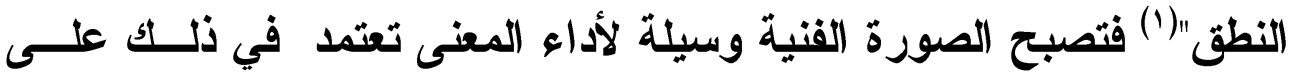
تنسيق الألفاظ وترتيبها في النص . ه. التعريض : وهو من مستتبعات التزاكيب البلاغية و هو " ما أثثير

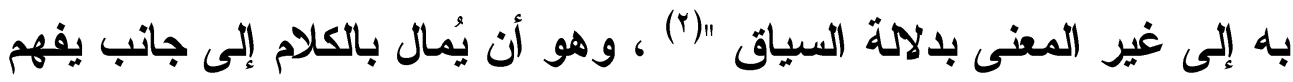

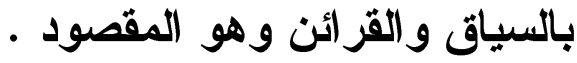

و التعريض ليس من مفهوم الحقيقة فقط ، ولا من المجــاز ، ولا مسن

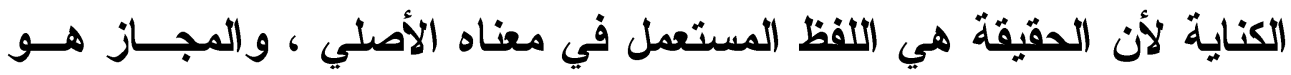
المستعمل في لازم معناه فقط ، والكناية هي المستعمل في اللازم مع جــواز لاز إرادة الأصل ، و التعريض أن يفهم من اللفظ معنى بالسياق والقرائن من غير في لفي أن يقصد استعمال اللفظ فيه أصلاً ، وبهذا يكون التعريض هو ما أثثير بــه إلى أمر آخر غير ما أُستعمل فيه اللفظ من حقيقة ومجاز وكناية . ويقع التعريض في الجمل المترادفة ، والألفاظ المركبة ، وتكون دلالته حاصلة من جهة القرينة والتلويح والإشارة . ومن أمثلة التعريض ما روى (بن عباس رضي الله عنهما: " لما نزلت إذا جاء نصر الله والفتح، نعيت إلى رسول الله صلى الله عليه وسلم نفسـهـ،

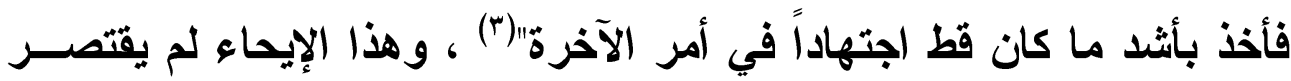

$$
\begin{aligned}
& \text { (1) دلآل الإعجاز للجرجاني ، ص: ro هو ه }
\end{aligned}
$$

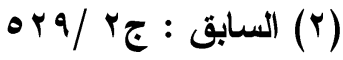

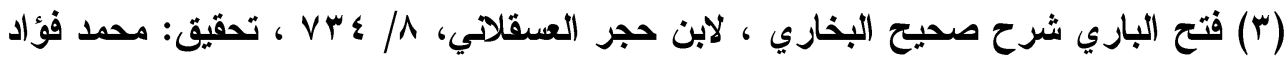

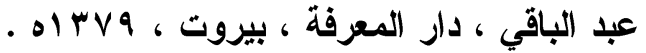


فهمه على النبي صلى الله عليه وسلم، بل فهمه كذلك عمر وعبـــ الله بـن

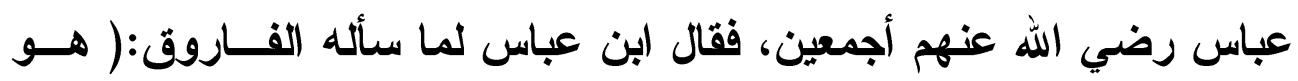

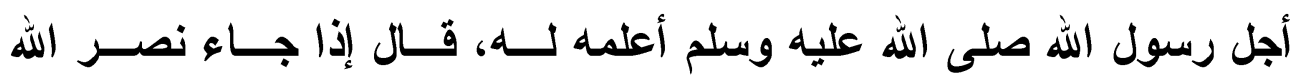
و الفتح- وذلك علامة أجلك- فسبح بحمد ربك واستغفره إنه كان توابا. قال عمر: ما أعلم منها إلا ما تعلم).

وكقوله صلى الله عليه وسلم عن (بن عمر رضي الله عنهــا: "تعـــ

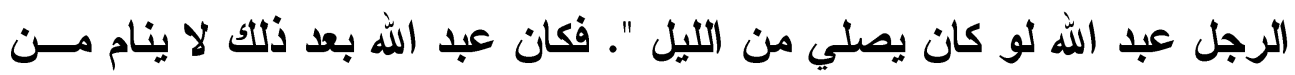

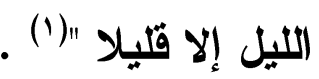

وقد يقول الثابّ الراغب في الزواج لوالديه: (بنة عمّي صارت ناضجة

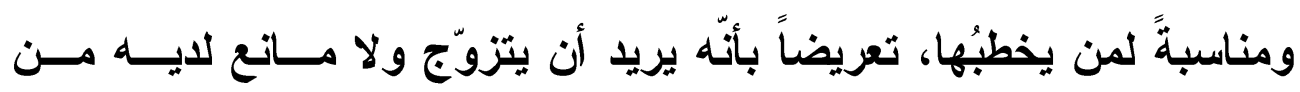
خطبتها له .

والتعريض لا يفهم المعنى فيه من جهة الحقيقة ولا من جهة المجاز،

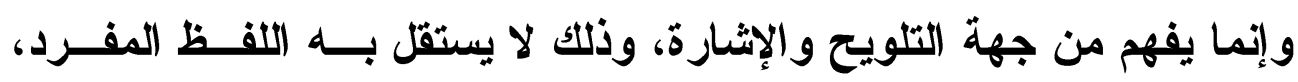

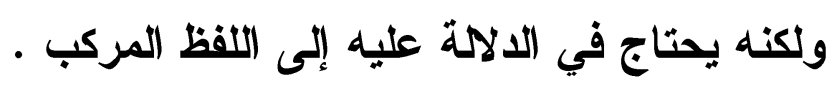

وققت امر أة على قيس بن عبادة فقالت: أثنكو إليك قلة الفأر في بيتي.

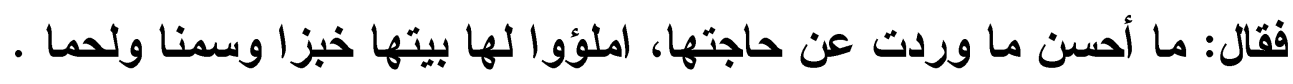
وكتب عمرو بن مسعدة الكاتب إلى المأمون في أمر بعـض أصــابه

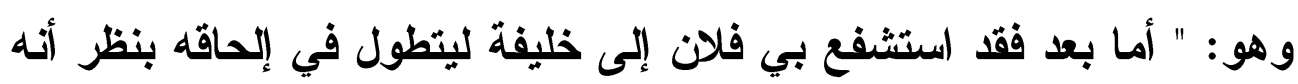

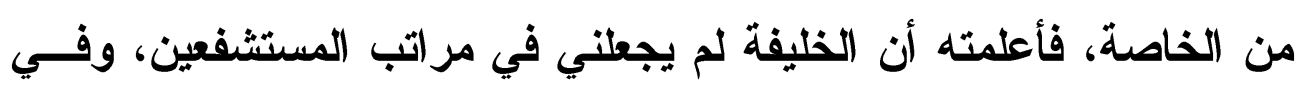
(1) صحيح مسلم كتاب فضائل الصحابة باب من فضائل عبد الله بن عمر رضي الله عنهما \&/

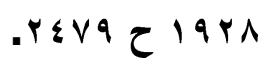


معنى المغنى خارج دائرة التثثيل البلاغي

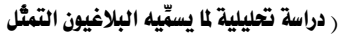
ومستتبعات التراكيب )

ابتدائه بذلك تعدى طاعته ". فوقع المأمون في ظهـر كتابــه قــــ عرفــــ

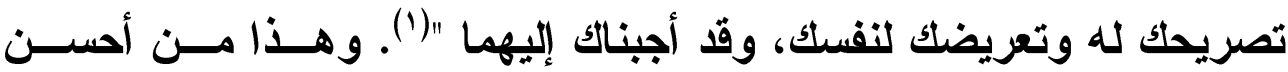

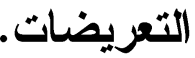

وفي التعريض مزيد إخفاء يجطُهُ أكثر قولاً حينما يكون التصريح مثيراً

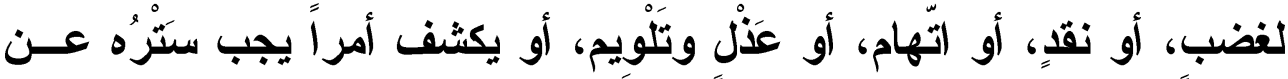

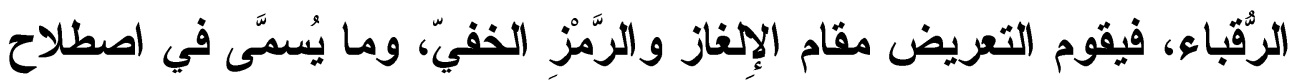

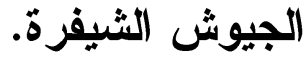

ويمكن أن يتحقق معنى المعنــي والتصــوير بـين دائرتـــي التمثُّـل

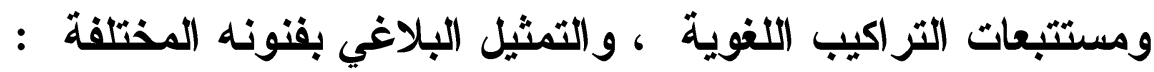
مثلما تقوم الصورة على شيء مما يشبه التثبيه والاستعارة ، فهـي

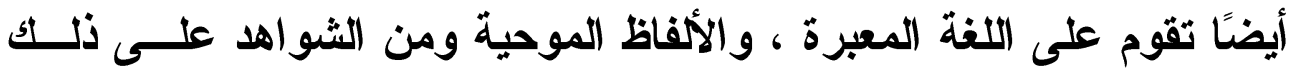

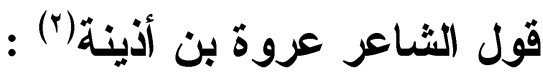

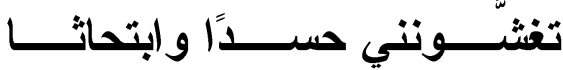

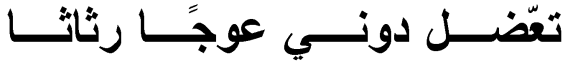

وينتجثــــون القبــيحَ انتجائُســا

وهم يعرضــون لحومَّا غثاثــا

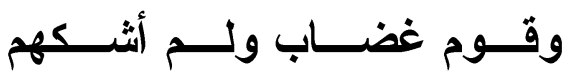

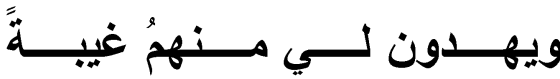

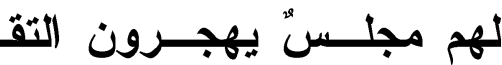

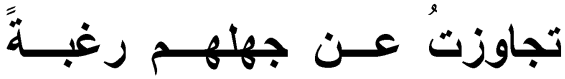

هذه صورة مركبة لأكاس يحسدونه ويغتابونه ، ولهم مجلس يهجرون

فيه التقى ، ويستعرضون فيه القبيح المهزول من القول ، وهو مع ذلـــــ لا يقابل الإساءة بالإساءة بل يكتفي بالإيحاء لهم حين يقبح سلوكياتهم السلبية

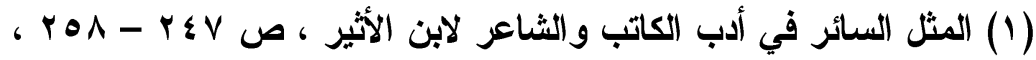

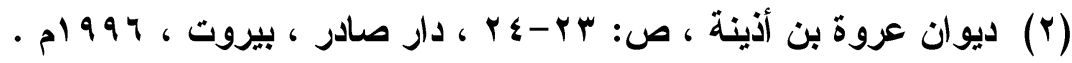


لتنفر منها النفوس ، ويحسن السلوكيات الإيجابيــة المتمثلــة فـــي تجنبــهـ

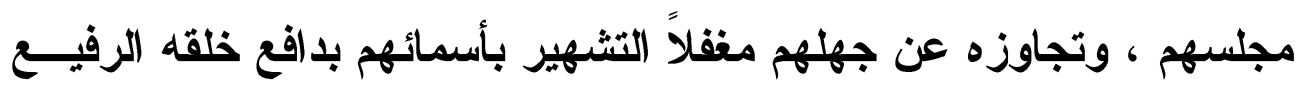

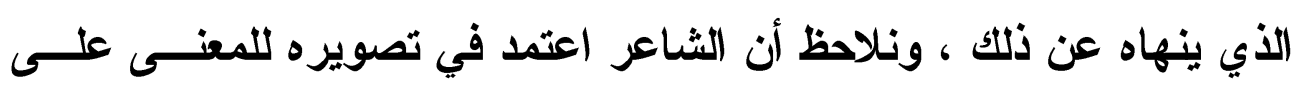

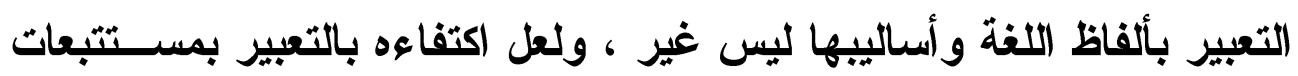

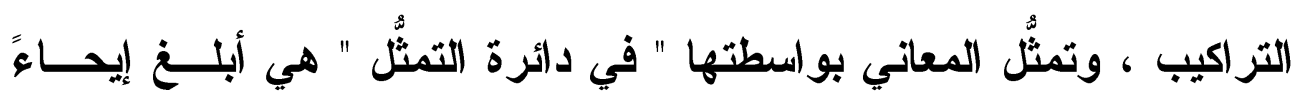
وأثثد تصويرًا من المجازات والكنايات والاستعارات في دائرة " التمثيل " . إن الثعور يظل مبهمًا في نفس الثـاعر فلا يتضح إلا بعد أن يتشــكل

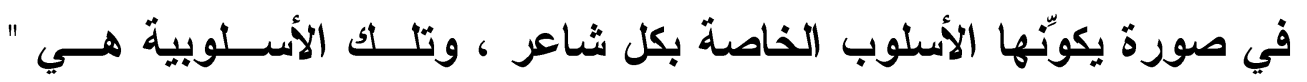

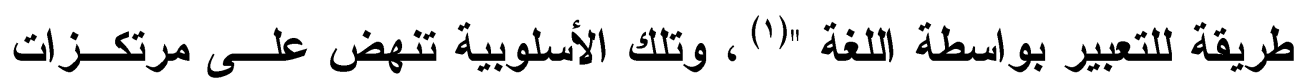

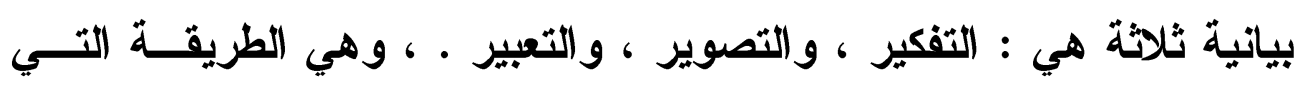

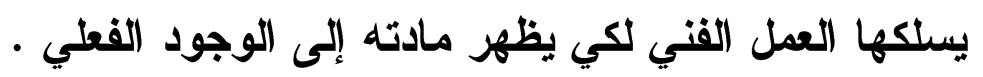
إن علم المعاني في دائرة البلاغة المركزية ليس دراسة جزئية لأواصر

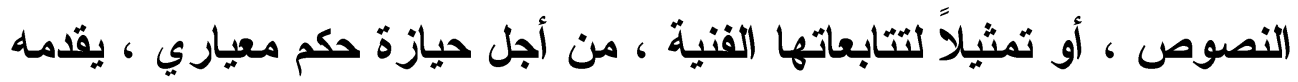

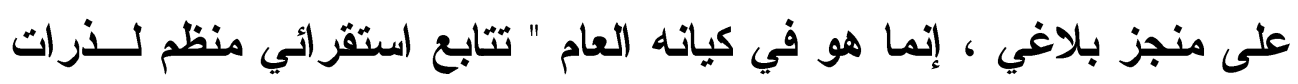

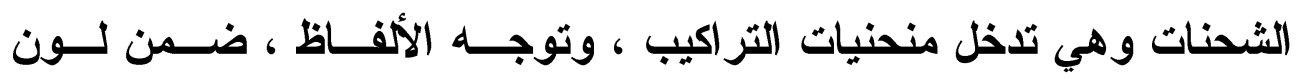

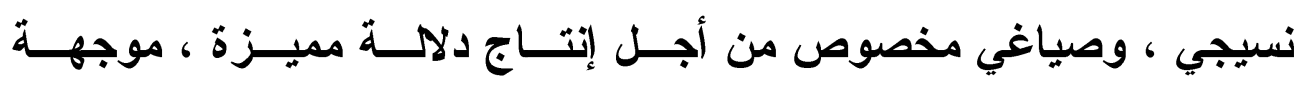

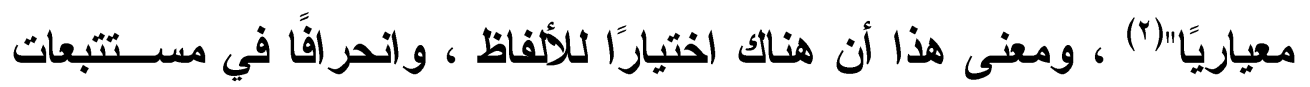

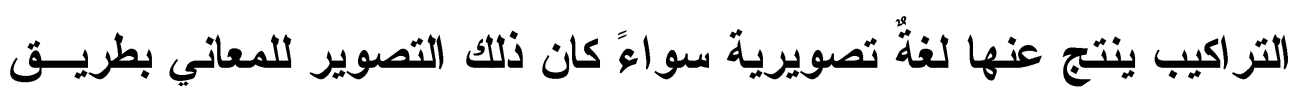

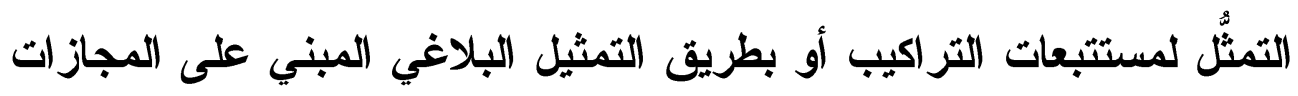

(1) الأسلوبية وثلاثية الدوائر البلاغية ، د. عبد القادر عبد الجليل ، ص: 9 ، 19 ، الطبعة الأولى،

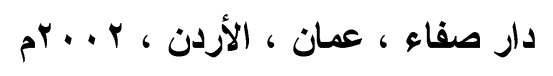

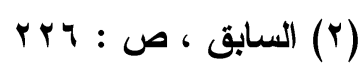


معنى المعنى خارج دائرة التمثيل البلاغي

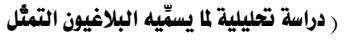

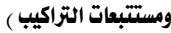

والاستعارات ، أو بهما معًا ليكونّن الثاعر أو الكاتب من خلاهما خطابًا أدبيًا تصويريًا للمعاني والأفكار والمشاعر والأحاسيس التي يسعى إلى إيصــالها

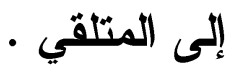

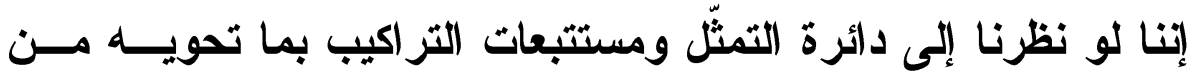
استشهادات بالشعر ، أو تضمين له ، أو الاقتباس من آيات القرآن آن الكريم ،

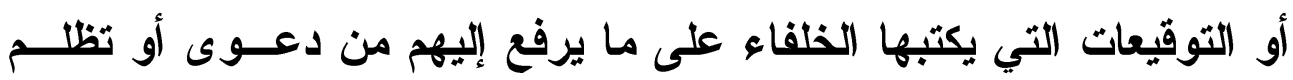

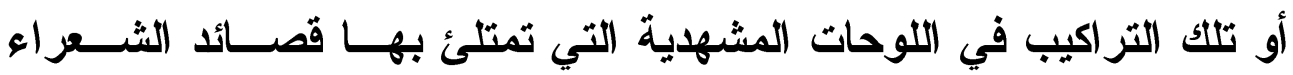

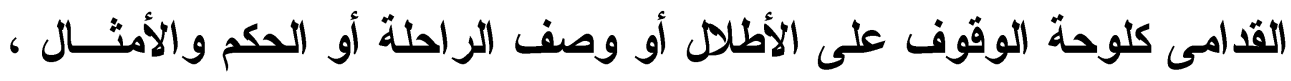

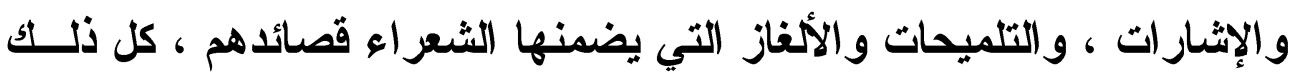

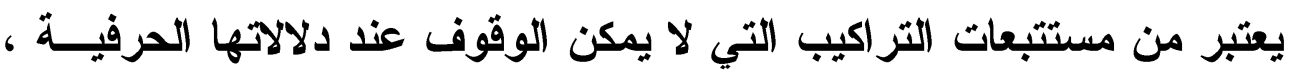

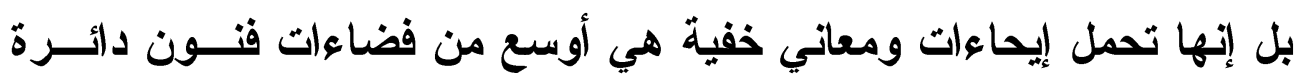

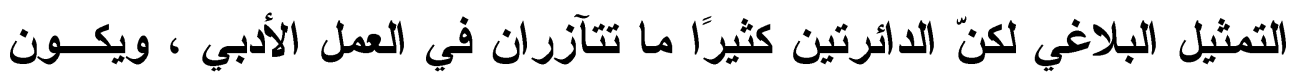

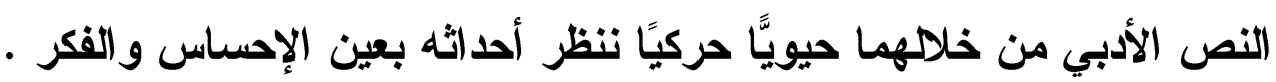
ولنأخذ على سبيل المثال قصيدة المتنبي التي يقول فيها ('):

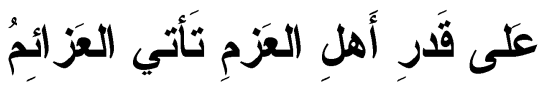
وَتَأتَي عَلَى قَرَرِ الكِرامِ المكَارِمُ

\section{وتَعظُُ في عَين الصنَغير صِغارُها}

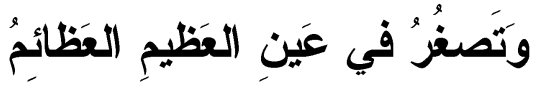

(1) ديوان المتنبي بشرح العكبري ضبطه وصحده ووضع فهارسه مصطفى السقا، إبـر اهيم

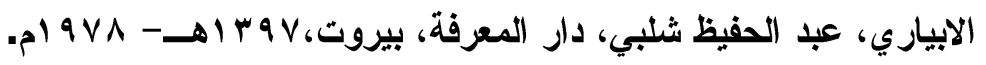

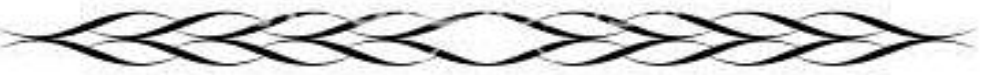




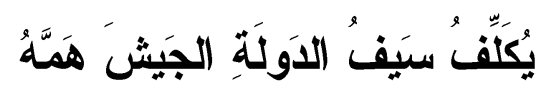

وََََ عَجَزَتَ عَنهُ الجُيُوشُ الخَضارِمُ

\section{وَيَطِبْ عِندَ النتاس ما عِنَ نَفسيهِ}

وَذََلَكَ ... مالا تَدَّعيهِ الضرَ اغِمُ

استهلّ المُتنبّي قصيدته بغرض شعري جميل وهو الحكمــة، وبــــأها بعزيمةٍ تشحذ الهمم، وذلك بما يليق باستقبال المظقر سيف الدولة الحمدانيّ،

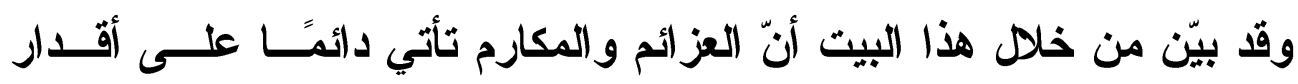
فاعليها، ويُقاس مبلغ هذه العزائم بمبلغهم، فعندما يكونوا عظامًا تكون هـي هـي عظيمة ، وانظر كيف بنى حكمته تلك على التقديم والتأخير ليعطي خصوصية لممدوحه ، وكأن العز ائم والمكارم مقصورة عليه دون غيره ، ثم يقدّم لنــا تلكك الشخصية القوية المتفردة التي تصغز في عينها العظائم في الوقت الأي تعظم في عين الحقير الصغائر ، ثم يستطرد في تصــوير تثـــ الشخصــية القيادية العظيمة التي تعجز عن همتها الأسود الهصورة .

$$
\text { هلِ الحَدَثُ الحَمَر اهُ تَعَرِفْ لَونَهَا }
$$

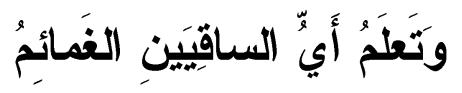

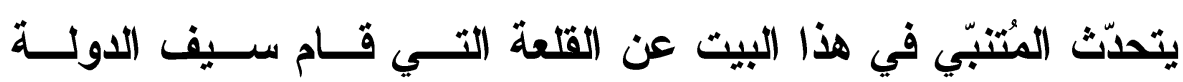
الحمداني ببنائها، وكان الرّوم قد غلبوا عليها وتحصنوا بحصنها، فجـــاءهم

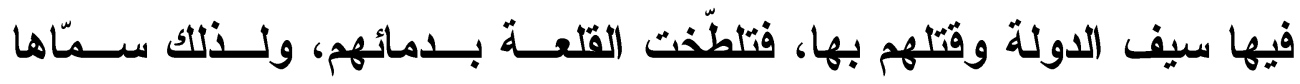

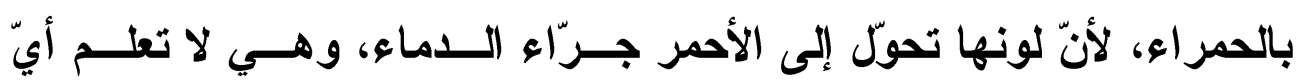
الساقين لها، أهو الغمائم وجماجم الرّوم أم السحائب في السماء؟. 
يوضتح الثاعر في هذا البيت معنى البيت الأي سبقه، ويقول إنّ قلعة الحدث قد سقتْها الغيوم في السماء مطرًا قبل بـاء المعركة، لئسأتي الأميـر سيف الاولة ويسقيها بعد المعركة جُثنًا وجماجمًا ودماءًا. بَّاها فَأَعلى وَالقَتَا تَقَرَعُ القَتا

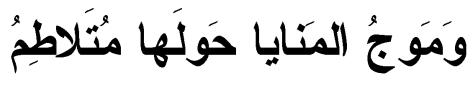

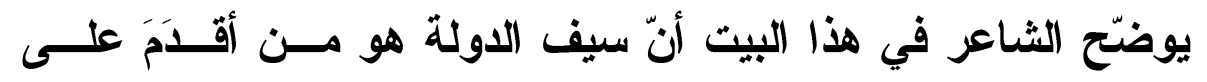

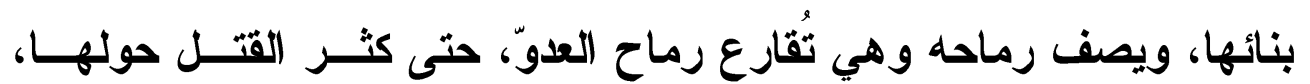
وكاتت المنايا كالبحر الأي يتلاطم وجهه. وكانَ بِها مِثِلُ الجنُونِ فَأَصبَحَتَ

وَمِن جُتَثْ القَتَلى عَلَيها تَمَائمُ

أراد بما كان فيها من الجنون والفتنة من الروم الذين كــانوا يـأتون

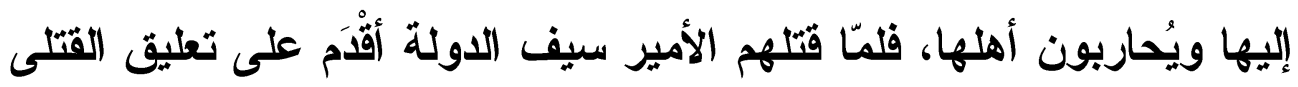

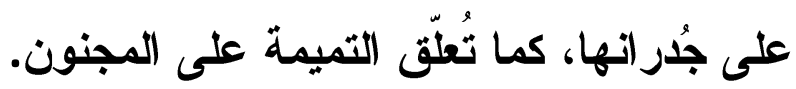
ففي الأبيات السابقة ترى أن التصوير تم عبر مستتبعات التزاكيب على أنى اختلاف أنواعها ، بينما كان حضور فنون دائرة التمثيل قليلة جدًا ، وكـأن

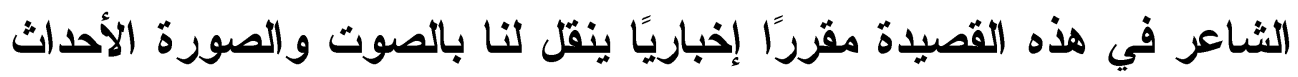

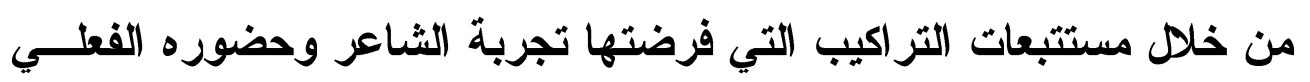


في المعركة لينقل لنا من خلال ألفاظه وتر اكيبه البديعة لوحة الاتتصار التـي رسمها المتنبي شعرًا .

والتضمين من فنون دائرة التمثل : فالنص ليس ذاتًا مستقلة أو مسادة موحدة، فالكاتب حين يكتب يرتكز إلى مخزون ثقافي مُتنوع نكون من خلال

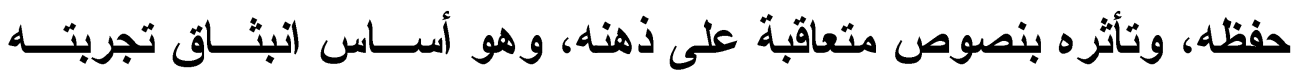

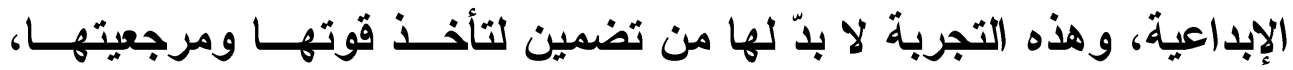
فالتضمين في علم البلاغة هو أن يُتبت الثـاعر أو الكاتب شيئًا مـنـ كــلام

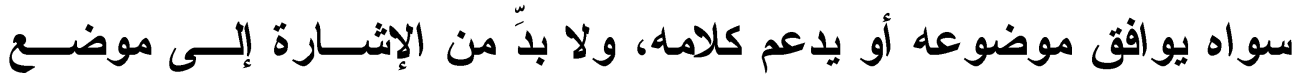

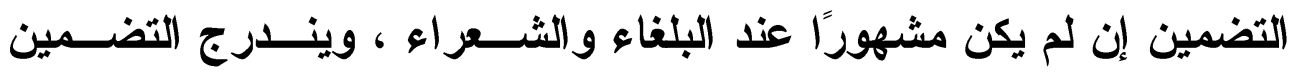
ضمن علوم البلاغة العربية تحت علم البديع، وهو من البديع المعنوي الأي

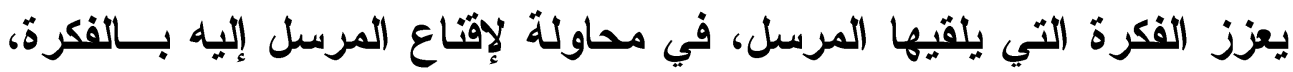
ولإعلام المرسل إليه بأن هذه الفكرة قد وافقت أفكار الآخرين.

وقال ابن رشيق " فأما التضمين فهو قصدك إلى البيت من الثــعر أو القسيم فتأتي به في أواخر شعرك أو في وسطه كالمتمثل، نحو قول محمــود بن الحسين كشاجم الكاتب: يا خاضب الثيب والأيام تظهره

هذا شباب لعمر الله مصنوع

$$
\text { أنكرتني قول ذي لب وتجربة }
$$

في مثله للك تأديب وتقريع

$$
\text { إن الجديد إذا ما زيد في خلق }
$$

تبين الناس أن الثوب مرقوع

\section{0}


فهذا جيد في بابه، وأجود منه أن لو يكون بين البيــــ الأول والآخـر

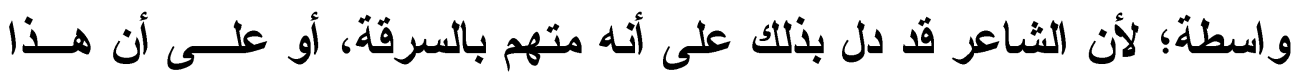

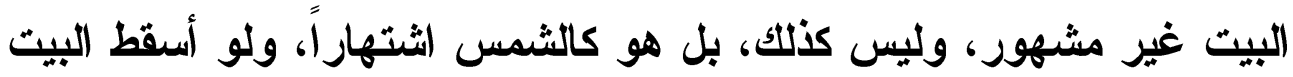

(الأوسط") (1)

وفي النقد الحديث دخل مصطلحا (الاقتباس و التضمين) تحت مصــطح

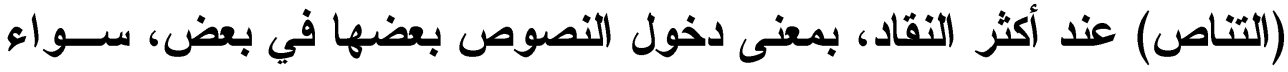

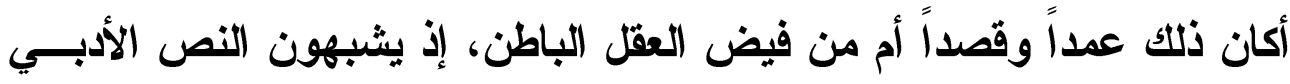
(بالفسيفساء) التي تتكون من عدة أحجار وألوان بثكل منسق جميل يمنحها

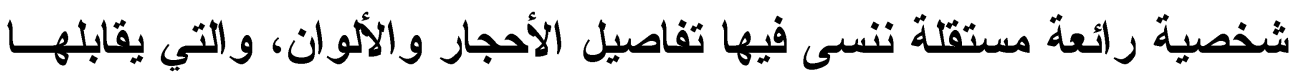
في الثعر الألفاظ و الصور.

إن معنى المعنى يمكن أن يحققه الثاعر أو الأديب بفنٍ أوسع بابًا من دائرة التمثيل البلاغي ، وإنما يكون ذلك من خلال باب التمثــل ومســتنبعات

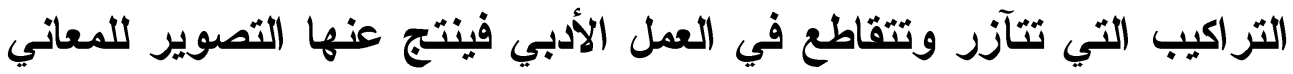
في غاية البلاغة والدقة في التعبير كما أن التمثل بالثُعر وغيره ، ومراعاة

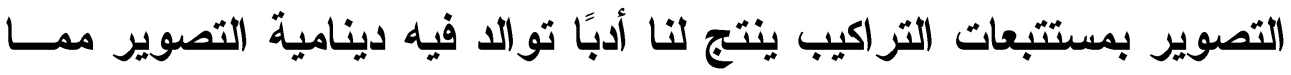

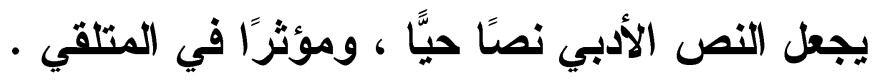

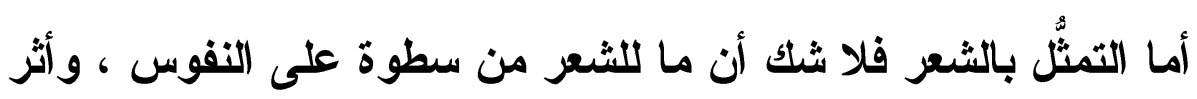

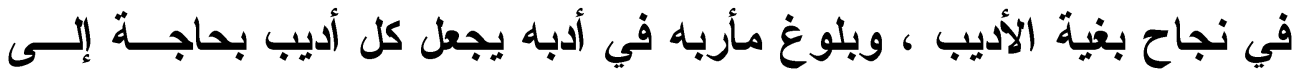

(1) العدة في محاسن الثعر وآدابه لابن رشيق القيرواني ، جز/ عه ، تحقيق: محمد محيي

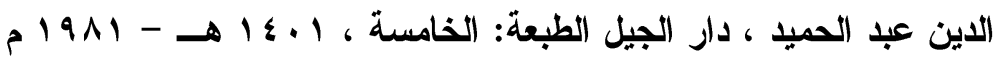


التمثل به لما له من الأثر البالغ في النفوس ، ولا شك أن كلَّ بليغ بحاجــة

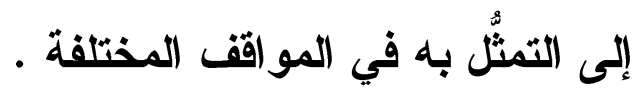

هذا نبينا محمد عليه الصلاة والسلام يُروى عنه التمثل ببعض الثـــر

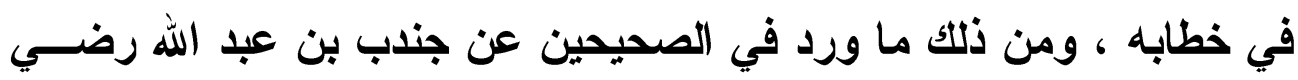

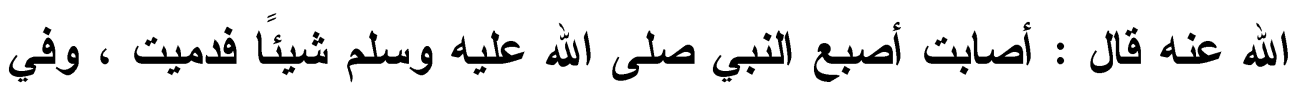

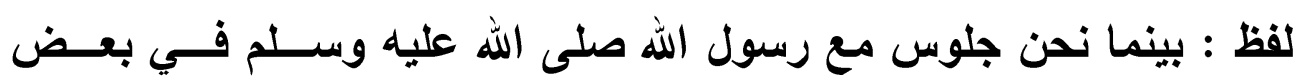
المشاهد إذ أصابه حجر ، فدميث أصبعه فقال :

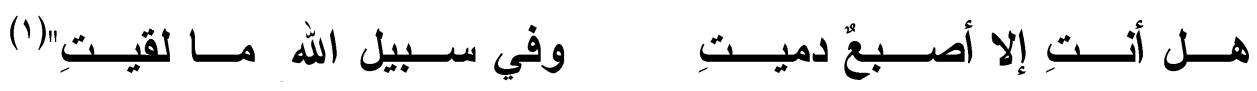
والبيت من شعر عبد الله بن رواحة تمثل به صلى الله عليه وسلم في

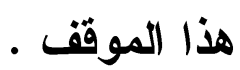

وكان عمر بن الخطاب رضي الله عنه يتعبب من معرفة زهير بن أبي

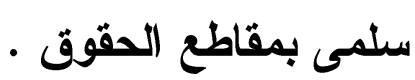
وقال ابن هثام رحمه الله :" لما سمع عمر بن الخطــاب رضــي الله

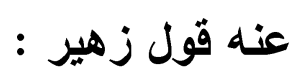

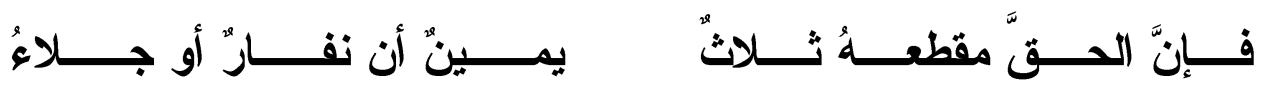

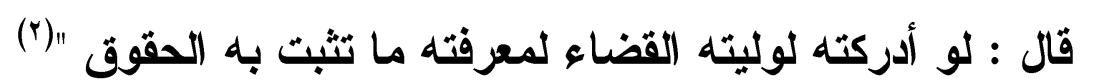

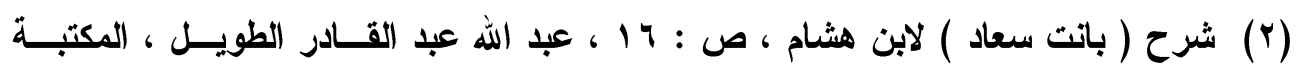

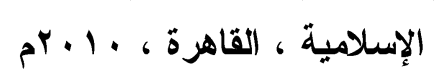


معنى المغنى خارج دائرة التثثيل البلاغي

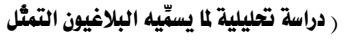
ومستتبعات التراكيب )

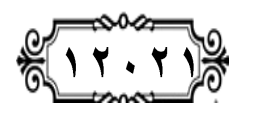

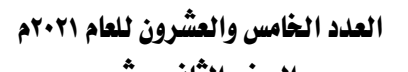

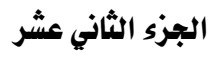

وربما ضمن الثاعر قوله شعر غيره ، ونقله من معناه الأي وضع لله

إلى معنى جديد كما في قول الأخيطل(') :

ولقد سما للخرِّـــي فـــم يقـلن بعد الوغى : لكن تضايق مقدمي

فقوله : تضايق مقدمي لعنترة بن شداد حيث قال :

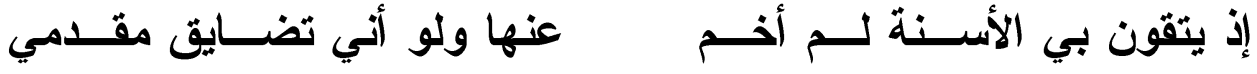

وقد يكون التمثُّل ببعض بيث من الثعر كما في قول الثاعر () :

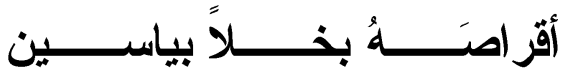

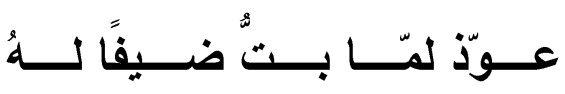

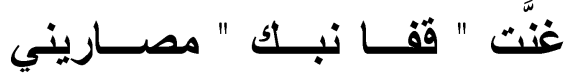

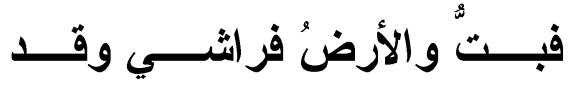

ولا يخفى تمثّل الثاعر بجزء من بيت امرئ القيس :

ققا نبك من ذكرى حبيب ومنزل بسقط اللوى بين الاخول فحومل

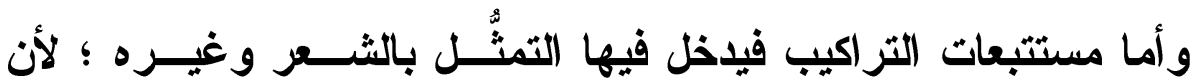

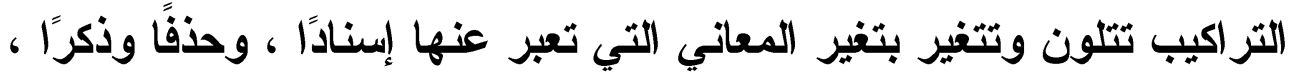

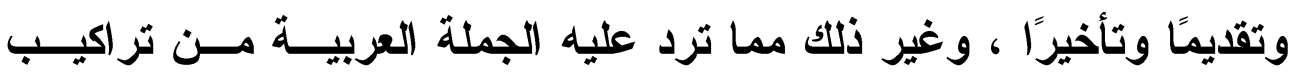

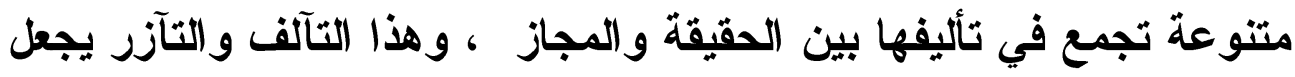

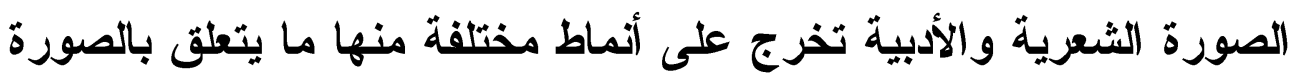
الاستعارية أو البلاغية في دائرة التمثيل البلاغي وتأتي على ثلاثة أنـــواع : الصورة الجزئية ، الصورة المركبة ، الصورة الكلية .

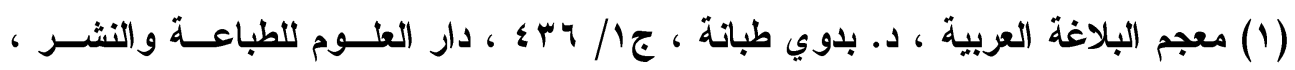

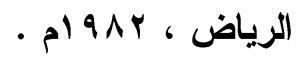

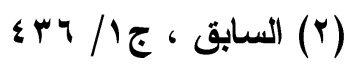

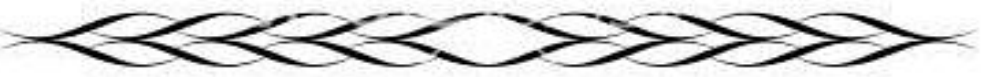




\section{الترقيه الدوله 2356-9050

و هذه الأنواع الثلاثة تتآلف مع الصورة اللغوية التي تتولد داخل دائرة

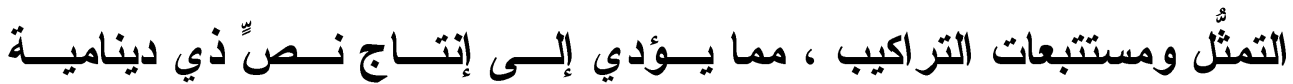
تصويرية حية .

\section{أولاً : أنهاط الصورة الأدبية في دائرة التمثيل البلاغي :}

أ. الصورة الجزئية : وتبرز هـــه الصــورة المفــردة فــي التثــبيه

والاستعارة ، وهي - من وجهة نظر الباحث - من المكونات الأولى للصورة

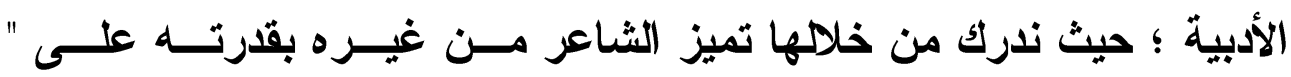

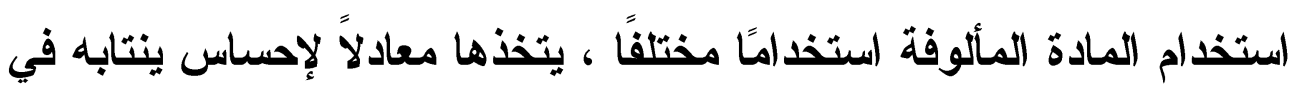

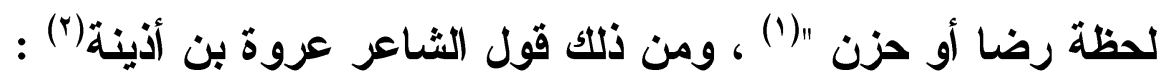
كشمس الضحى تحت أســتارها

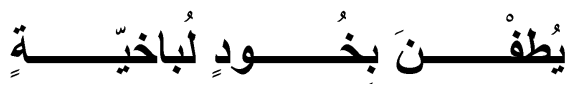

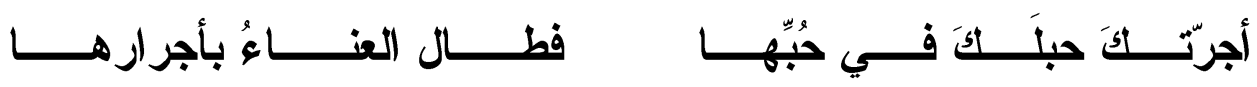
حيث شبّه صفاء لون المرأة الثابة التامة الطول بالثمس لالالة بقاء

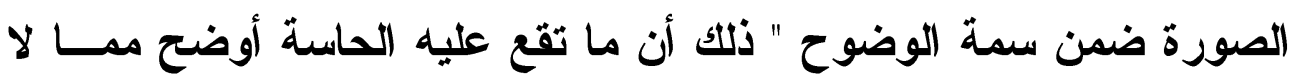

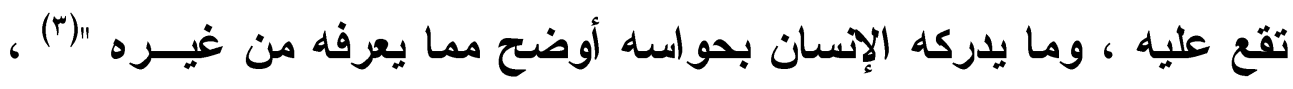

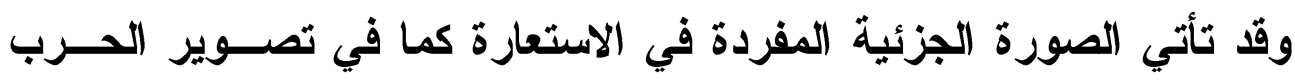

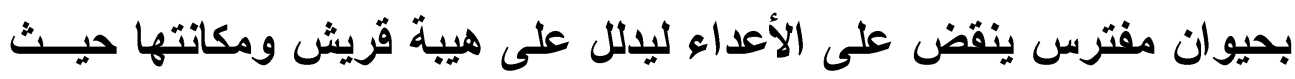

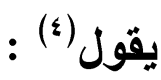

(1) الصورة الفنية في شعر ابن دراج القسطلي ، ص: 9 ب ، أثرف دعدور ، مكتبة الثرق ،

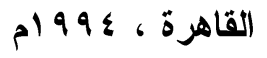

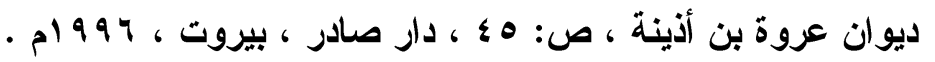

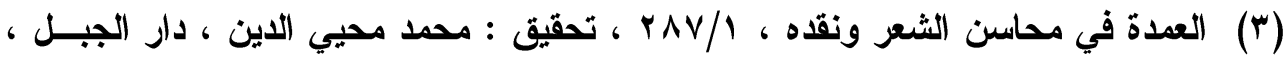

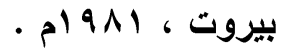

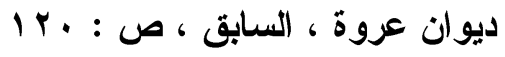


معنى المعنى خارج دائرة التمثيل البلاغي

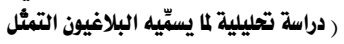
ومستتبعات التراكيب )

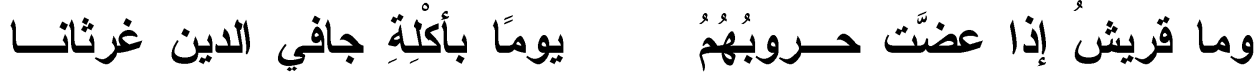

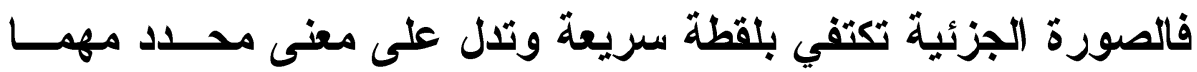
يكن غناها الرمزي والإيحائي ، لكنها تعتبر نواة التصوير في دائرة التمثيل . ب. الصورة المركبة : وهي تختلف عن الصورة الجزئية المفردة فـي كونها تثبيه مركب أو تمثيلي " ينتزع من أمور مجموع بعضها إلى بعـض نهض

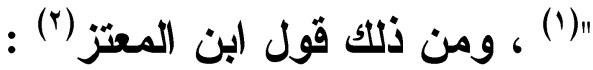

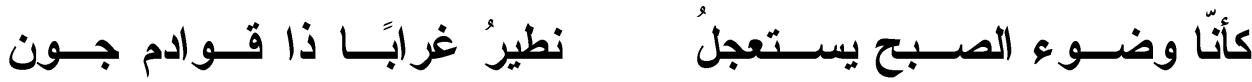
شبه ظلام الليل حين يظهر فيه الصبح بأثخاص الغربان ، ثم اثــترط أن تكون قو ادم ريشها بيضًا ؛ لأن تلك الفرق من الظلمة تقع في حواثيها ، وهذا من الاستقصاء الذي امتدحه البلاغيون في التثبيه. والصورة المركبة سلسلة من الصور الجزئية التي تتيح المجال لاتساع

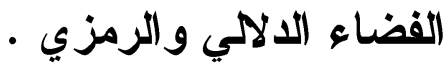

ج. الصورة الكليّة : تتضمن سلسلة مشاهد تصويرية ولا يمكن تحديد

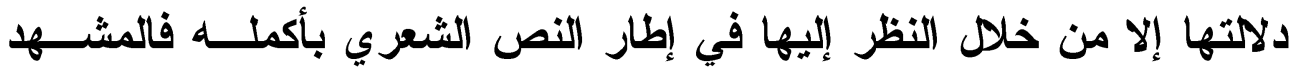

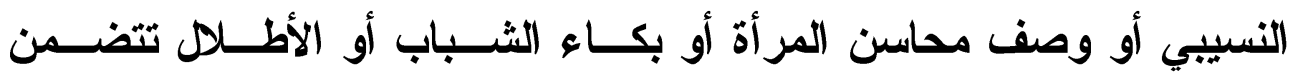
مجموعة صور جزئية تخضع لاختيار معيّن من القائل ، ولترتيب مقصــود ؛

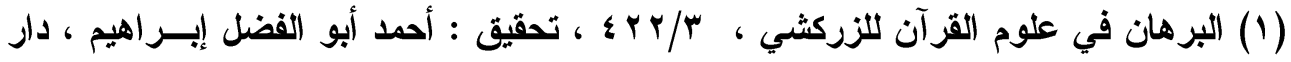

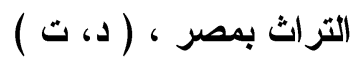
(ץ) ديوان (بن المعتز العباسي ، ص: ه ه ؛ ، ، تحقيق: د. محمد بـــيع شــريف ، دار المعـارف

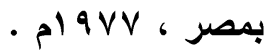

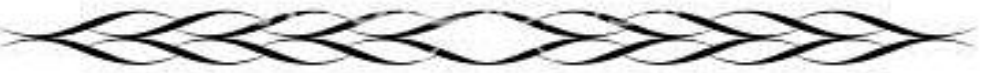


بحيث يتخذ المشهر أبعادًا وفضاءات واسعة ليست مجرد تقليد كمــ ســمّاه

بعض الارارسين (1)

ومن شواهد الصورة الكلية قول الأعثى (r) :

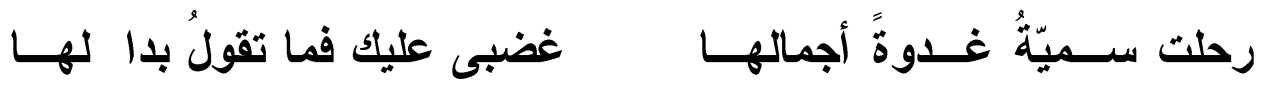

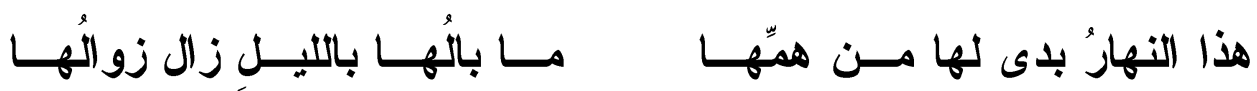

سفهًا وما تدري ســميةٌُ ويحهـــا أنْ رُبَّ غانيةٍ صرمت وصــالها

وسمية وغيرها من الأسماء التي وردث عند الثعر اء تأخذ بُعدًا إثاريًّا

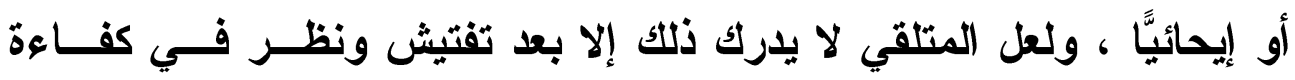
الثشاعر بتوظيفها في الاستعمال الشعري برمزيتها التي يتجاوز بهـــا عـالم الواقع لتحلّق في عالم الخيال والإيحاء " فهم كثيرًا ما يأتون بها زورًا ، نحو بردي ليلى وهند وسلمى وأثباههن "() ، لعلّ مقابلة الماضــي والحاضــر تثيــر

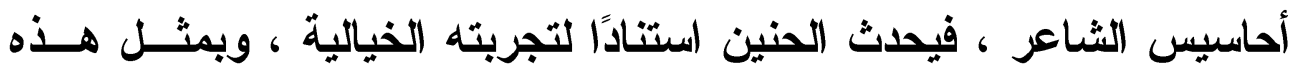
المقدمات في علاقات المحبوبة ببنية الصراع في الماضي تُـــرك الصــورة الشعرية الإثارية ، حيث إن مأساة القطيعة والقراق لا تتجلى فـي قطيعـة سمية أو غيرها من هذه الأسماء ، وإنما هي مأساة أكبر تتخطى عالم الذات التهري وتتجاوزه لتشمل الإنسانية عامة ، ولعل هذا النوع مــن الصــورة يقتــرب كثيرًا، بل يتحد ويمتزج مع الصورة اللغوية التي تثع أنوارها مــن دائــرة التمثُّ بمستتبعات التر اكيب كما سيأتي.

(1) الاتباع والابتداع في الثعر الأموي ، ص: ع V ، محمد المؤدب ، كلية الآداب ، تطــوان ،

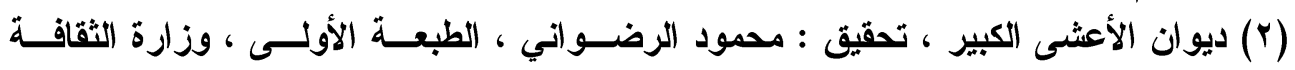

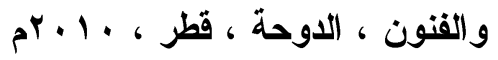

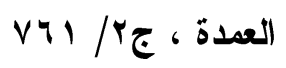


معنى المعنى خارج دائرة التمثيل البلاغي

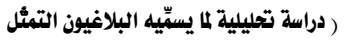
ومستتبعات التزاكيب )

ثانيًا : الصورة اللغوية في دائرة التـمثلُ ومستتبـعات التزاكيبب :

وهي الصورة التي يتم فيها التعبير بألفاظ اللغة و أساليبها ليس غير ،

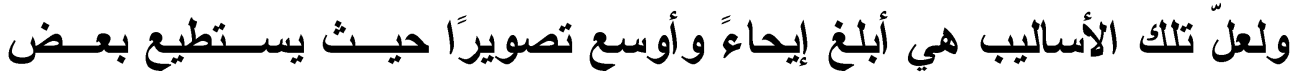
الشعر اء والكتّاب التقاط هذه الصورة بألفاظ معدودات .

ويمكن من خلال الصورة اللغوية تطوير فنون دائرة التمثيـلـل البيــاني بحيث نتجاوزها - دون مصادرتها بالطبع - إلى الكشف عن الرموز المتعددة للصورة بوصفها بنية واحدة ، وللعناصر الداخلة في تشكيل هذه الصورة . إن الصورة الأدبية تستدعي شحن كل تركيب وكل صورة بالإيحــاءات لتتجسد من خلالها روئة الأديب للكون والحياة والناس . إن عناصر الصورة الأدبية من صوت وحركة وضــياء ولــون هـي عناصر هذه الحياة التي يعد الأديب جزعًا منها ليلتحم الفكر مع التصوير في بنية و احدة .

وقد اختارت الار استة مشهدًا من مشاهد معلقة النابغة الــذبياني الــذي استعمل الصورة اللغوية وما تحتويه من أنواع صور التمثيل البياني ليقدم لنا لوحة شعرية قصصية تقوم على الفكر والتصوير ملتحمين في بنية واحدة . يقول النابغة(1) - 20

يوم الجليل على مسـتأنس وحِِ كأنّ رحلي وقد زال النهـــارُ بنــا طاوي المصير كسيفِ الصــيقل من وحش وجرةٍ موشيّ أكارعُهُ

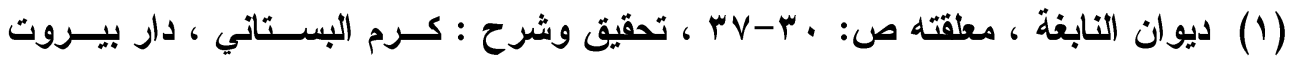

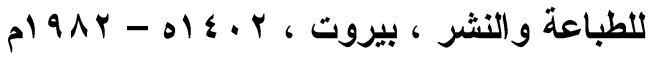

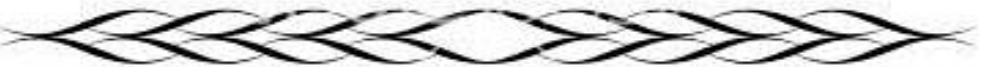


تزجي الثُمال عليه جامدَ البَــرَِّ

سرت عليه من الجوزاوِ ســاريةٌ

طوع الشوامت من خوفـٍ ومــن فارتاع من صوت كلاب فبات للهُ

صمحَ الكعوب بريئاتِ من الحَرَدِ

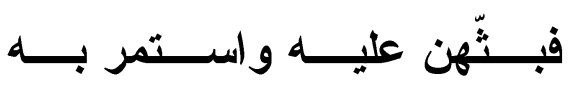
طعن المعارك عند المحجر النَّجدِ

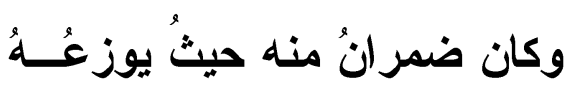
طعنَ المبيطر إذ يشفي من العَضَدَ شكتّ الفريصة بالمدرى فأنفـــها سفّود شرب نسوهُ عنـــــ مفتـــأدِ

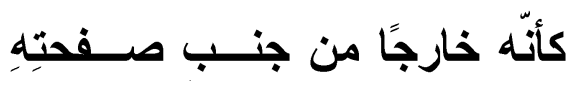
في حالكِ اللون صدق غيـر ذي فظلَّ يعجُمُ أعلى الرَّوق منقبضَّـا ولا سبيلَ إلــى عقــل ولا قــوكَ

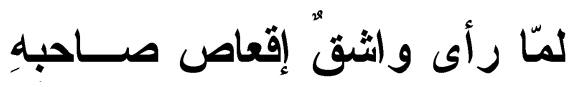

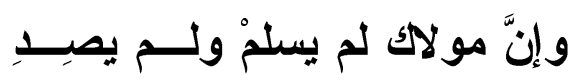
قالت لله الــنفسُ : إنــــ لا أرى فضلاً على الناس في الأدنى وفي

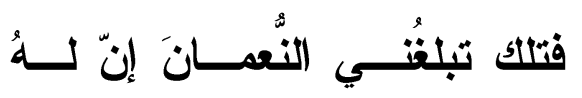
فالثشاعر يثبه رحله بوحش وجرة ، ويستغرق في تفصيل المشبه بـــه

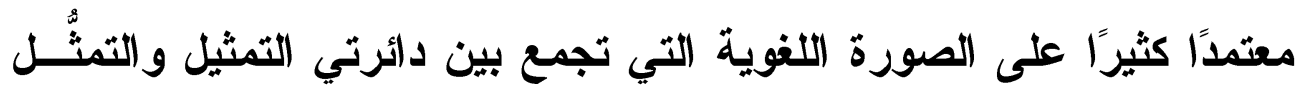

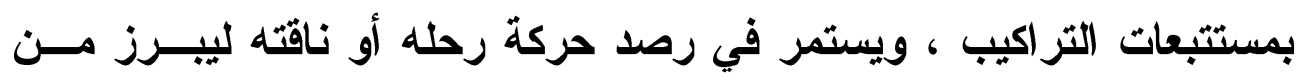

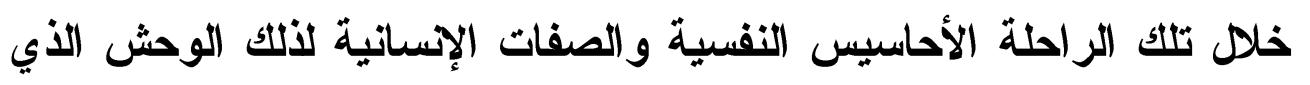

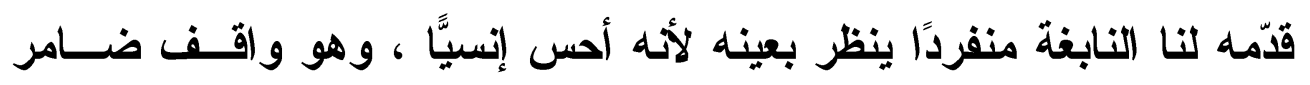

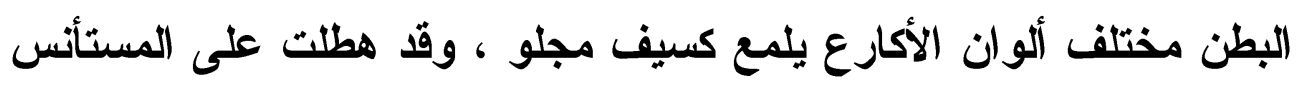

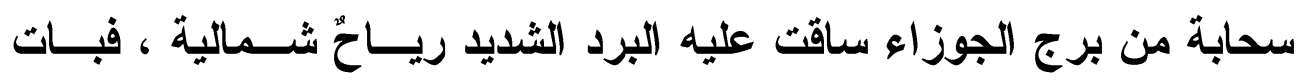

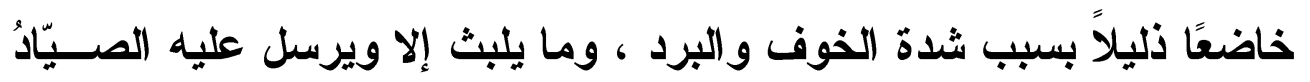

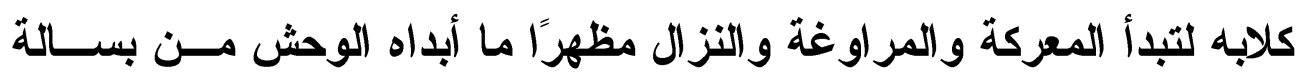
ضد تلاك الكلاب التي ذهبت منكسرة مهزومة أمامه . 
ويعود السبب - من وجهة نظر هذه الدراسة - في امتداد هذه الصورة

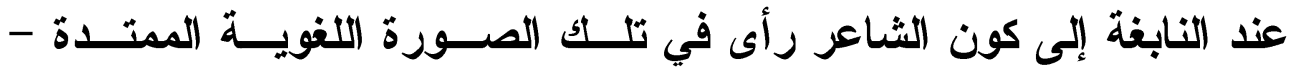

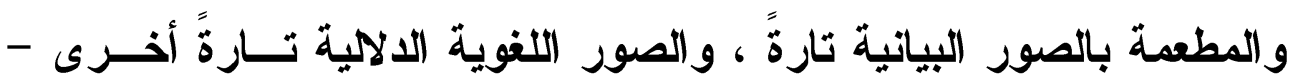

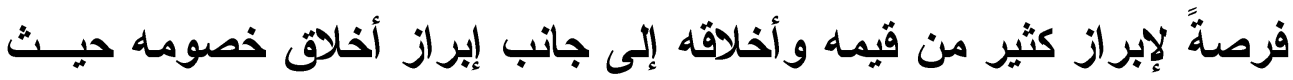
عطف إلى التفصيل في صورة ذلك المشهد الطبيعي الذي اعتبره مادة خصبة

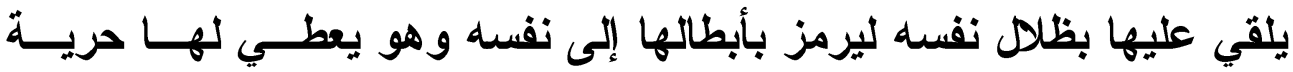

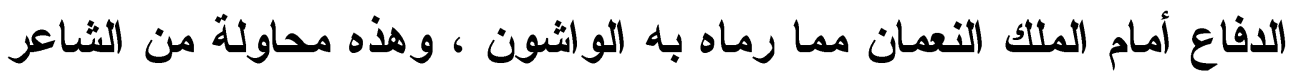

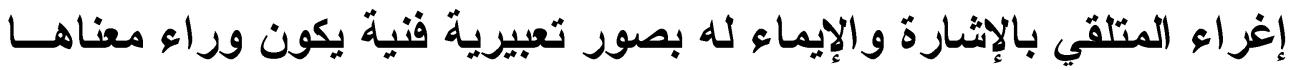

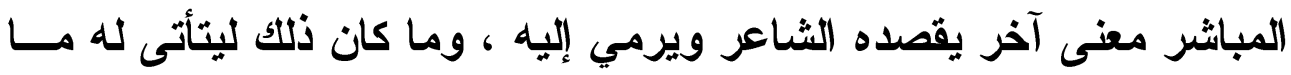
لم يمزج في تصويره بين دائرتي التمثلّ و التمثيل . 


\section{الخاتهة}

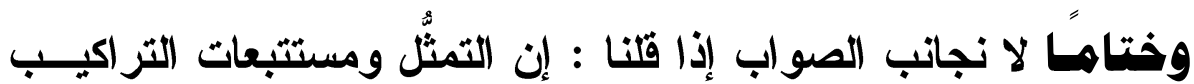
التي يعبر عنها اليوم بالأسلوبية ، والتي تمثل الوجه الثاني للبلاغة القديمة؛

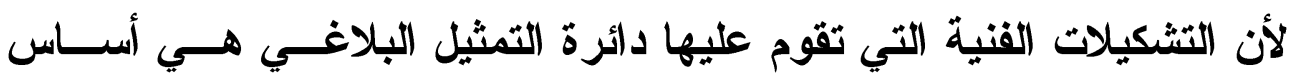
الارس الأسلوبي ، ولكن بطريقة مختلفة تتجاوز الناحية الثكلية إلى دراسة

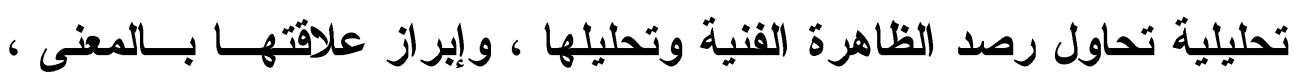
وهي ملاحظة أثثار إليها السكاكي في معرض حديثه عن علم البيـان " وإذا

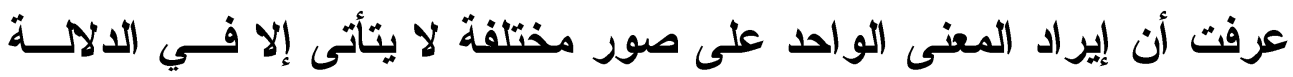

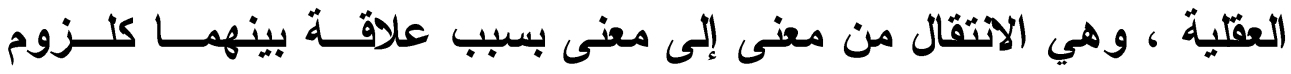

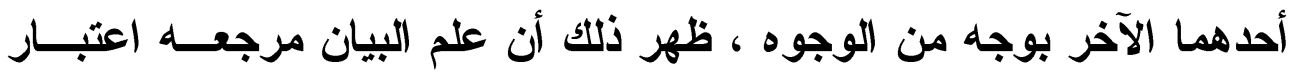

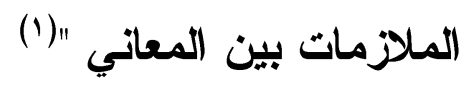
إن تثكيلات الصور البيانية ربما تتجاوز ظــاهرة التثـكيل اللغــوي المباشر إلى الملازمات التي تصاحب اللغة ، وتنقل السامع من اللغة العادية

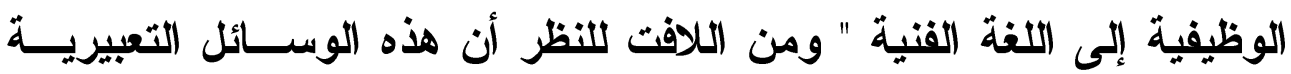
الموروثة أصبحت - بثكل أو بآخر - إحدى مجالات الدراســة الأســلوبية

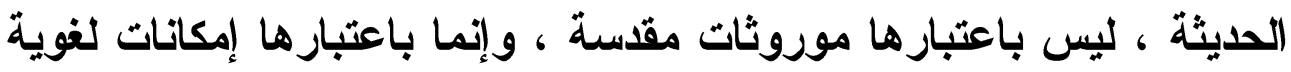

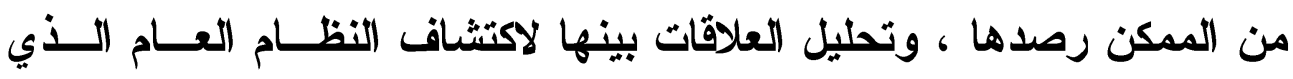

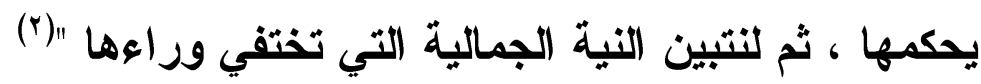

(1) مفتاح العلوم للسكاكي ، ص : بّ ، ، تحقيق : نعيم زرزور ، الطبعة الأولـى ، دار الكتب

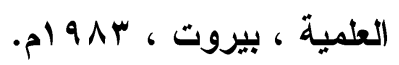

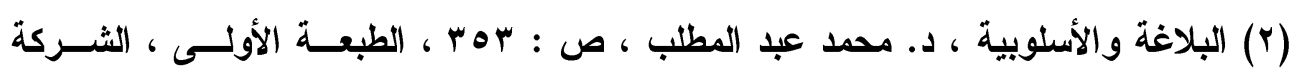

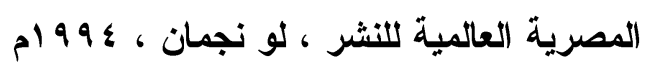


معنى ذلك أن دائرة التمثيل البياني تثناول الجانب الجمالي من خــلال التركيب اللغوي ، وهو ما تلتقي فيه دائرة التمثيل البلاغي البياني مع دائرة

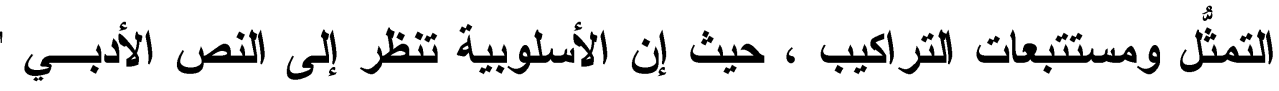

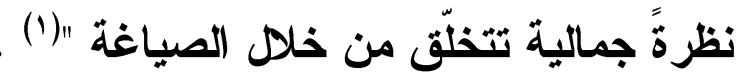

ونستنتج مما سبق أن التصوير في تلك الفنون جميعها يحكمه الــنظم و السياق ومستتبعات التزاكيب " فقيمة اللفظ لا في كينونته الأتية ، و إنما في

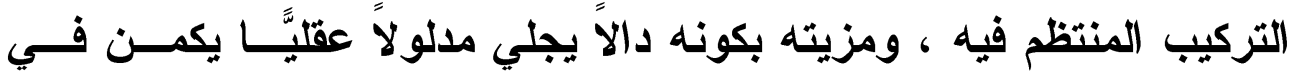
خاصته الأسلوبية على الرغم من تماثل صيغة الإسناد الثكلي في اللغة الي

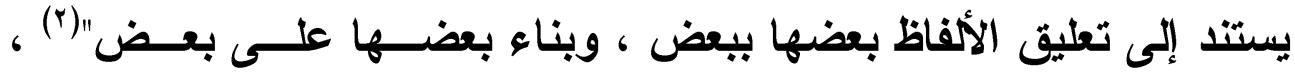
ولذلك يجب النظر إلى " العمل الأدبي بوصفه وحدة ، و إلى موقف الثـــاعر في تجربته ، وفي هذه الحالات تكون طرق التصوير الثعرية ســائل جمــال فني مصدره أصالة الكاتب في تجريته وتعقه في تصويرها ، ومظهره فـي

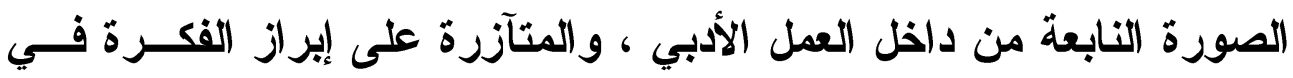

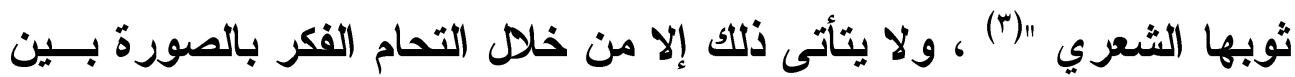

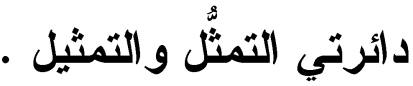

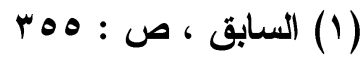

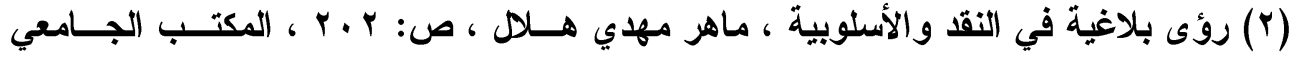

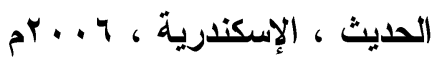

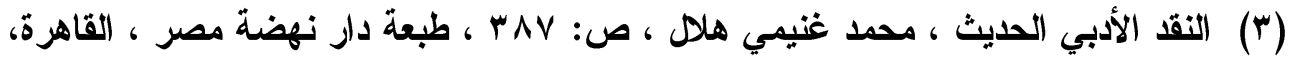




\section{ISSN 2356-9050 الترقيه الدولي

\section{ومن أبرز التوصبات التي توصي بـها هذه الار اسة ما بليـ :}

ا ـ إن تصوير الفكر والمعنى ليس مقصورًا على دائرة فنون التمثيل البياني في البلاغة العربية ، وإنما يقوم إلى جاتب هذه الدائرة ويلـــــم معهــــا دائرة التمثُّ ومستتبعات التر اكيب التي لا تقل أهمية أيضًا . r. دائرة التمثُّ ومستتبعات التراكيب قد تكون أوسع مجالاً ورحابــةً فـي التصوير كما أثبتت هذه الار اسة .

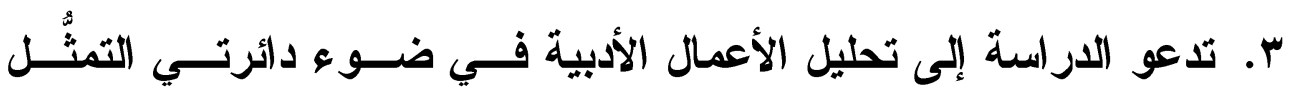
والتمثيل حيث إن كلاهما يمثلان تصوير المعنى جنبًا إلى جنب . ع. إنّ مستتبعات التركيب مليئة بشحنة هائلة من تصوير المعاني والأفكار ، وهذا ما فطن إليه علماء اللغة والبلاغة من زمن طويل . هـ قدّم الشعراء الأوائل قصائد ذات لوحات مشهدية رائعسة جمعـت فـي تصوير المعنى بين دائرتي التمثل والتمثيل وقدمت معنى المعنسى مسن خلال تلك اللوحات القنية بقدرة عالية تعكس ظلال النفس ، ومكنونـات القكر - الق

7 ـ تحث الدراسة الباحثين على البحث في دائرة التمثل ومستتبعات التر اكيب فهي دائرة غنية ما زالت بكرًا وما زالت فنونها الكثيرة دفينة تحت ركام العجمة التي يحاول أصحابها إبعادنا عن كنوز بلاغة لغة القرآن الكريم.

والله أسأل أن يتقبل مني بحثي هذا ، ويجعله خالصًا لوجهه تعالى ، والحمد لله رب العالمين . 
معنى المعنى خارج دائرة التمثيل البلاغي

( دراسة تحليلية لما يسقيّيه البلاغيون التمثئل

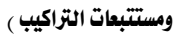

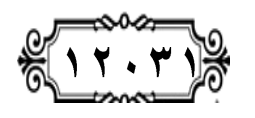

العدد الخامس والعشرون للعام الب.r.

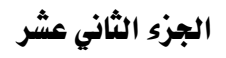

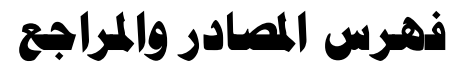

$$
\begin{aligned}
& \text { • القرآن الكريم } \\
& \text { • الحديث الثريف ل }
\end{aligned}
$$

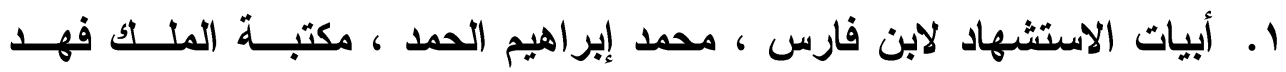

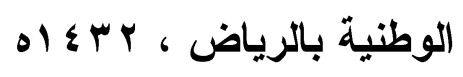

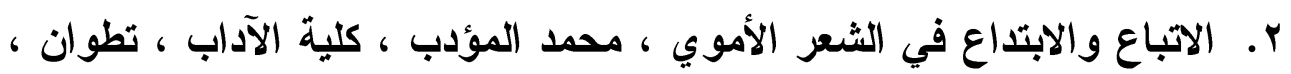

$$
\text { - r..r }
$$

r. الأدب المفرد للبخاري ، تحقيق : محمد فؤاد عبد الباقي ، المطبعة السلقية ، .01 TVO

ع. الأسلوبية وثلاثية الدوائر البلاغية ، د. عبد القادر عبــــ الجليـل ، الطبعـة

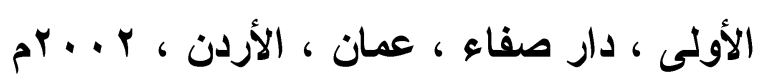

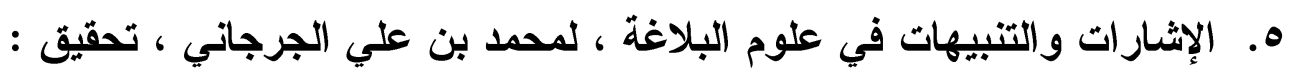

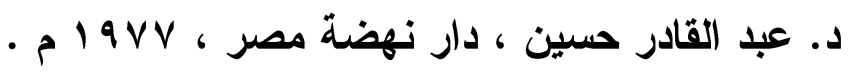

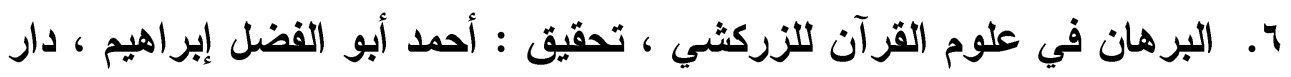

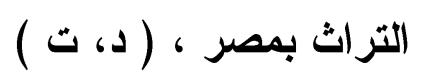

V. البلاغة العربية أسسها وعلومها فنونها للميداني ، الطبعة الأولى ، دار القلم،

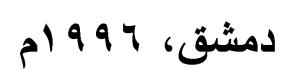

^. البلاغة والأسلوبية ، د. محمد عبد المطلـب ، الطبعـة الأولـى ، الثــركة

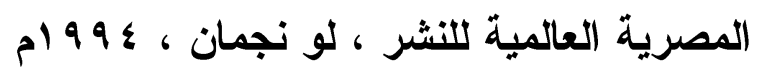

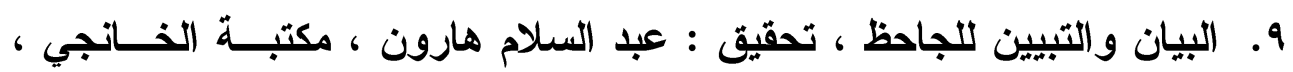

$$
\text { - 1991 }
$$

• 1. التفسير النفسي للأدب ، عز الدين إسماعيل ، الطبعة :؛ ، مكتبة غريب ،

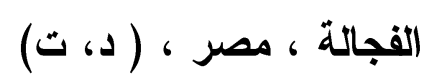

11. تقريب منهاج البلغاء وسراج الأدباء ، تحقيق : محمد أبو موسى ، مكتبــة 


$$
\text { وهبة ، }
$$

r 1. الحيوان للجاحظ ، الطبعة الثانية ، دار الكتب العلمية ، بيزوت ، ع ع ع اه ـ. r ا. دلائل الإعجاز ، عبد القاهر الجرجاني ، تعليق محمود محمد شاكر ، مطبعة

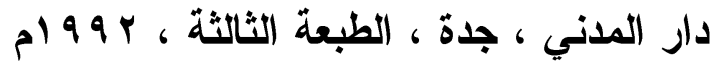

ع ا. دلائل الإعجاز في علم المعاني لأبي بكر الفارسي ، تحقيق : محمود شاكر ،

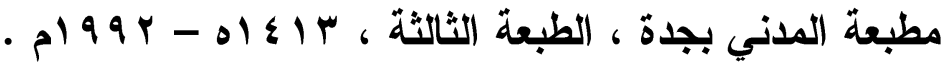
ه ا. ديوان ابن المعتز العباسي ، تحقيق: د. محمد بايع شريف ، دار المعــارف

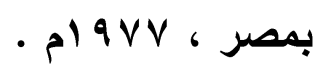

17 ا. ديوان الأعشى الكبير ، تحقيق : محمود الرضواني ، الطبعة الأولى ، وزارة

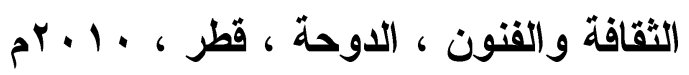

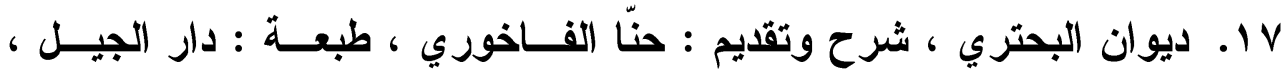

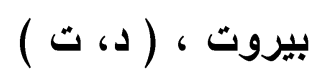

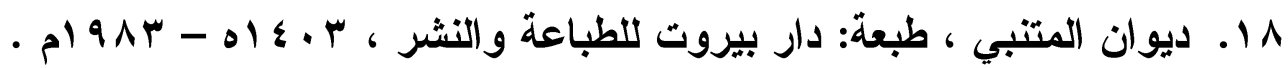
9 1. ديوان المتنبي بشرح العكبري ضبطه وصححه ووضع فهارســه مصـطفى

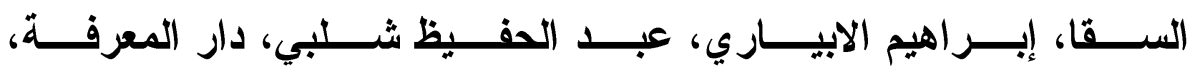

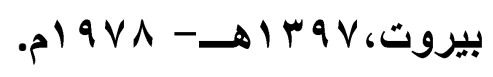

• †. ديوان النابغة ، معلقته ، تحقيق وشرح : كــرم البســتاني ، دار بيـروت

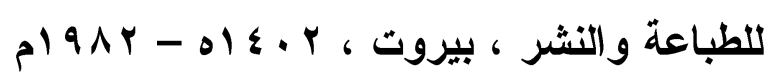

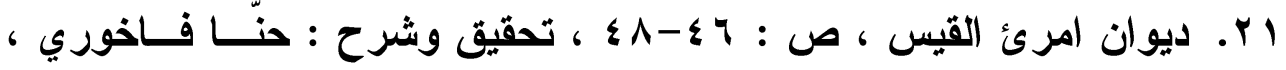

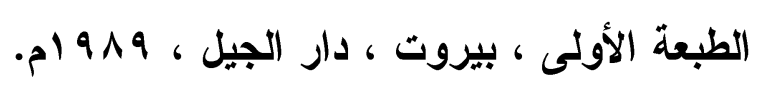

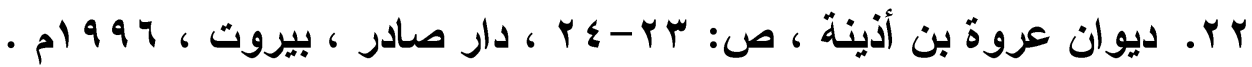
rr. ديوان قيس بن الملوح ، تحقيق : يسري عبد الغني ، طبعة : دار الكتـبـ

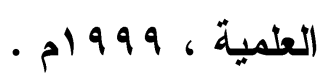

ع r. ديوان كعب بن زهير ، تحقيق : علي فاعور، دار الكتب العلمية، و99 ام. 
معنى المعنى خارج دائرة التمثيل البلاغي

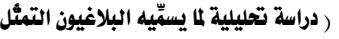

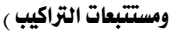

ه . . رؤى بلاغية في النقد والأسلوبية ، ماهر مهدي هلال ، المكتب الجـامعي

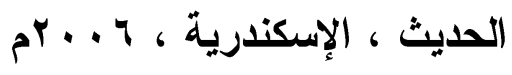

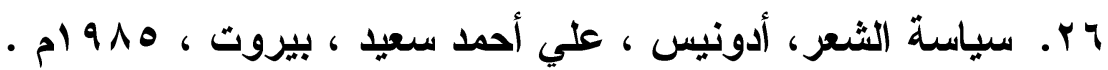
rV . . شرح ( باتت سعاد ) لابن هشام ، عبد الله عبد القادر الطويـلـل ، المكتبــة

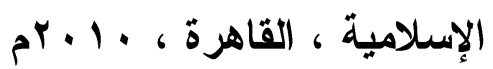

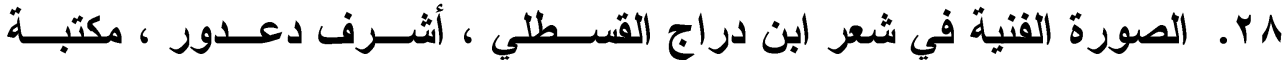

$$
\text { الشرق، القاهرة ، ع } 99
$$

و ب. الصورة في الثعر العربي حتى القرن الثاني الهجري دراسة في أصــولها وتظورها ، د. علي البطل ، الطبعـة الأولــى ، بيــروت ، دار الألــلس ،

$$
\text { - pl } 91 \text {. }
$$

• r. العربية والغموض ، حلمي خليل ، دار المعرفــة ، الإســكندرية ، الطبعـة

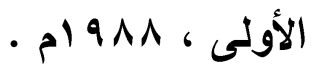

اس. العمدة في محاسن الثعر وآدابه لابن رشيق القيرواني ، تحقيـق: محمــ

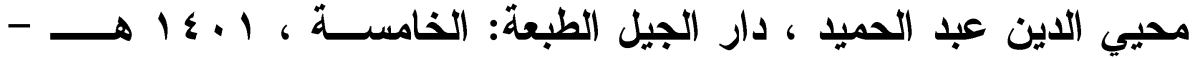

$$
\text { ? } 19 \wedge 1
$$

r r. العمدة في محاسن الشعر ونقده ، تحقيق : محمد محيي الاين ، دار الجبل ،

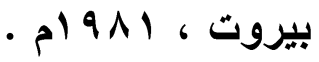

rr. غرر الخصائص الواضحة وعرر النقائض الفاضــحة للوطــواط ، ضــبطه وصححه : إبراهيم شمس الدين ، الطبعة الأولى ، دار الكتـبـ العلميــة ،

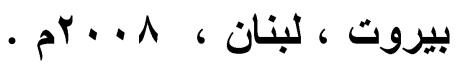

ع س. فتح الباري شرح صحيح البخاري ، لابن حجر العسقلاني ، تحقيق: محمــ

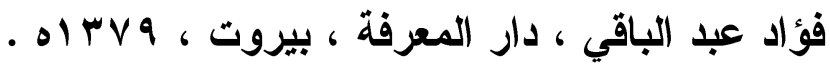
هـ. قر اعة في الأدب القديم ، د. محمد أبو موسى ، الطبعة الثانية ، مكتبة وهبة 
צr. لسان العرب لابن منظور ، دار الكتب العلميّة، بيروت، طا، ( د، ت ) .

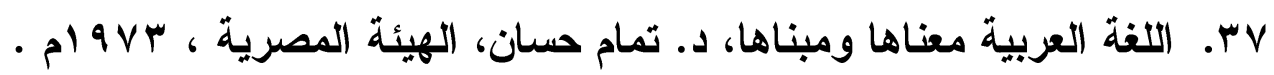

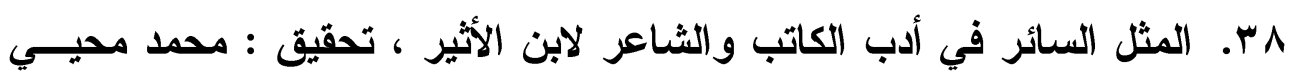

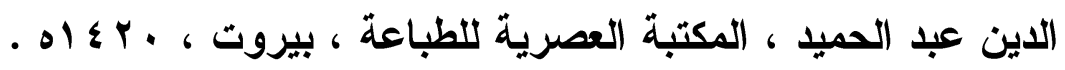

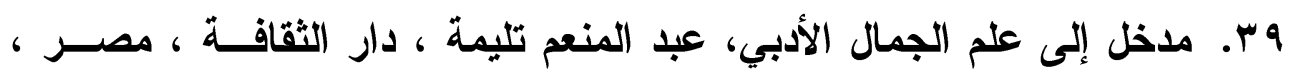
- م) $9 \vee \wedge$ • ع. مستتبعات التراكيب القرآية عند ابن عاشور في تفسيره ، د. مقبول بشير

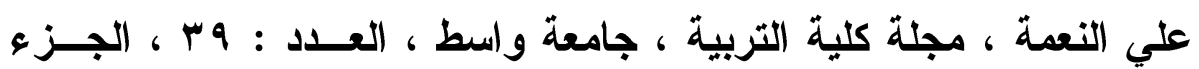

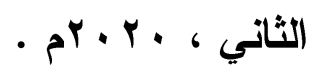

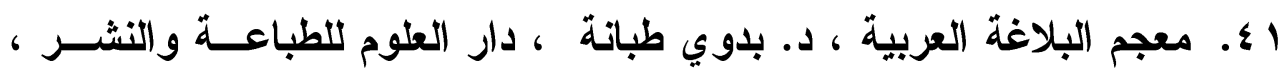

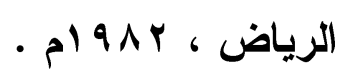

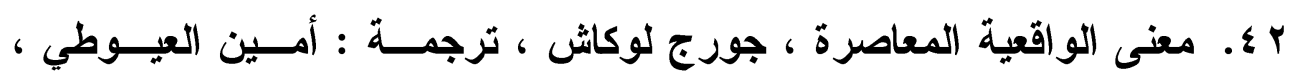

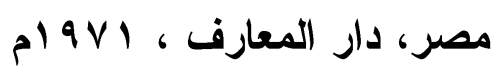

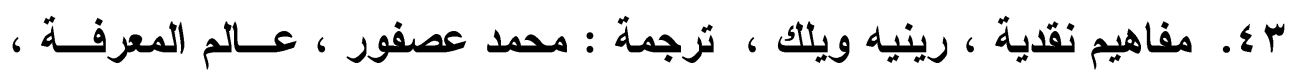

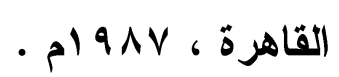

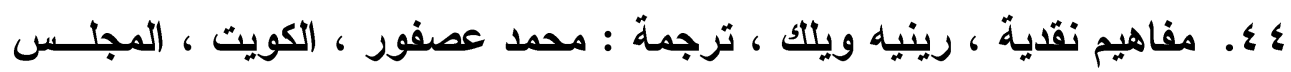

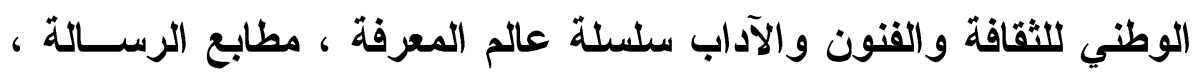

$$
\text { - م) } 9 \wedge \mathrm{V}
$$

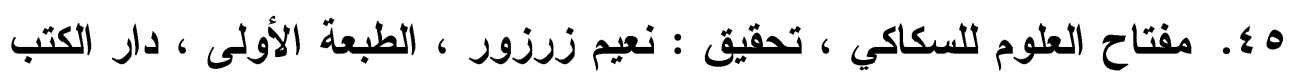

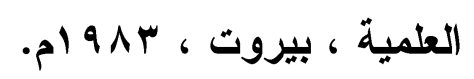

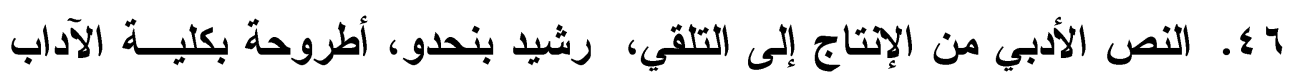

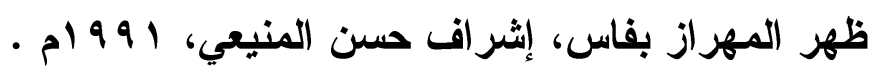

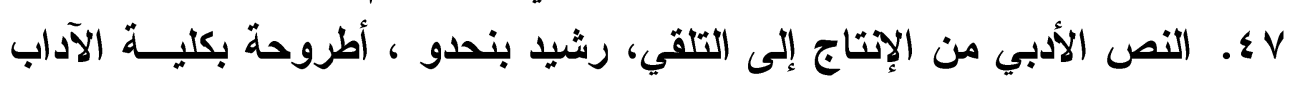

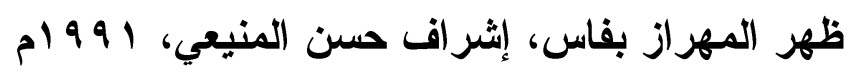

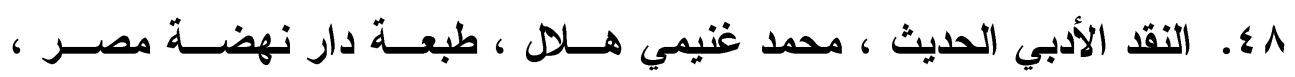

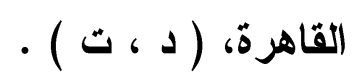


معنى المعنى خارج دائرة التمثيل البلاغي

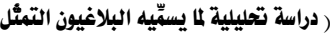
ومستتبعات التزاكيب )
(1 1 r r

العدد الخامس والعشروز للعام الrمr الجزء الثاني عشر

فهرس الموضوعهات

\begin{tabular}{|c|c|c|}
\hline |لصفمة & الإوضـوع & P \\
\hline 11910 & هلخص & -1 \\
\hline 11919 & Abstract & $-r$ \\
\hline $1191 \mathrm{~V}$ & هقدهة & $-r$ \\
\hline 1199. & المبحث الأول : الشهر بين الهدث والعديبث & $-\xi$ \\
\hline $1+\ldots 1$ & والتمثثيل البلاغي الثاني : تصوير المعنى بين دائرتي التمثل اللغـوي & -0 \\
\hline $\mid r \cdot r k$ & الخاتمة & -7 \\
\hline$|r \cdot r|$ & فهرس المصادر والمراجع : & $-v$ \\
\hline ir.ro & فهرس المرضوعات & $-\Lambda$ \\
\hline
\end{tabular}

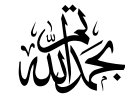

